\title{
ACTINOPTERYGIANS OF THE PERMIAN LOCALITY BUXIÈRES-LES-MINES (BOURBON- L'ARCHAMBAULT BASIN, FRANCE) AND THEIR RELATIONSHIP TO OTHER EARLY ACTINOPTERYGIANS
}

\author{
STANISLAV ŠTAMBERG \\ Museum of Eastern Bohemia in Hradec Králové, Eliščino nábřeží 465, 500 01 Hradec Králové, the Czech Republic; \\ e-mail: s.stamberg@muzeumhk.cz.
}

Štamberg, S. (2018): Actinopterygians of the Permian locality Buxières-les-Mines (Bourbon-l'Archambault Basin, France) and their relationship to other early actinopterygians. - Fossil Imprint, 74(3-4): 245-291, Praha. ISSN 2533-4050 (print), ISSN 2533-4069 (on-line).

\begin{abstract}
Actinopterygians from the large opencast coal mine in the vicinity of the village of Buxières-les-Mines (Bourbonl'Archambault Basin, Allier, France) are revisited and redescribed based on newly studied specimens. The understanding of the anatomy of Progyrolepis heyleri Poplin, 1999, originally described by Poplin (1999) on the basis of the upper and lower jaws only, is greatly enhanced and is relatively complete. The anatomy of the palatoquadrate, dermal bones of the skull roof, hyoid arch, operculum, suboperculum, shoulder girdle, cheek bones and branchiostegal rays is described. In addition, new observations have been made on changes in the shape of the maxilla during ontogenesis and microstructure of the teeth. Details of Progyrolepis heyleri scales, including their microstructure and morphology of the ridge scales are provided. The collection of whole individuals, body fragments and numerous isolated bones provide confirmation of the presence of Aeduella blainvillei which is the main component of the actinopterygian fauna in Buxières-les-Mines. Additional new knowledge was obtained regarding the great variability in bones of the opercular apparatus and maxilla, presence of the supraorbital, branchiostegal ray with a conspicuous hyoid process and the direction of mutual overlapping of the suboperculum and branchiostegal ray in Aeduella blainvillei (Agassiz, 1833). Microsculpture on the scales is redescribed in this species. Paramblypterus cf. duvernoy is the third member of the actinopterygians in the locality Buxières-les-Mines. Fragments of Paramblypterus are very rare and the bones of the skull roof are presented here. Anatomical features of Progyrolepis heyleri, Aeduella blainvillei and Paramblypterus cf. duvernoy were studied and compared with those of other Devonian and Permo-Carboniferous actinopterygians.
\end{abstract}

Key words: Actinopterygii, anatomy, Permian, Bourbon-l’Archambault Basin, French Massif Central

Received: May 28, 2018 | Accepted: December 3, 2018 | Issued: December 28, 2018

\section{Introduction}

The article brings together the results of study of the rich actinopterygian collection obtained from the locality Buxières-les-Mines. This research was carried out as collaboration between the Rhinopolis Association and the author of this paper. The actinopterygian fishes originate from the large opencast coal mine in the vicinity of the village of Buxières-les-Mines (Text-fig. 1). The mine, situated in the northern part of the Massif Central, Aumance Sub-basin of the Bourbon-l'Archambault Basin, was abandoned in 2001. Comprehensive palaeontological research was carried out in Buxières-les-Mines during the last ten years of the last century. Research work was organized by the Rhinopolis Association with great support from the mining company "Houilleres des bassins Centre et midi". A number of European geologists and palaeontologists participated in the research (Esçuillié et al. 1996), and a comprehensive collection of fossils was made (Text-fig. 2). A preliminary report on research in this locality was published by Steyer at al. (2000). The opencast mine exposed Suprabuxières Members of the Buxières Formation (Steyer et al. 2000) which are represented by the coal seams at the bottom of the quarry followed by lacustrine bituminous black shales with fauna remains. The Asselian age was estimated on the basis of the fauna (Steyer et al. 2000). Werneburg (2003) and Werneburg and Schneider (2006) dated the Buxières Formation to be Sakmarian based on the presence of the biozone Melanerpeton gracileDiscosauriscus pulcherrimus and Schneider and Werneburg (2006) considered the presence of the biozone Sysciophlebia alligans or Sysciophlebia n. sp. B to indicate an Asselian Sakmarian age. The beds containing the fauna were probably produced in a freshwater lacustrine environment (Steyer et al. 2000, Roscher and Schneider 2006). Schultze and Soler- 


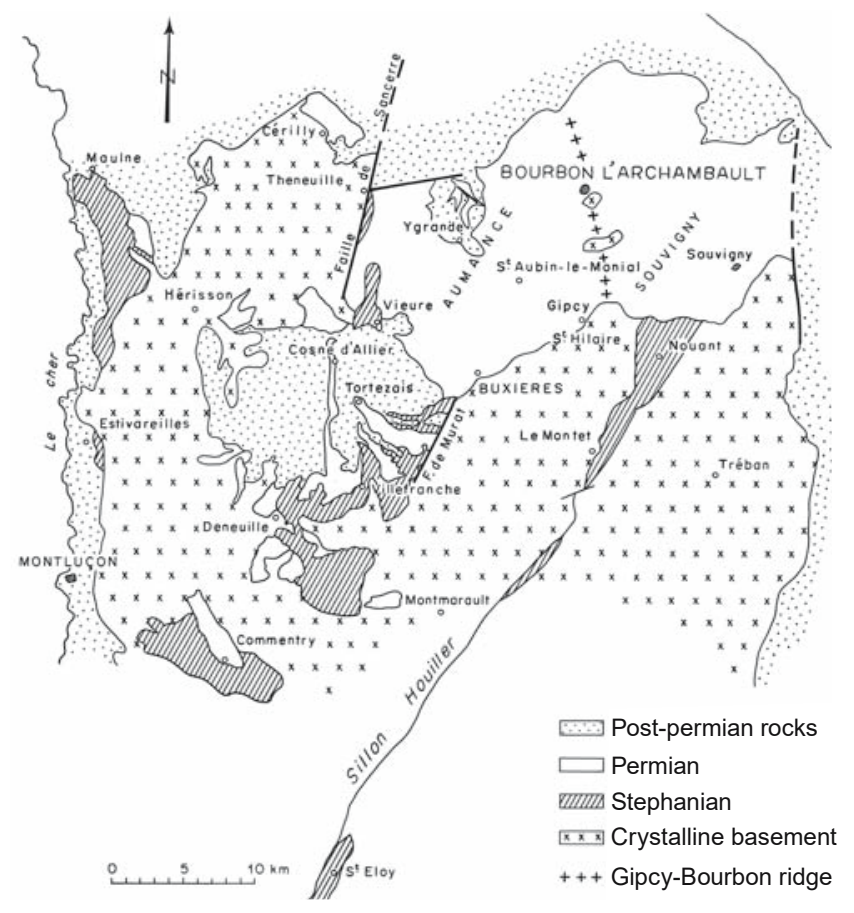

Text-fig. 1. Simplified geological map of the Permo-Carboniferous Bourbon-l'Archambault Basin. After Paquette and Feys (1989; modified).
Gijón (2004) however assume some marine influence on the environment, their assumption is based on a comparison of the fauna, suggesting an interconnection between the basins of the Massif Central and Bohemia through the Palaeotethys. Fischer et al. (2013) analysed oxygen and strontium isotopes from the shark teeth and spines of the Late Palaeozoic European basins and assumed the full adaptation of the sharks (Orthacanthus, Lissodus) from the black shales of the Buxières Formation to an obligate freshwater lifestyle.

Fauna and flora from Buxières-les-Mines and from the Basin Bourbon-l'Archambault were the subject of a number of research projects and an overview report was produced by Steyer et al. (2000). Actinopterygians from the Buxièresles-Mines and from the Basin Bourbon-l'Archambault are referred to in a series of papers by Daniel Heyler and Cécile Poplin. Heyler (1969) figured an isolated operculum, maxilla and cleithrum of Aeduellidae and indeterminable isolated sculptured scales. Heyler (1984) and Heyler and Poplin (1990) figured sculptured scales and bones with clear determination, the bones being from the opercular apparatus and skull roof of Paramblypterus and the skeletal fragments belonging within the range of Aeduella blainvillei (Agassiz, 1833). Poplin (1999) designated a new carnivorous actinopterygian fish Progyrolepis heyleri Poplin, 1999 based on the study of upper and lower jaws from Buxières-les-Mines. Heyler (2000) made a summary of actinopterygians from the Massif Central, and agreed with the determination of bones from Buxières-les-
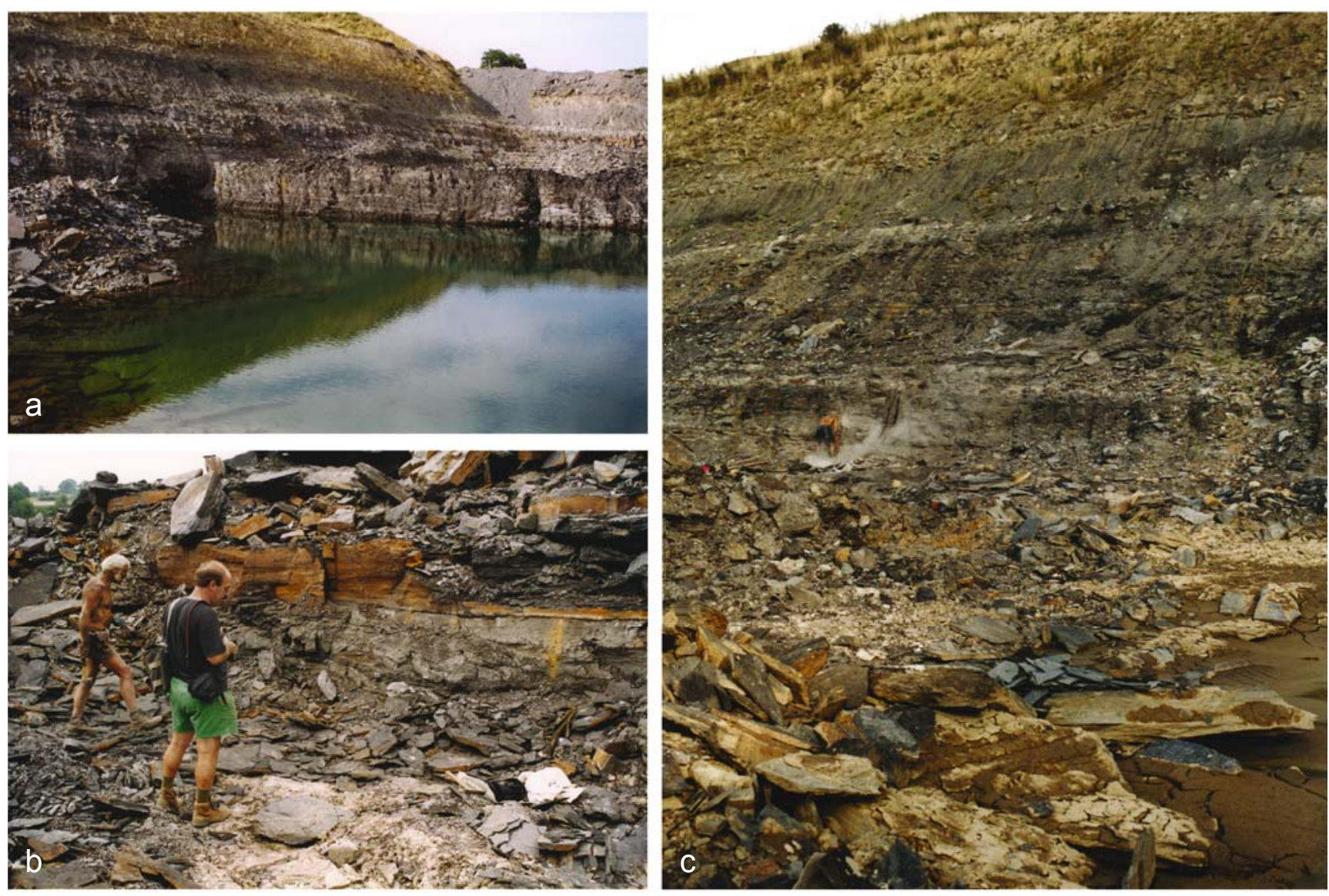

Text-fig. 2. Opencast coal mine in Buxières-les-Mines in the year 1999. a - flooded area after mining of coal seam. b - section of lacustrine bituminous black shales with fauna. $\mathrm{c}-\mathbf{3 0} \mathrm{m}$ thick section of lacustrine bituminous black shales, fluvial clastics and channel sandstones in the mine. 


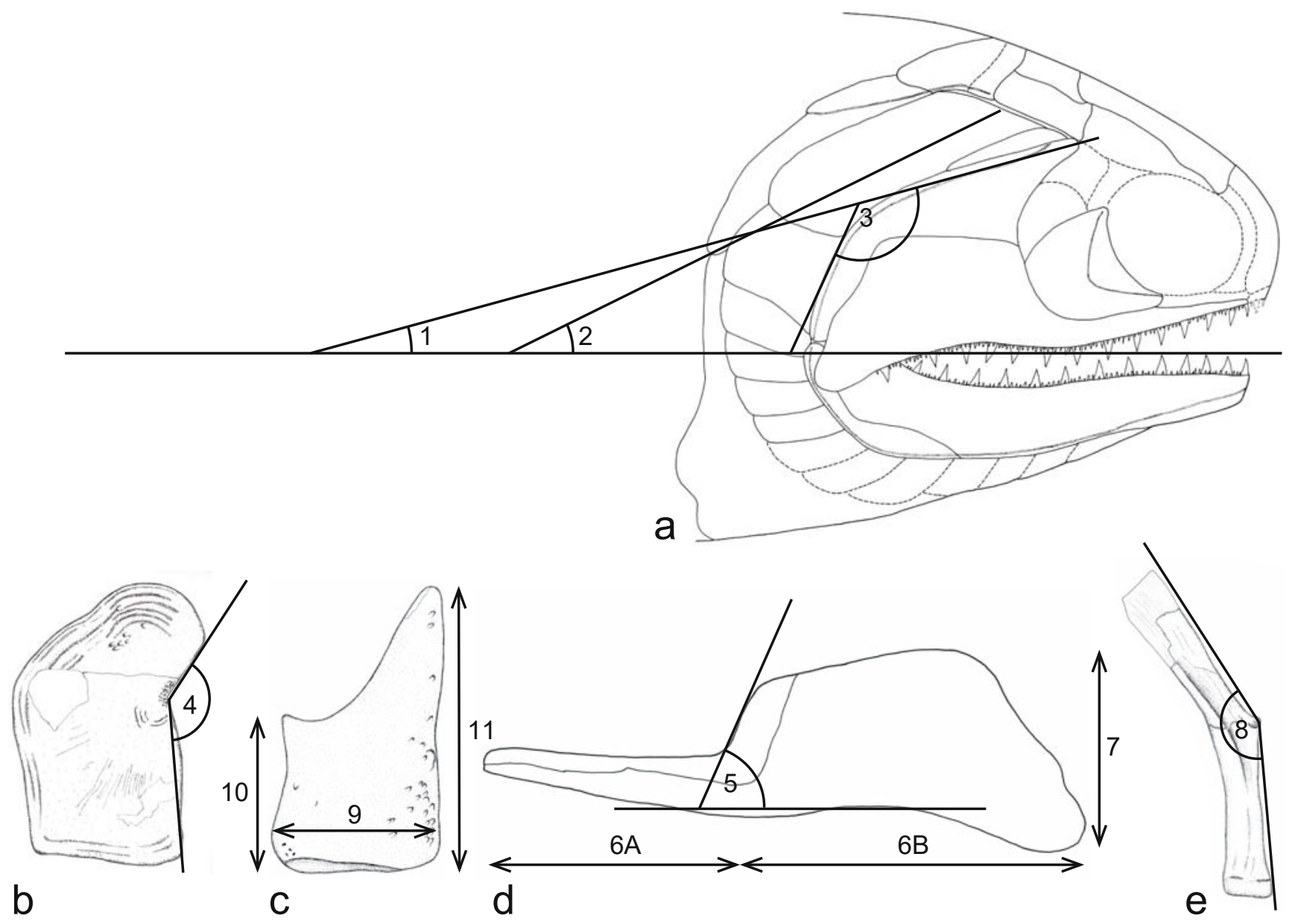

Text-fig. 3. Methods of measurement of the angles and dimensions of some bones. a - measurements on the skull: 1 - angle formed by posterodorsal margin of the preoperculum and the body axis; 2 - angle of inclination of the operculum to the axis of the body; 3 angle of bend formedby dorso-posterior margin of the anterior branch of the preoperculum with the posterior margin of the ventral branch of the preoperculum. b - operculum of Aeduella blainvillei: 4 - angle of bend formed by the anterior margins of the dorsal and ventral branches of the operculum. $\mathrm{c}$ - suboperculum of Aeduella blainvillei: 9 - length of the suboperculum; 10 - depth of the suboperculum along its anterior margin; 11 - depth of the suboperculum along its posterior margin. $d$ - measurements of the maxilla: 5 - angle made by the anterior margin of the maxillary plate with the denticulated inferior margin of the maxillary; 6A - length of the maxillary plate; $6 \mathrm{~B}$ - length of the narrow anterior part of the maxillary; 7 - depth of the maxillary plate. $\mathrm{e}$ - measurement of hyomandibula: 8 - angle of bend of the hyomandibula formed by the dorsal and ventral parts of the hyomandibula.

Mines as Progyrolepis heyleri Poplin, 1999, Paramblypterus sp. and also the presence of aeduellids. Complete specimens, skeletal fragments and isolated bones of aeduellids from Buxières-les-Mines have been described several times in the past by Heyler (1969, 1984, 2000), Heyler and Poplin (1990) and Steyer et al. (2000). It has always been stated that they are similar to Aeduella blainvillei. Heyler (2000) noted a great similarity to Aeduella blainvillei, but pointed out the differences in the shape of the operculum and upper jaw. Heyler (2000) considered in particular differences in the shape of the maxilla and operculum to be so great that he recommended establishing a new genus and species, "Decazella buxieri" for the aeduellids from Buxières-les-Mines.

\section{Material and methods}

A large amount of actinopterygian skeletal fragments were collected during the course of research work in the locality Buxières-les-Mines. Decomposed bodies with isolated bones and scales form the bulk of the specimens. Moreover the bones and scales of different species are mixed together with abundant scales and body fragments of acanthodians of the genus Acanthodes. Integrated parts of the skull or bodies of the genus Progyrolepis are very rare, more common are whole bodies of aeduellids particularly of juvenile specimens. About 200 specimens suitable for study were selected from the comprehensive collection from Buxières-les-Mines and their identification numbers are given in the text and in the explanation of the figures. Bones of different individuals frequently occur in one sample. Some specimens were prepared using a Krantz pneumatic needle. Photographs were prepared using a Canon EOS 400D camera, and most of the samples were whitened with ammonium chloride for both the photographing and drawings. Suitable scales and microsculpture of scales and teeth were documented using a Hitachi S-3700N SEM. Drawings were prepared using a SM 20 stereomicroscope with camera lucida. The descriptive terminology conforms 
to that adopted by Grande and Bemis (1998) with the inclusion of some terms after Gardiner (1984) and Poplin and Lund (1997). The terms frontal and parietal are used in the traditional sense rather than the skull roof terminology based on homology (parietal and postparietal). Methods of skull bone measurements of the skull are schematically figured in Text-fig. 3. The numbers of the scale count were determinate, as far as possible, by counting the number of scales along the lateral sensory line. The number in numerator means the number of scale rows dividing the supracleithrum from the anterior margin of the base of the dorsal fin. The first number in denominator means the number of scale rows between the supracleithrum and the anterior margin of the pelvic fin base; the second one is the number of scale rows between the supracleithrum and the anal fin base; the third one is the number of scale rows between the supracleithrum and the caudal fin base. The final number represents the total number of scale rows from the supracleithrum to the point of which the dorsal lobe of the caudal fin ascends (i. e. where the scales change their direction).

\section{Institutional abbreviations}

D, BX, BXM - Association Rhinopolis, Gannat, France

BUX - Laboratoire de Paléontologie, Muséum National d'Histoire Naturelle, Paris, France

MHK, G - Museum of Eastern Bohemia in Hradec Králové, the Czech Republic

\section{Systematic palaeontology}

\section{Subclass Actinopterygii Cope, 1877 Family Acrolepidae ALdinger, 1937}

Kazanceva-Selezneva (1977) published a new definition of the family Palaeoniscidae and classified Progyrolepis to this family. Štamberg (1991) and Poplin (1999) placed Progyrolepis into the family Pygopteridae Aldinger, 1937. The distribution of the cheek bones and in particular the opercular apparatus place Progyrolepis in the family Pygopteridae, but the shape of the parasphenoid and curved interfrontal suture do not fit in the original description of Pygopteridae submitted by Aldinger (1937). The presence of conical teeth and antoperculum in Progyrolepis heyleri exclude this species from the family Palaeoniscidae in the sense of Kazanceva-Selezneva (1977). The genus Progyrolepis is provisionally included here to the family Acrolepidae AldingER, 1937 because characters in this genus best match the definition presented by Aldinger (1937).

\section{Genus Progyrolepis FritsCH, 1895}

Ty pe species. Progyrolepis speciosus (FrIČ, 1875)

In cluded s pecies. Progyrolepis speciosus (Frič, 1875); P. heyleri Poplin, 1999

Geologic and geographic distribution. Upper Carboniferous - Lower Permian, Bourbonl'Archambault Basin (France), Puertollano Basin (Spain); Central and West Bohemian Late Palaeozoic basins and Krkonoše Piedmont Basin (the Czech Republic).
D i a gn o s i s. After Štamberg (1991; here modified). Carnivorous fish reaching $60-70 \mathrm{~cm}$ in total length. Anterior lepidiotrichia of the pectoral fin unjointed proximally, distally articulated and dichotomously branched. Endocranium ossified. Frontal is 2.5 times longer than wide with sculpture formed by tubercles. Rostral region of the head is conspicuously convex anteriorly, comprising a large single postrostral, paired nasal and denticulated rostropremaxilla. The medial side of the palatoquadrate is formed by the entopterygoid, ectopterygoid, dermometapterygoid and small dermopalatines. The maxilla has a long maxillary plate that is trapezoidal in shape with an outstanding process ventroposteriorly. The length - height ratio of the maxillary plate is $1.6-2$. The length of the maxilla is 1.6 to 1.9 times that of the maxillary plate length. The maxillary plate bears outstanding sculpture formed by vermicularly curved ridges. Tubercles prevail along the ventral border and on the anterior suborbital part of the maxilla. The large anterior region of the maxillary plate is without sculpture and is overlapped by a large jugal. The lower jaw is very stout. The teeth on the jaws are arranged in two rows in which the outer row consists of numerous small sharply pointed teeth whereas a small number of large conical laniaries form the inner row. The preoperculum is conspicuously bent at an angle of $130^{\circ}$, and inclined anteriorly. The orbit is small and located anteriorly. The operculum is of oval or oblong shape, three times deeper than it is long and 2.5 times deeper than the depth of the quadrate suboperculum. An antoperculum or epipraeoperculum may be present. Numerous branchiostegal rays. Stout rhomboidal scales with conspicuous sculpture formed by ridges which diagonally traverse across the scale and terminate in denticulation posteriorly.

\section{Progyrolepis heyleri PoPLIN, 1999 Text-figs 4-24}

1999 Progyrolepis heyleri n. sp.; Poplin, p. 148-154, figs 1-6. 2000 Progyrolepis heyleri; Steyer et al., pl. I, fig. C. 2016b Progyrolepis heyleri Poplin, 1999; Štamberg, figs 5-7.

Diagnosis. After Poplin (1999; here completed). Large carnivorous fish reaching $70 \mathrm{~cm}$ in total length with maxillaries and mandibles reaching $10 \mathrm{~cm}$ in length. The maxillary plate is trapezoidal in shape and lowers anteriorly than posteriorly, and longer than the narrow anterior suborbital part of the maxilla. The maxillary plate bears outstanding sculpture formed by vermicularly curved ridges; tubercles prevail along the ventral border and on the anterior suborbital part of the maxilla. The plate is without sculpture anteriorly, and it is overlapped by the very large jugal. Similarly, the smooth dorsal border of the narrow suborbital part of the maxilla is overlapped by the lachrymal. The anterior border of the maxillary plate is relatively steep and in adult specimens makes an angle of about $70^{\circ}$ with the denticulated inferior margin of the maxilla. Laniary conical teeth are large and the ratio of tooth height to head depth at the front of the opercular series is about 22. The teeth have an acrodin apex and fine microsculpture formed by tiny protuberances distributed over the surface of the tooth around the acrodin apex. The elliptical protuberances are proximodistally elongated, separated from each other and only rarely in contact. The hyomandibula, conspicuously anteriorly 

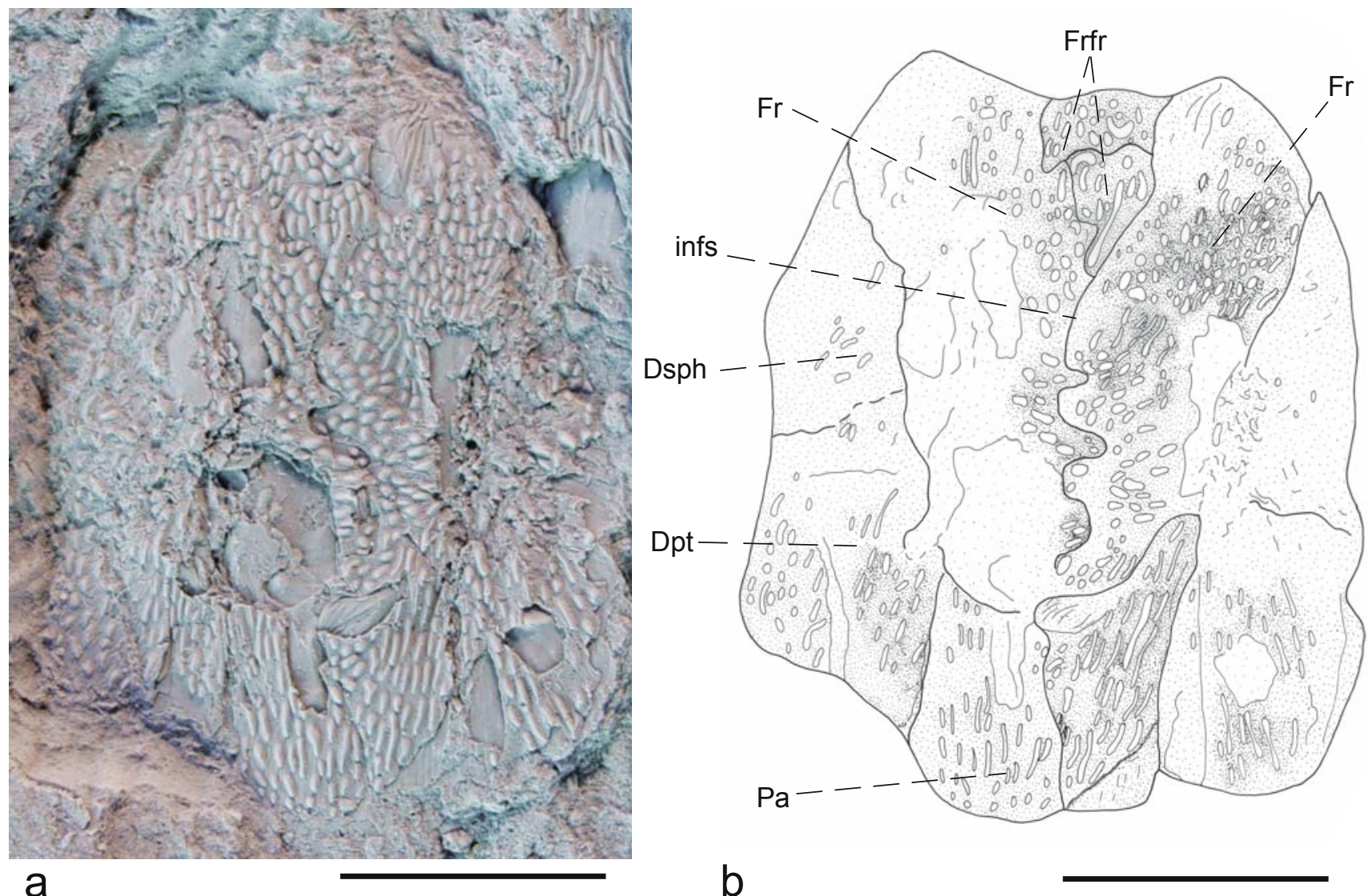

b

Text-fig. 4. Progyrolepis heyleri PoPLIN, 1999. The skull roof in dorsal view. MHK 82834. Scale bars 5 mm. a - photograph, whitened. b - drawing. Abbreviations: Dsph - dermosphenotic; Dpt - dermopterotic; Fr - frontal; Frfr - frontal fragments; infs interfrontal suture; $\mathbf{P a}$ - parietal.

inclined, consists of two clearly distinct arms forming an angle of $151-157^{\circ}$. The dorsoanterior arm is the wider. The processus opercularis is well developed. The preoperculum is without sculpture anteriorly, inclined in an anterior direction and forms an angle of $15^{\circ}$ with the anteroposterior axis of the body. The operculum is oblong in shape and does not narrow ventrally. The narrow antoperculum borders the dorsal third of the anterior border of the operculum. The suboperculum is of quadrilateral shape projecting anteriorly as in dorsal as ventral directions. The anterior border of the supracleithrum is straight in its dorsal two thirds, but the ventral one third is conspicuously concave and considerably narrowed. Stout rhomboidal shaped scales bear conspicuous sculpture formed by ridges diagonally traversing across the scale to terminate in denticulation posteriorly.

D e s c ri p t i o n. Body form. The referred skeletal and body fragments represent a carnivorous species reaching up to $70 \mathrm{~cm}$ in total body length. The slender body is covered with sculptured scales and the skull length is approximately $20 \%$ the total body length.

Rostral part and skull roof. The rostral area has a convex outline in an anterior direction as demonstrated by specimen BX 11.11.97. However, the individual bones of the rostral region are not satisfactorily preserved in any of the other studied specimens. Although the bones of the skull roof are mostly isolated, partial complexes of the frontal, parietal, dermosphenotic and dermopterotic are preserved (D 11.11.95.7; D 08.02.98.50; MHK 82834). The frontal
(Text-figs 4, 5) is oblong in shape and elongated in an anteroposterior direction, with length 2.5 times the width. The interfrontal suture is significantly curved and forms two processes which fit into depressions on the opposite frontal bone. The lateral edge of the frontal lacks processes, and contacts the dermosphenotic and dermopterotic slightly in the posterior region. The frontal is posteriorly adjacent to the parietal which is 2.5 times shorter than the frontal, and is slightly elongated in an anteroposterior direction (Textfig. 4). Similar to Elonichthys germari GieBel, 1848, the total width of the posterior part of the median part of the skull roof (i.e. right and left parietals) is clearly smaller than the width of the anterior part (i.e. right and left frontals) (Schindler 2018a). The triangular dermosphenotic borders the frontal laterally. The oblong dermopterotic borders the posterior region of the frontal and entire lateral edge of the parietal laterally (Text-fig. 4). The border between the dermosphenotic and dermopterotic is located anteriad to the border between the frontal and the parietal. Some fishes of the family Elonichthyidae Aldinger, 1937 have the dermosphenotic-dermopterotic borderline posteriorly to the contact between the frontal and the parietal, as illustrated by Schindler (2018b) in Rhabdolepis macropterus (BRONN, 1829) and Štamberg (2010a) in Elonichthys krejcii (FRITSCH, $1895)$ or the dermosphenotic-dermopterotic borderline is almost anteriad to the borderline between the frontal-parietal as figured by Schindler $(2017,2018 \mathrm{a})$ in Elonichthys fritschi FrIEDRICH, 1878 and Elonichthys germari GIEBEL, 1848. 


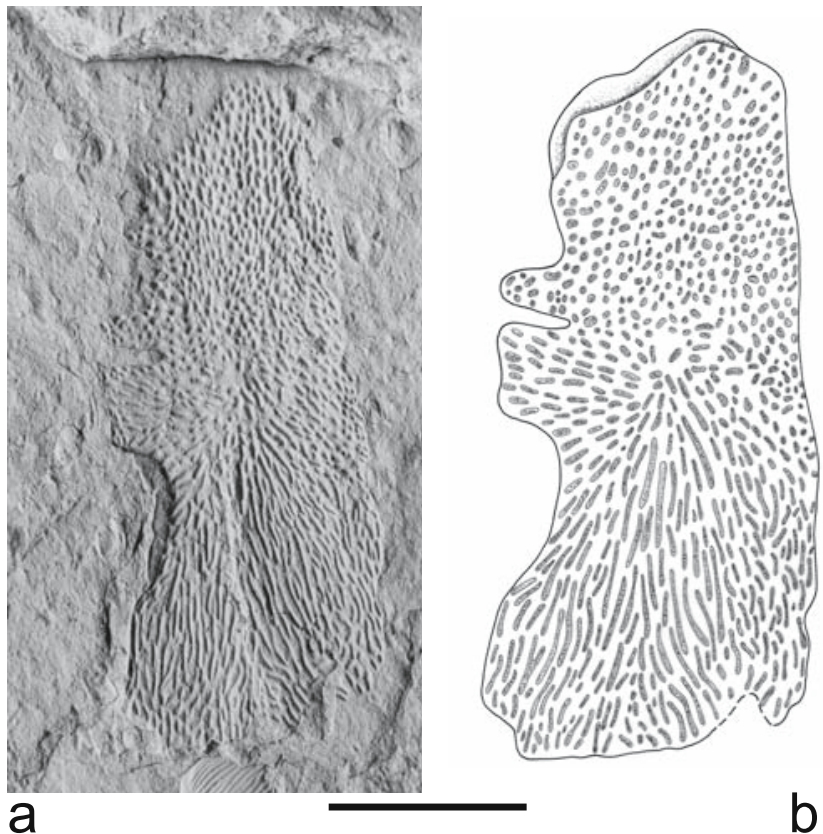

Text-fig. 5. Progyrolepis heyleri PopLIN, 1999. Isolated right frontal in dorsal view. Specimen D 08.02.98.50. Scale bar 5 mm. a - photograph, whitened. $b$ - drawing.

The exposed part of the skull roof bones are covered by conspicuous sculpture. The sculpture on the anterior half of the frontal consists of tubercles or very short ridges. The welldeveloped ridges prevail in the posterior half of the bone, and they diverge radially from the radiation centre of the frontal which lies approximately at equal distance from the anterior and posterior borders of the bone. A narrow strip of the frontal anterior margin is overlapped by the posterior part of the postrostral (Text-fig. 5). The young specimen MHK 82834 exhibits two small bones inserted between the anterior part of the right and left frontals. These two bones are bordered by the right and left frontals, and they are characterised by different sculpture on the frontals in this area (Text-fig. 4). They are not developed in any other studied skull roof, and I believe these bones are formed from fragmentation of the frontals, and they developed only by chance in this young specimen. This is distinct from the arrangement of small bones in the centre line of the anterior region of the parietals (frontals in the sense used herein) in Cheirolepis canadensis Whiteaves, 1881 which were described as posterior postrostrals by Arratia and Cloutier (1996).

Significant sculpture consisting of short ridges and tubercles also covers other bones in the skull roof (Text-fig. 4 ), and completely conceals the pores of the sensory canals. Sculpture on these bones is also well developed in young specimens.

The same shape and sculpture of the skull roof bones is demonstrated in the specimen BUX 4a figured by Heyler (1984: fig. 8b) and Heyler and Poplin (1990: fig. 5). The figured specimen shows the frontals, parietals and left dermosphenotic of triangular shape, but not the postrostral as is stated in the associated explanations of Heyler (1984) and Heyler and Poplin (1990).

Parasphenoid. The isolated parasphenoid in specimen D 07.11.95.10 exhibits a three lobed bone (Text-fig. 6). The anterior lobe creates the middle corpus parasphenoidis which extends in a postero-lateral direction as paired processus ascendens posterior. The centre of ossification is situated in the posterior third of the corpus parasphenoidis, and it lies at the intersection of the axes of these lobes. The
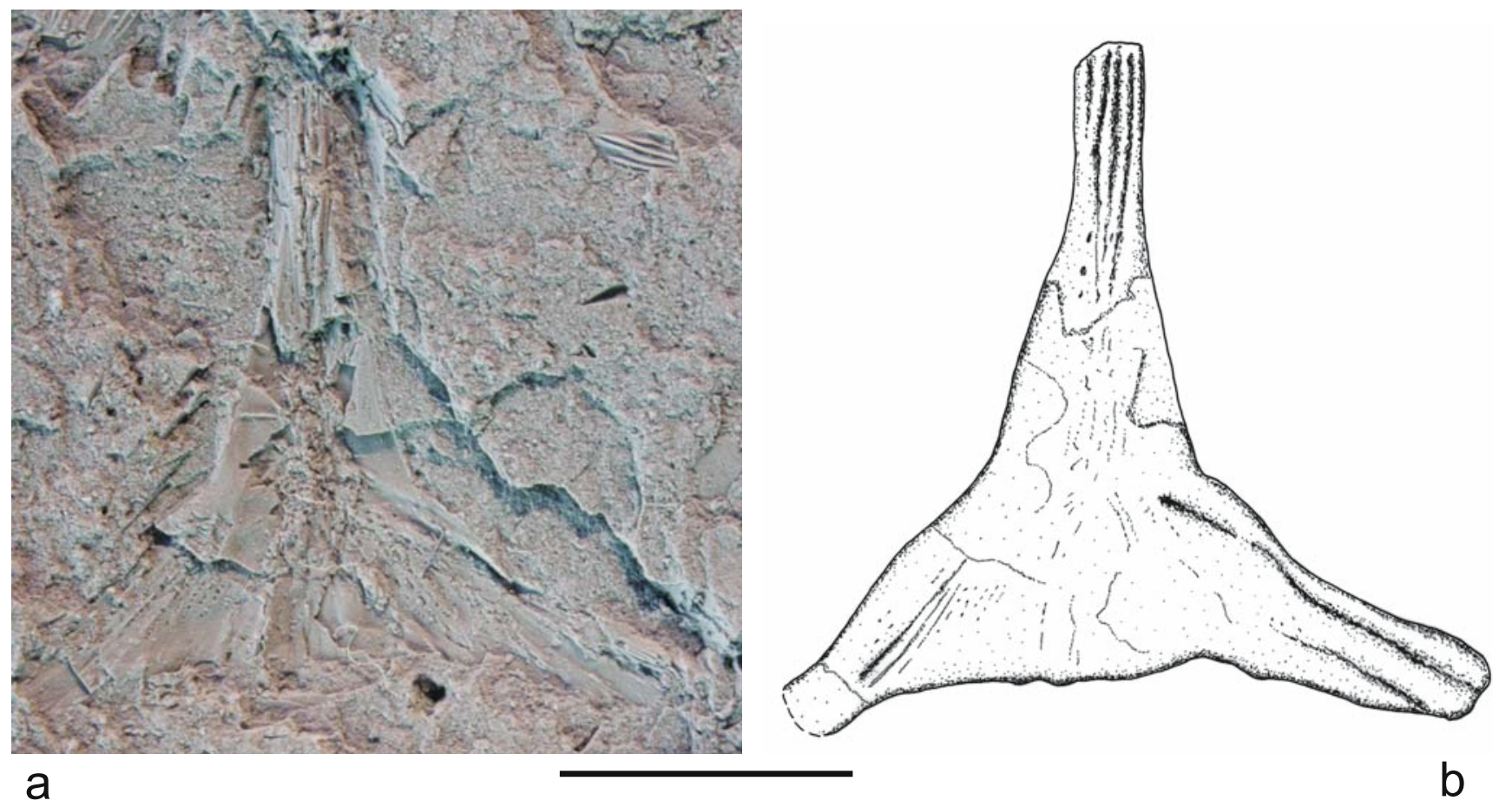

a

Text-fig. 6. Progyrolepis heyleri PopLin, 1999. Parasphenoid in ventral view. D 07.11.95.10. Scale bar 5 mm. a - photograph. Granulation in the medial region of the corpus parasphenoidis and in the proximal part of the processus ascendens are the remains of the dentition on the ventral side of the parasphenoid. $b$ - drawing. 


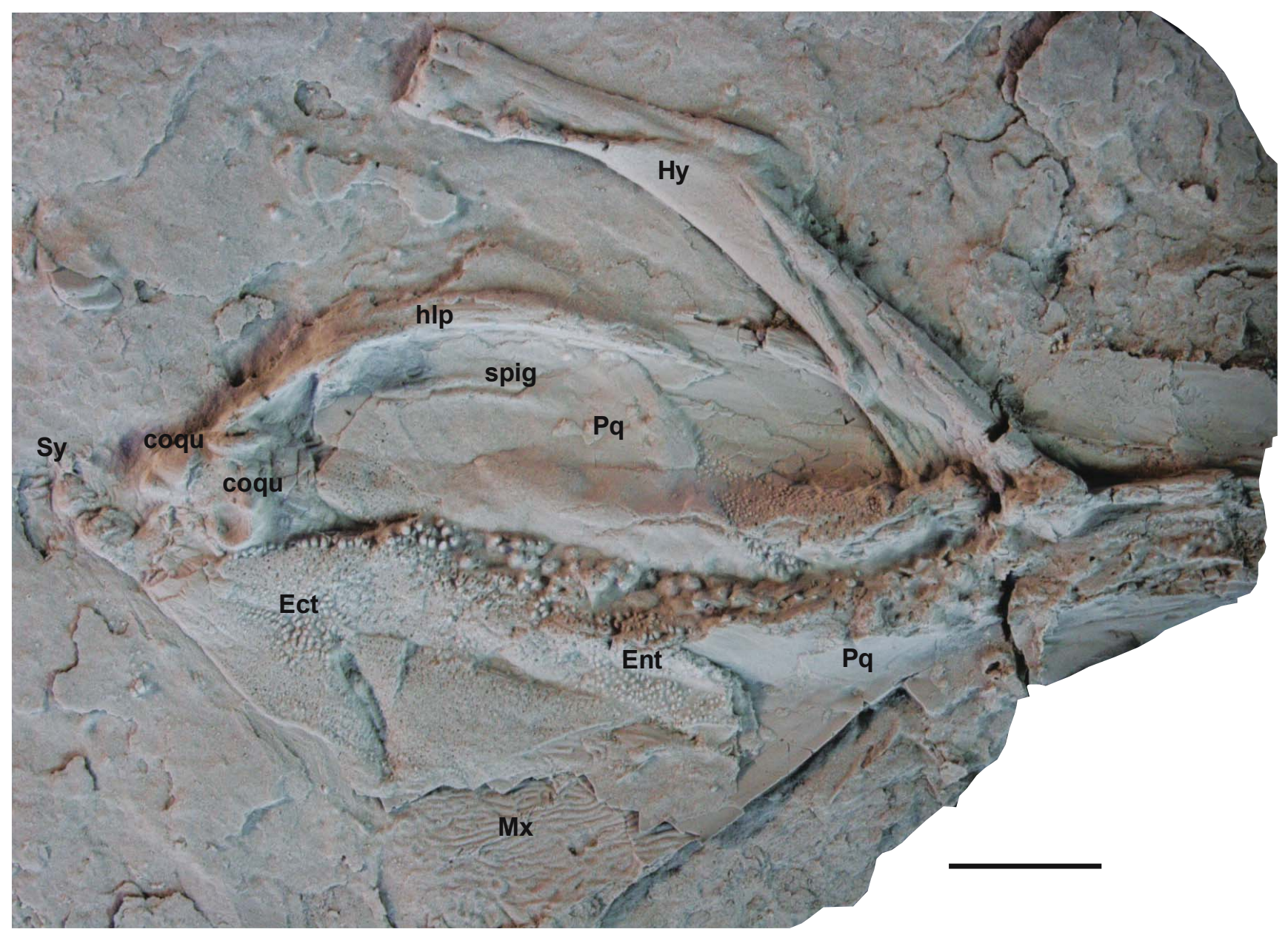

Text-fig. 7. Progyrolepis heyleri Poplin, 1999. Left palatomaxillary apparatus in medial view. The hyomandibula above, the entopterygoid and the ectopterygoid demonstrate shagreen-like cover with small teeth. BX 12.05.98.5, whitened. Scale bar 5 mm. Abbreviations: coqu - condyles on the quadratum; Ect - ectopterygoid; Ent - entopterygoid; Hy - hyomandibula; hlp - horizontal lamina of preoperculum; Mx - maxilla; Pq - palatoquadrate; spig - spiracular groove; Sy - symplectic.

corpus parasphenoidis tapers significantly and narrows in a forward direction. On the contrary it extends smoothly backwards to become the paired processus ascendens posterior which narrows distally, and forms an angle of $68^{\circ}$ with the corpus parasphenoidis. The posterior border of the corpus parasphenoidis is slightly convex but it does not extend posteriorly. Granulation in the posterior region of the bone in the counterparts of D 07.11.95.10 indicates dentition on the ventral surface of the corpus parasphenoidis (Text-fig. 6). The shape of the parasphenoid, including the angle of the processus ascendens direction is similar to the parasphenoid of Elonichthys crassidens Giebel, 1848 (personal observation).

Palatoquadrate and dermal bones of the cheek. The palatoquadrate is ossified as a single bone and its division into the pars quadratum, pars metapterygoidea and pars autopalatina is only arbitrary because the suturing of these individual parts is unclear. The palatoquadrate (Text-figs 7 , 17 ) is conspicuously thickened in the pars quadratum area and on the posteroventral edge two condyles were developed for articulation of the palatoquadrate with the lower jaw. There is neither a hole or processes on the pars metapterygoidea as figured by Pearson and Westoll (1979) in Cheirolepis traili Agassiz, 1835, Watson (1928: fig. 7) in Nematoptychius greennocki (TraquaIR, 1866), Gardiner
(1984: figs 56, 58) in Mimipiscis toombsi (GARDINER and BARTRAM, 1977) and Moythomasia durgaringa GARDINER and Bartram, 1977, or Nielsen (1942: fig. 35) in Pteronisculus magnus (Nielsen, 1942). The medial surface of the palatoquadrate in the pars metapterygoidea exhibits a small groove (spig) which traverses arcuately close to the dorsal margin of the bone (Text-fig. 7). This groove may represent a similar structure in Pteronisculus magnus as described by Nielsen (1942: fig. 36) or Mimipiscis toombsi and Moythomasia durgaringa figured by Gardiner (1984: figs $56,58)$. Gardiner (1984) assumed it was the lateral surface of the ventral end of the spiracular diverticulum. Three dermal bones are associated with the medial side of the palatoquadrate. Laterally the palatoquadrate is covered by the maxilla, quadratojugal and partly by the preoperculum.

The ectopterygoid is an anteroposteriorly elongated bone (BX 12.05.98.5; D 08.02.98.10.4/4; D 14.03.97.10; D 14.03.98.19.6/6) which covers the medial side of the palatoquadrate posteroventrally (Text-figs 7-9). It extends from the most posterior part of the palatoquadrate where it has a vertical position and binds to the palatoquadrate at the location of the adductor fossa. Immediately anteriorly to the adductor opening is the ectopterygoid bend and it forms a ventral horizontal lamina where the vertical lamina continues in an anterior direction. The vertical lamina is 


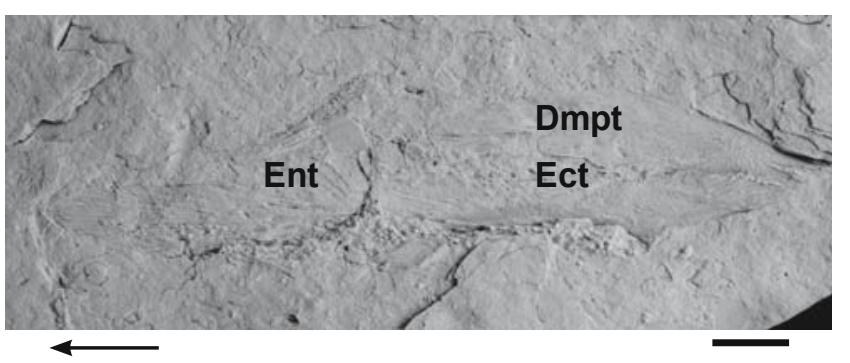

Text-fig. 8. Progyrolepis heyleri Poplin, 1999. Outprint of the left entopterygoid, ectopterygoid and dermometapterygoid in lateral view. D 14.03.98.19.6/6, whitened. Arrow indicates directio cranialis. Scale bar $5 \mathrm{~mm}$. Abbreviations: Dmpt dermometapterygoid; Ect-ectopterygoid; Ent-entopterygoid.

deepest midlength and conspicuously narrower anteriorly. The horizontal lamina (Text-fig. 9) sutures laterally with the horizontal lamina of the maxilla. The ectopterygoid bears small teeth covering the entire medial surface of the bone. The teeth on the horizontal lamina are sharply pointed (Text-fig. $9 b$ ), identical in size with the smaller marginal teeth forming the outer row on the jaw. The teeth covering the dorsal region of the medial surface are much smaller. The ectopterygoid is bordered dorsally by the dermometapterygoid.

The dermometapterygoid covers the medial side of the palatoquadrate in the pars metapterygoidea. Here, the dermometapterygoid is considered to be a separate bone and not just a denticulated part of the pars metapterygoidea (Arratia and Schultze 1991). The dermometapterygoid (Text-fig. 8) begins at the posterior end of the palatoquadrate, dorsally borders the ectopterygoid and narrows anteriorly, and does not reach the position from which the anterior part of the maxillary plate begins to broaden. The radiation centre of the metapterygoid lies in the posterior region of the bone near its dorso-posterion margin. The dermometapterygoid is one bone which corresponds in its shape and position with that figured by Nielsen (1942: fig. 37) in Pteronisculus aldingeri (NIELSEN, 1942) or Gardiner (1963) in Rhabdolepis saarbrueckensis GARDINER, 1963 in contrast to Mimipiscis toombsi where there are four dermometapterygoids (Gardiner 1984) in the pars metapterygoidea.

The entopterygoid in the sense of Arratia and Schultze (1991), covers medially a large portion of the palatal region of the pars autopalatina. The entopterygoid (Text-figs 7,8) is posteriorly in contact with the ectopterygoid as in Mimipiscis toombsi (Gardiner 1984) and sutured dorsoposteriorly with the dermometapterygoid. The bone is approximately triangular in outline, it is extended in an anteroposterior direction and it increases in depth posteriorly where it is in contact with the ectopterygoid and dermometapterygoid. The entopterygoid is bent laterally along its ventral margin forming the horizontal lamina which continues up to the horizontal lamina of the ectopterygoid. The horizontal lamina and medial surface of the entopterygoid are densely covered with small teeth (Text-fig. 7). The centre of ossification of the entopterygoid lies on its posterior margin, and its location is different to that in Pteronisculus aldingeri and Mimipiscis toombsi where the centre of ossification of the entopterygoid lies close to the dorsal margin of the bone (Nielsen 1942, Gardiner 1984).
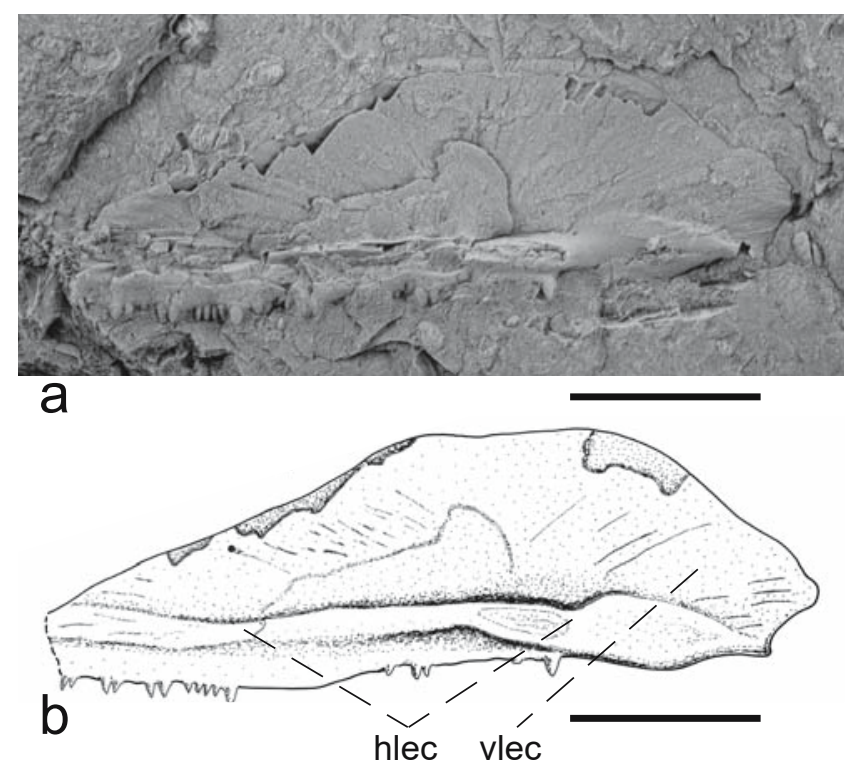

Tex-fig. 9. Progyrolepis heyleri Poptin, 1999. Left ectopterygoid in lateral view with the horizontal lamina which bears the teeth. D 08.02.98.10.4/4, Scale bars $5 \mathrm{~mm}$. a - photograph, whitened. b - drawing. Abbreviations: hlec - horizontal lamina of ectopterygoig; vlec - vertical lamina of ectopterygoid.

The presence of the dermopalatinal bones is obscure. This region is not well preserved on the palatoquadrate. Specimen D 08.02.98.10.4/4 exhibits an ectopterygoid with a well-developed horizontal lamina (Text-fig. 9) reaching up to the anterior margin of the ectopterygoid.

Maxilla. The shape, sculpture, and dentition of the maxilla were considered by Poplin (1999) to be essential in the designation of the new species Progyrolepis heyleri. The newly studied material contains numerous specimens with not only a well preserved maxilla with these defining features, but also the whole palatoquadrate complex including its dermal bones. The maxillary bones from different ontogenetic stages are also preserved, ranging from the small $18 \mathrm{~mm}$ long maxilla representing young specimens of $140 \mathrm{~mm}$ total body length (D 11.11.95.7) to the $97 \mathrm{~mm}$ length maxilla (BX 17.10.98.2). The maxilla consists of a narrow anterior suborbital part and a conspicuously deep maxillary plate continuing backwards (Text-figs 10,11). The maxillary plate is relatively low and long. The length of the maxilla is from 1.6 to 1.9 times that of the maxillary plate, and it is clear that the narrow suborbital part of the maxilla is shorter than the length of the maxillary plate. The juvenile specimen (D 13.04.97.6) has an anterior maxillary suborbital part that is less pronounced and slightly longer than in older specimens in comparison to the maxillary plate, with the length being almost the same as that of the maxillary plate (Text-fig. 11b, c). The adult specimen (D 04.10.98.5) on the contrary has a strongly pronounced anterior suborbital part which is conspicuously shorter than the length of the maxillary plate (Text-figs 10a, 11a). The maxillary plate is trapezoidal in shape and deeper posteriorly than anteriorly. The posterior margin is oblique, and slightly concaves (Text-fig. 10a-d). The maxillary plate is ventroposteriorly extended into a strongly pronounced process. The ratio of the maxillary plate length to its greatest depth, including the 

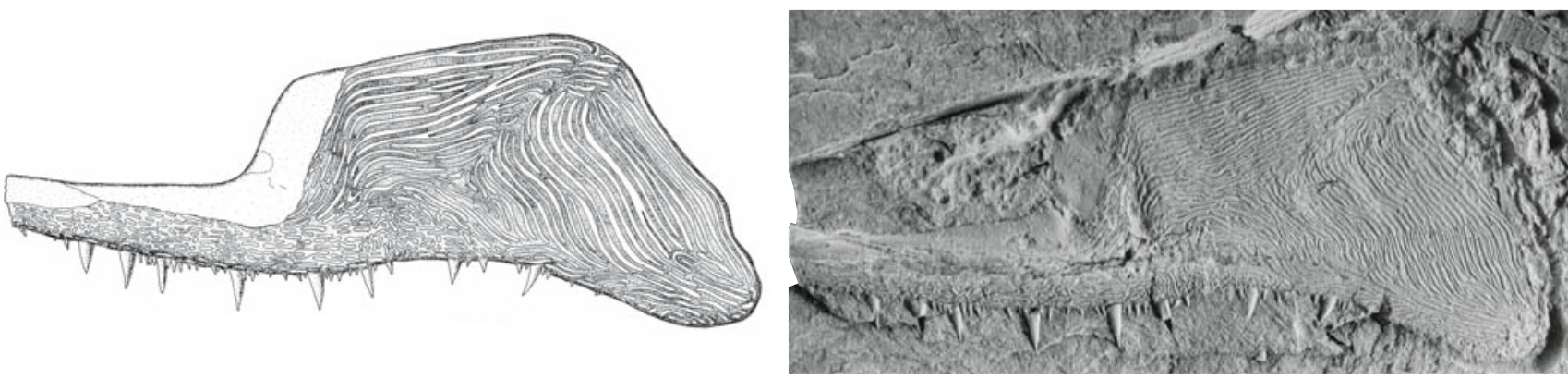

a

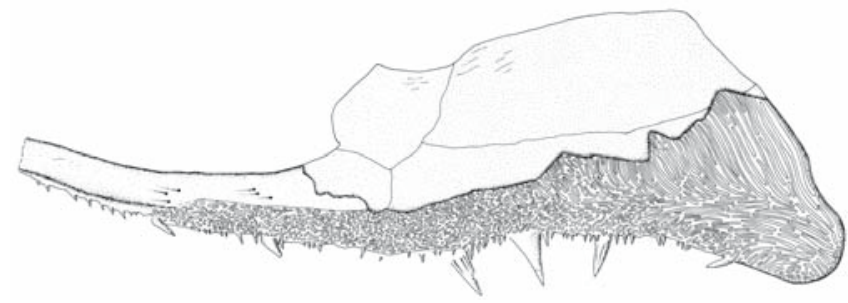

C

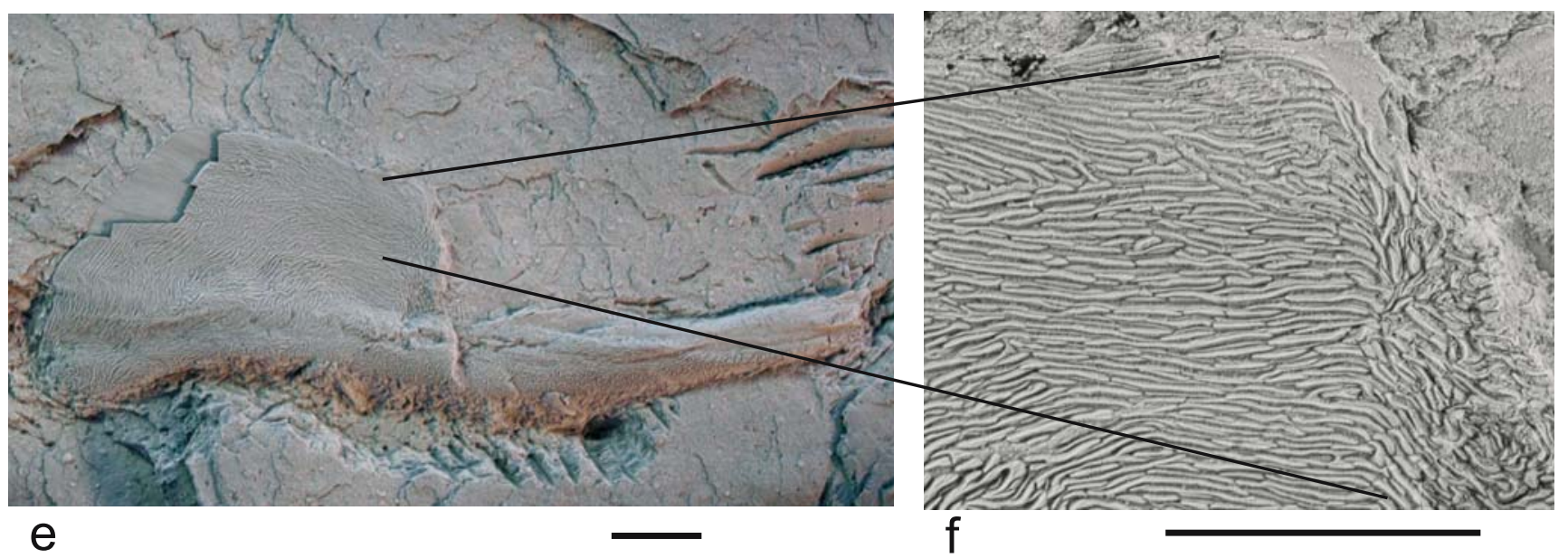

Text-fig. 10. Progyrolepis heyleri Poplin, 1999. a, b - drawing and photograph of the left maxilla in lateral view. D 23.08.98.5. Scale bars $5 \mathrm{~mm}$. c - drawing of the left maxilla in lateral view. D 06.03.96.1. Scale bar $5 \mathrm{~mm}$. $\mathrm{d}$ - right maxilla in lateral view. BX 17.10.98.2, whitened. Scale bar $5 \mathrm{~mm}$. e, $\mathrm{f}$ - left maxilla in lateral view with detail of the sculpture on the anterior region of the maxillary plate (f). D 11.11.95.17, whitened. Scale bars 5 mm.

ventroposterior process, is 1.6-2.0. The anterior margin of the plate in older specimens is relatively steep compared to the denticulated inferior margin of the maxillary, and it produces an angle of $70-77^{\circ}$ (Text-figs 10a-d, 11a). The anterior margin of the maxillary plate in young specimens is not so steep, and the angle is approximately $40^{\circ}$ (Textfig. 11b, c). A conspicuous horizontal lamina (hlm) traverses along the ventral border of the maxilla on its medial side (Text-fig. 11b, c). The horizontal lamina begins on the ventral margin of the maxilla, at approximately one third of the maxillary plate length. The horizontal lamina increases anteriorly in width and is stouter. The horizontal lamina bears a row of small teeth laterally and large carnivorous teeth medially. The horizontal lamina of the maxilla is medially in contact with the horizontal lamina of the ectopterygoid.

The maxilla bears outstanding sculpture on its lateral surface. The type of sculpture varies according to the position on the maxilla. The narrow anterior suborbital part of the maxilla bears tubercles and short ridges arranged predominantly in an anteroposterior direction. The maxillary plate exhibits predominantly long ridges parallel to the posterior, anterior and dorsal margins of the bone. The maxillary plate of specimen D 23.08.98.5 (Text-fig. 10a, b) shows the ridges parallel to the dorsal and posterior border of the maxillary plate, the ridges bend in a dorsal and ventral direction. The ridges parallel to the dorsal margin are anteriorly bent in a ventral direction. The vertical arrangement of closely positioned ridges near to the anterior margin of the maxillary plate as described by Poplin (1999: fig. 3B) does not appear regularly. They were recorded on specimen D 11.11.95.17 (Text-fig. 10e, f) only, and these differences probably occur within the range of sculpture variability on the maxilla. The tubercles and ridges bear microsculpture consisting of conspicuous ridges on the top (Poplin 1999: fig. 3E). The maxilla is characterized by large areas without sculpture. The sculpture on the anterior narrow suborbital part 


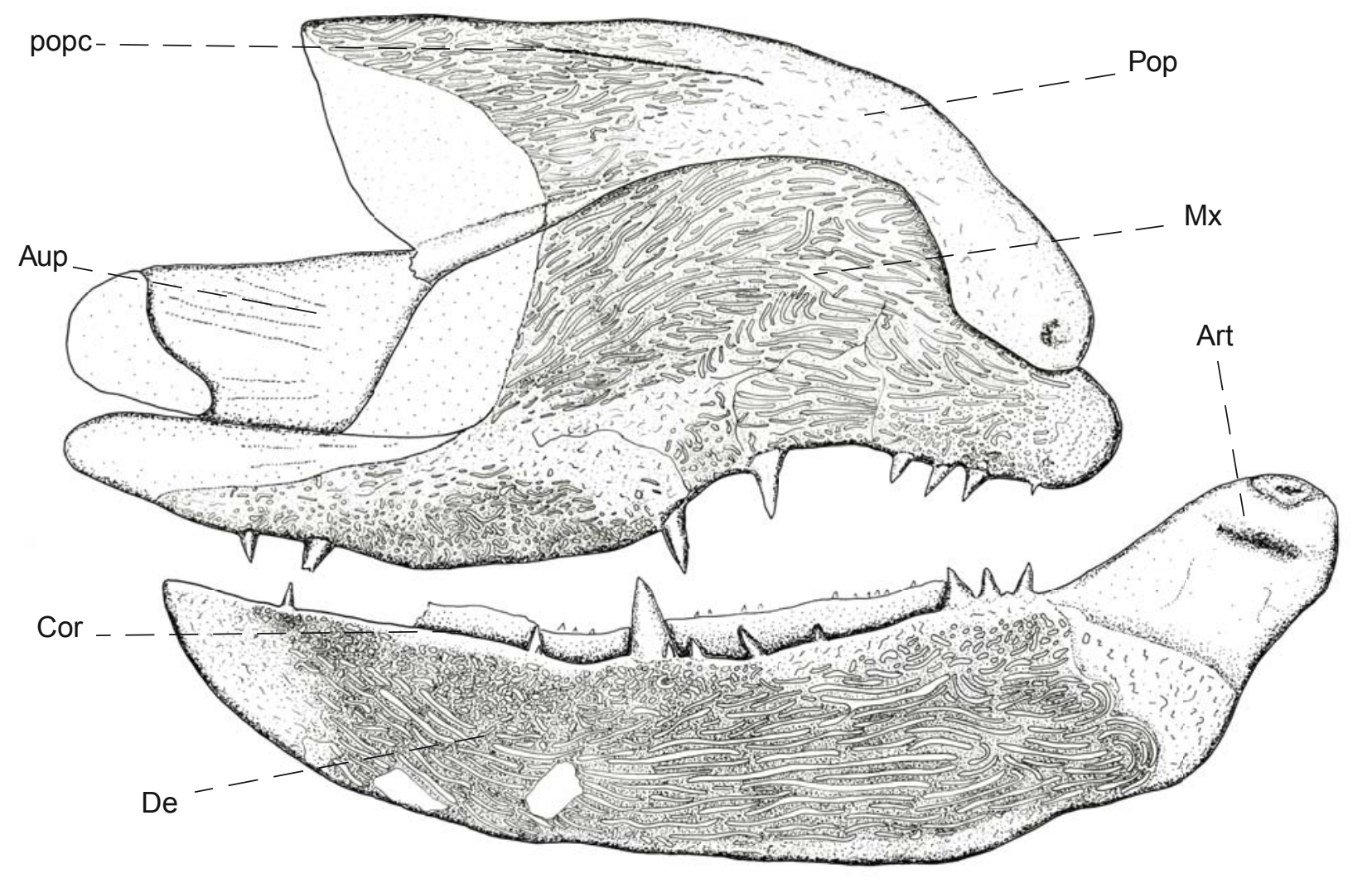

a

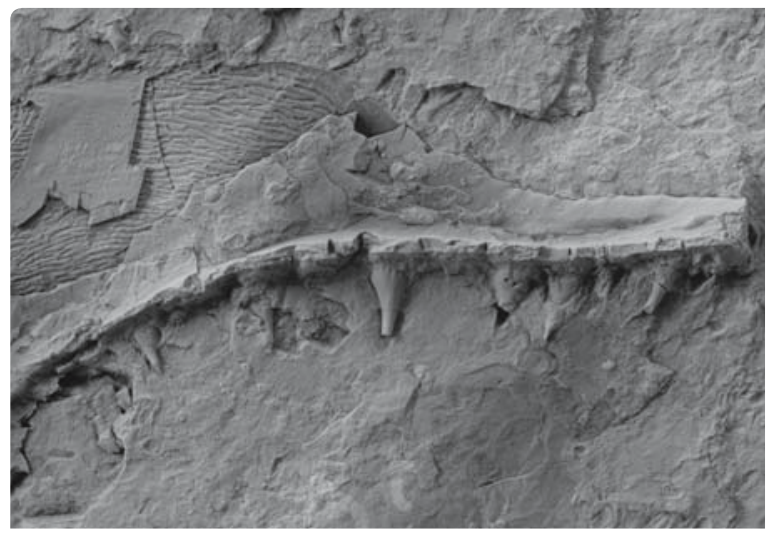

b

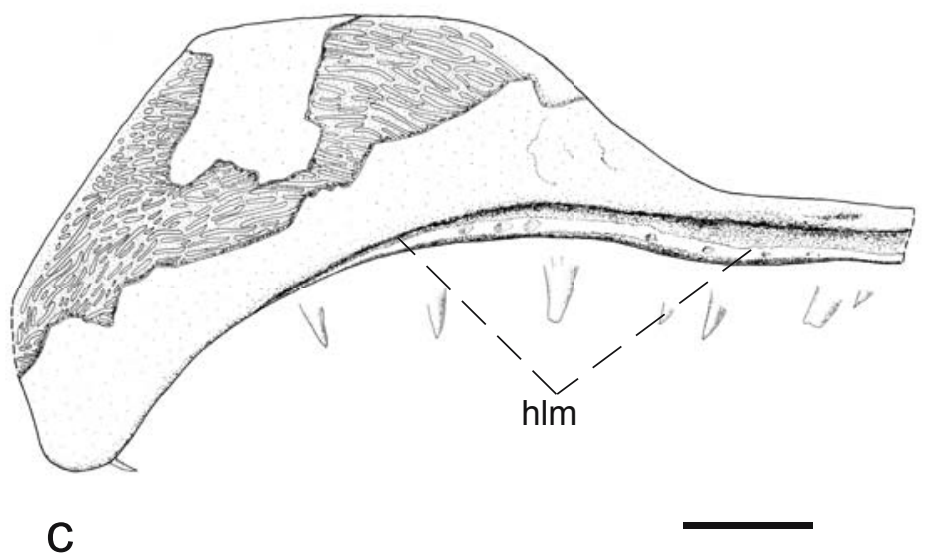

Text-fig. 11. Progyrolepis heyleri Poplin, 1999. a - set of bones of the left side of the cheek demonstrates the strong lower jaw, maxilla and preoperculum of old specimen. Large anterior regions of the preoperculum and maxilla are without sculpture, they were covered by the jugale. D 04.10.98.5. Scale bar $5 \mathrm{~mm}$. b, c - photograph and drawing of the left maxilla of juvenile specimen D 13.04.97.6 with conspicuous horizontal lamina, whitened. Scale bars 5 mm. Abbreviations: Art - articulare; Aup-autopalatinum; Cor - coronoid; De - dentalospleniale; hlm - horizontal lamina of preoperculum; Mx - maxilla; Pop - preoperculum; popc preopercular canal.

of the maxilla is limited to the narrow ventral part of its lateral surface, while the dorsal part of its lateral surface is without sculpture (Text-figs 10a-e, 11a). This unsculptured portion was covered by the lachrymal and partly by the jugal. More extensive is the unsculptured anterior part of the maxillary plate, where it has been preserved (Text-figs 10 a-e, 11a). This unsculptured part has a continuation on the unsculptured anterior region of the preoperculum (Text-fig. 11a), and was covered by the large jugal during the life of the animal.

Two groups of several holes representing nerve foramina for branches of the horizontal pit line of the maxillary nerve
(Text-fig. 10c) are situated in the transition area between the narrow suborbital part of the maxilla and the maxillary plate, this is also the radiation centre. The same foramina grouping was described by Nielsen (1942: pl. 9, fig. 1) in Pteronisculus and Gardiner (1984: fig. 66) in Moythomasia durgaringa, and they are common in many other Permian actinopterygians. The dentition of the maxilla is well developed along the whole ventral border of the bone including the ventroposterior process of the maxilla.

If we compare the shape of the maxilla with that in other actinopterygians it is clear that the postorbital maxillary 
plate is significantly longer than in Cheirolepis, Mimipiscis, Pteronisculus, Pygopterus nielseni or in Elonichthys krejcii. In Elonichthys germari the ratio of the postorbital plate compared to the length of the maxilla is similar to that in $P$. heyleri, but the maxillary plate is not so deep relative to the length (personal observation). The studied maxillary plate is, on the contrary, shorter than in Nematoptychius greenocki and Watsonichthys pectinatus (TRAQUAIR, 1877) (personal observation). Schindler (2018b) figured the maxillary plate of Rhabdolepis macropterus which is longer than in Progyrolepis heyleri, and the anterior margin of the maxillary plate is very low, and makes an angle of $24^{\circ}$ with the denticulated ventral margin of the maxilla. This angle in E. germari is about $45^{\circ}$ (Schindler 2018a), and in Elonichthys fritschi is $46^{\circ}$ (Schindler 2017). The shape of the maxilla in $P$. heyleri fully corresponds with that in Progyrolepis speciosus as figured by Fritsch (1883) and Stamberg (1991: fig. 15). A more recent revision of the upper jaws of Progyrolepis speciosus shows that the length of the maxilla represents 1.8 times the length of the maxillary plate, and the ratio of the length of the maxillary plate to the length of the narrow suborbital section is 1.1 and not 0.9 as quoted by Štamberg (1991).

Dentition. Well preserved marginal teeth in the sense of Poplin and Heyler (1993) are present on the maxilla and dentalosplenial. The same type of predatory dentition is on both the lower and upper jaws. The teeth on the jaws are arranged in two rows (Text-figs 10a-d, 11, 13, 14), the outer row consists of small sharply pointed teeth of variable size. The inner row is formed by 12 to 14 large conical teeth (BX 17.10.98.2) characterizing a predatory fish. The teeth on the lateral row are not all the same size, but are always 4-7 times shorter than the laniaries conical teeth on the medial row. Dentition in a young specimen can be a little different. The dentition of adult specimens also consists of two types of teeth in two rows on the maxilla. 12-14 large conical teeth form the medial row, and numerous much smaller teeth form the lateral row. The $27 \mathrm{~mm}$ long lower jaw of young specimen, D 09.11.96.11, bears 16 large slenderconical sharply pointed teeth of which 13 are located on the anterior $1 / 3$ of the bone. Similarly in another specimen (D 07.11.98.4) in which the maxilla is $48 \mathrm{~mm}$ long, there are 15 large slender conical teeth located along the ventral margin of the maxilla. The conical teeth on the older specimens are of course larger, and they have a wider base compared to their length. Calculating the ratio of tooth height (th) to head depth (dh) in front of the opercular series in the sense of Poplin and Heyler (1993) is of only limited use in the specimen D 11.11.95.7 where the ratio of $\mathrm{dh} /$ th is 22. The acrodin apex of $P$. heyleri teeth is smooth (Text-fig. $15 \mathrm{c})$, but the remaining part of the tooth corpus is sculptured with longitudinal ridges distributed around the periphery of the tooth. In addition, a different fine microsculpture is observable on the whole surface of the tooth, with the exception of the acrodin apex. The fine microsculpture is formed by fine protuberances distributed on the surface of the tooth (Text-fig. 15d-g). The elliptical protuberances are proximo-distally elongated, spaced out from each other and only occasionally touch. The same microsculpture can also be observed on the small teeth of the outer row, with less space between the protuberances. Studies of the microsculpture on the large teeth on the internal row and much smaller teeth on the outer row, demonstrate a match with the microsculpture of $P$. speciosus. This microsculpture is not exclusive to the teeth of Progyrolepis speciosus as described by Poplin (1999), but is also common in P. heyleri and for this, in many extinct lower actinopterygian taxa (Richter 1983, Schindler 2018a). Dentition on the upper and lower jaws of Progyrolepis heyleri is partly similar to the dentition on the lower jaw of Usclasichthys macrodens Heyler, 1977 from the Lodève Basin as figured by Heyler (1977). Comparing the large conical teeth of P. heyleri and Usclasichthys macrodens, the main differences are in the size of the teeth and mainly in the swollen bases which contain a spacious pulp cavity in Usclasichthys macrodens. Different tooth morphology in P. heyleri and Usclasichthys macrodens was previously mentioned by Poplin (1999) and Steyer et al. (2000). Among the P. heyleri lower jaws are specimens which are very similar in characters to those of Usclasichthys macrodens. One of them is lower jaw D 14.03.98.19 (Text-fig 15b) which is 8-9 cm long, and presents large conical teeth $10 \mathrm{~mm}$ in height and with a 5 $\mathrm{mm}$ wide base in which the conical laniaries are of the same height as the depth of the lower jaw at the point where the teeth are inserted. It will be important if some future finds of Usclasichthys macrodens jaws retain the characters reported in the holotype described by Heyler (1977) or if the swollen bases of the teeth with large pulp cavities were only an artefact of preservation associated with compression during the process of fossilisation.

In addition to the marginal teeth small short sharply pointed teeth were developed covering the dorsal surface of the coronoids, particularly on the lower jaw, the medioventral surface of the ectopterygoid and dermatopterygoid on the upper jaw, and the ventral surface of the parasphenoid.

The preoperculum is a long bone angled along the dorsal border of the maxilla. It is possible to distinguish two distinct regions on the preoperculum, a wider anterior region and narrow posteroventral region of the bone (Text-fig. 11a). The whole bone lies in an oblique position in the skull, and its posterodorsal margin forms an angle of $15^{\circ}$ with the body axis. The anterior branch of the preoperculum is deep in the anterior area, but much less than is usual in many other palaeozoic actinopterygians. The ratio of the length of the anterior branch of the preoperculum to the depth of its anterior part is 2.5. The angle between the dorso-posterior margin of the anterior branch of the preoperculum and the posterior margin of the ventral branch of the preoperculum is around $130^{\circ}$. The anterior margin of the anterior branch is oblique thus the anterodorsal corner is more significantly pronounced anteriorly than the ventroanterior corner (Textfigs 11a, 20). The preoperculum borders posteriorly and dorsally the maxillary plate and the maxilla overlaps the ventral and anteroventral margin of the preoperculum. The ventral branch of the preoperculum is wedged between the maxillary plate, the operculum and the suboperculum. A large unsculptured anterior area of the preoperculum is covered by the large jugal (Text-fig. 20). Conspicuous sculpture consists mainly of long ridges arranged anteroposteriorly on the anterior branch of the preoperculum, while short ridges and tubercles prevail in the ventral narrow branch. The anterior part of the preoperculum presents a sharp 
borderline between the sculptured and unsculptured areas (Text-fig. 11a). The unsculptured part of the preoperculum leads up to the unsculptured anterior part of the maxillary plate, and both bare surfaces were covered by the large jugal. The preopercular canal traverses along the dorsoposterior margin of the preoperculum from where the preoperculum bends in an anterior direction and it leaves the preoperculum on its dorsal side just before the dorsoanterior angle of the preoperculum. Traversing of the preopercular canal is partly similar to that in Mimipiscis toombsi where the preopercular canal leaves the dorsal margin earlier (Gardiner 1984). The preopercular canal traversing along the posterior margin of the ventral branch of the preoperculum and then along the posterodorsal margin of the anterior branch of the preoperculum is well preserved in medial view in specimens D 14.03.97.12 and D14.03.97.10. Conspicuous thickening of the bone is visible where the preopercular canal passes and particularly where the bone bends. This region is also the centre of ossification of the preoperculum. Thickening of the bone in the area through which the preopercular canal passes represents the horizontal lamina (Text-fig. 7) which probably reinforces cohesion of the preoperculum and palatoquadrate. The fixed connection between the preoperculum and palatoquadrate was previously figured by Nielsen (1942: fig. 35) in Pteronisculus magnus. The bend, obliqueness and the shape of the preoperculum are the conspicuous anatomical features characterizing different actinopterygian species. In Mimipiscis toombsi the dorsoanterior branch of the preoperculum is significantly shorter, connected with the significantly shorter maxillary plate (Gardiner 1984). In Howqualepis rostridens LoNG, 1988 the preoperculum is only slightly bent with the dorsoanterior branch deeper anteriorly (Long 1988: fig. 14) but not as much as in $P$. heyleri. The preoperculum of Pteronisculus on the contrary is more similar to that of $P$. heyleri, and it resembles that species both in the angle of the bend and the ratio of the antero-dorsal and ventral branches of the bone.

The jugal (D 09.11.96.3; D 10.08.95) is the largest and best preserved of the bones making up the infraorbital series. The bone forms two thirds of the posterior margin of the orbit, it is slightly concave anteriorly and strongly convex posteriorly (Text-figs 12, 20). The jugal significantly overlaps the smooth anterior area of the maxillary plate and partly also the smooth anterior area of the preoperculum. The infraorbital canal passes arcuately across the anterior half of the bone, and small channels split off from the infaorbital canal in a fan-like manner (Text-fig. 12a). The shape of the jugal is a distinguishing feature among the actinopterygians. An identical shape was described by Schindler (2018a) in Elonichthys germari, and Štamberg (2010a) in "Elonichthys" krejcii, and a similar shape was also described by Gardiner (1984: fig. 73) in Moythomasia durgaringa and Long (1988) in Mansfieldiscus sweeti (WoODWARD, 1906). As regards the lachrymal, it is not preserved, but its presence is obvious when considering the smooth dorsal region of the suborbital part of the maxilla, the lachrymal formed the ventral border of the orbit and greatly overlapped the suborbital part of the maxilla (Text-fig. 20).

Lower jaw. The lower jaw is preserved in many specimens such as D 02.03.969.9; D 04.10.98.5; D 09.11.96.9; BX 04.10.98.2; BX 08.12.97.5; BX 10.05.96.5; BX 14.01.96.1; BXM 094 etc. It is a very robust bone with the anterior portion curving in medially. The largest whole lower jaw is $10 \mathrm{~cm}$ long (BX 14.01.96.1), but fragments of longer jaws are known. The lower jaw is a complex of several bones. The basic axis of the lower jaw is formed of Meckel's cartilage which is totally ossified only in the posterior part of the jaw where it protrudes dorsally as pars

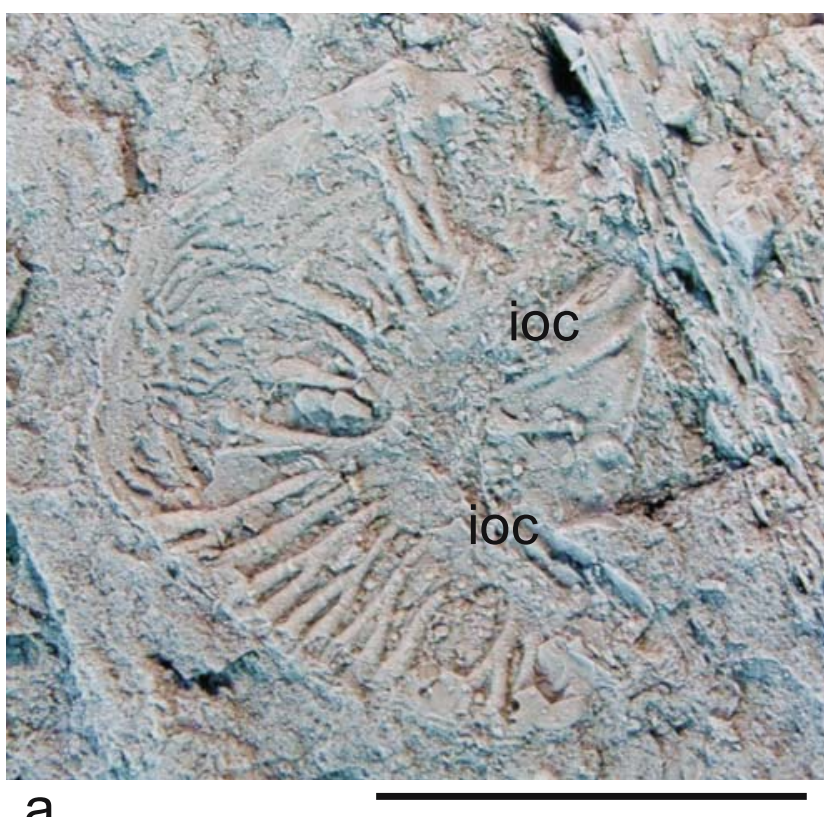

a

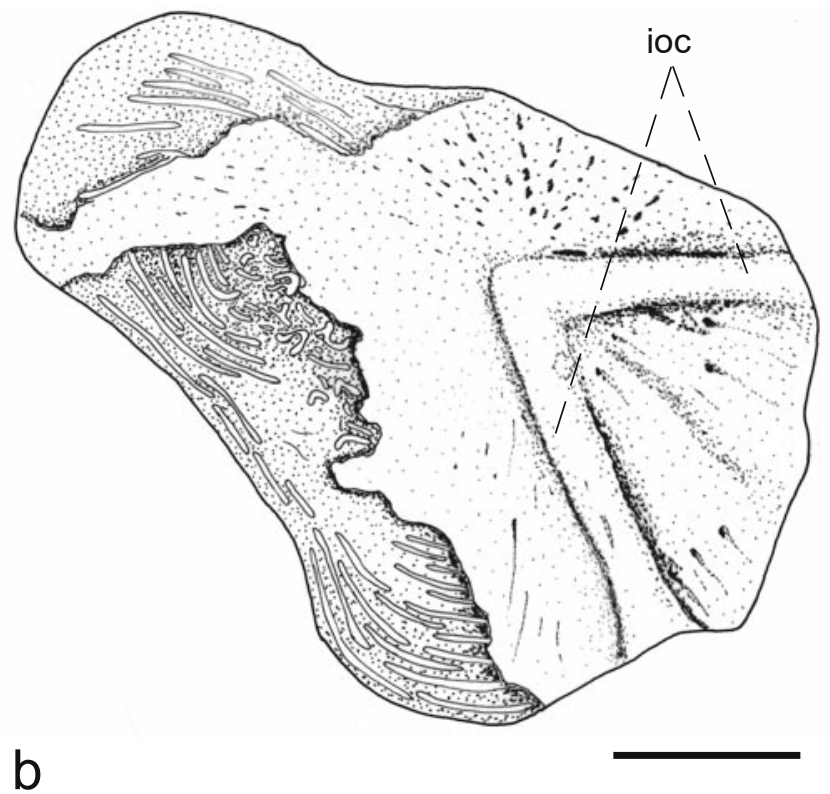

Text-fig. 12. Progyrolepis heyleri PopLIn, 1999. a - isolated jugal in medial view with conspicuous ridges fanny diverging from the radiation centre situated in the centre of the arched bend in the infraorbital canal. Specimen D 09.11.96.3, whitened. Scale bar $5 \mathrm{~mm}$. Abbreviation: ioc - infraorbital canal. b - isolated jugal in medial view with infraorbital canal. The rests of the sculpture on lateral face of the bone are observable in places of lacking bone. Specimen BX 10.08.95. Scale bar 5 mm. Abbreviation: ioc infraorbital canal. 

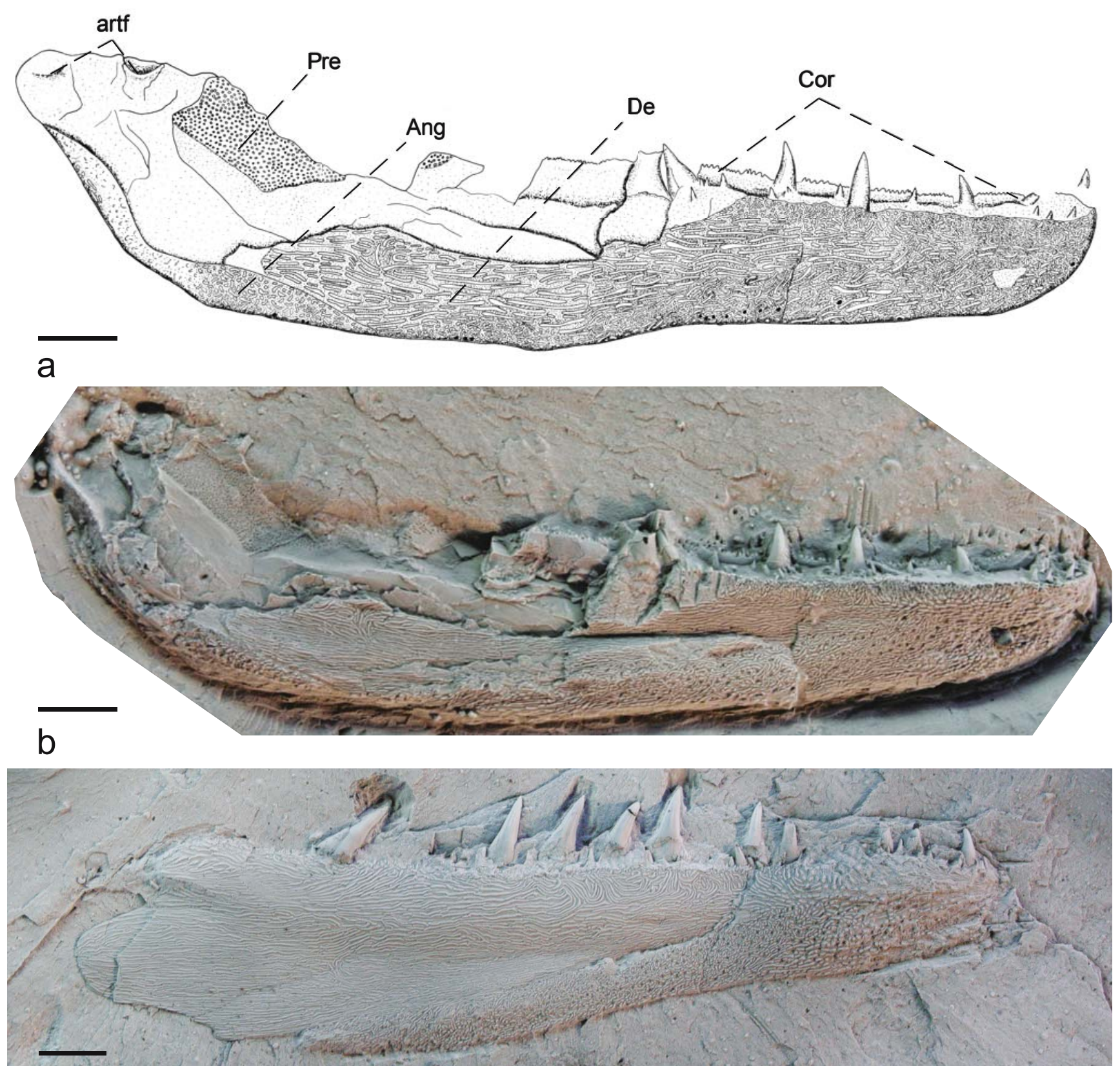

C

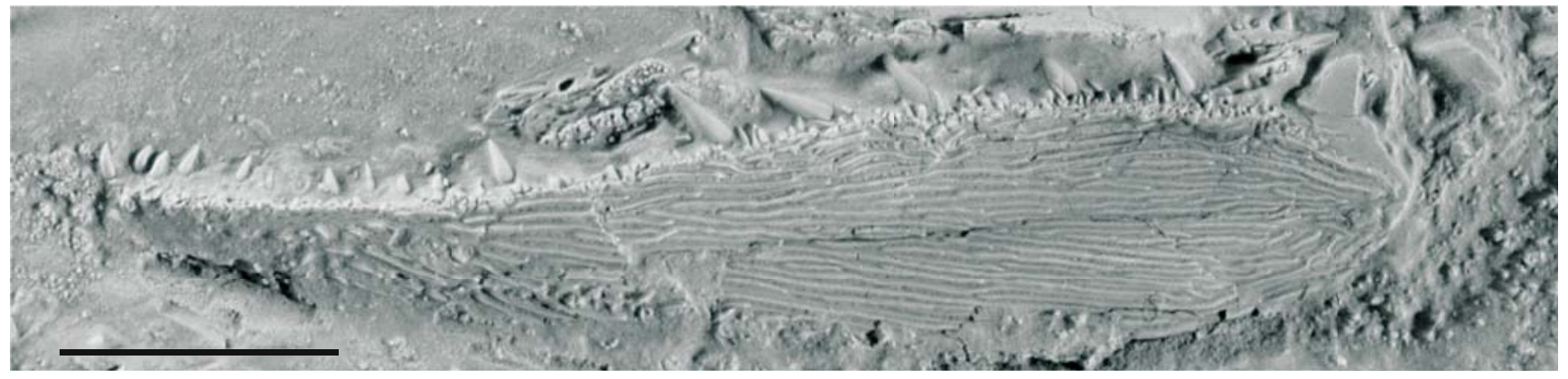

d

Text-fig. 13. Progyrolepis speciosus Poplin, 1999. a - drawing and b-photograph of the right lower jaw in lateral view. D 02.03.96.9, whitened. Scale bars $5 \mathrm{~mm}$. c - right dentalosplenial in lateral view. D 17.09.96.4, whitened. Scale bar $5 \mathrm{~mm}$. $\mathrm{d}$ - left lower jaw of a juvenile specimen. D 09.11.96.11, whitened. Scale bar 5 mm. Abbreviations: Ang - angular; artf - articular facet; Cor - coronoid; De - dentalosplenial; Pre - prearticular.

articularis with distinct medial and lateral facets (Textfigs 13a, b, 14a-c). These facets articulate with the double condyle of the quadratum. The large adductor fossa for the adductor mandibularis anteriorly reaches to the facets of the pars articularis (Text-fig. 14a-c). Anterior ossification of the Meckelian cartilage which was observed in 


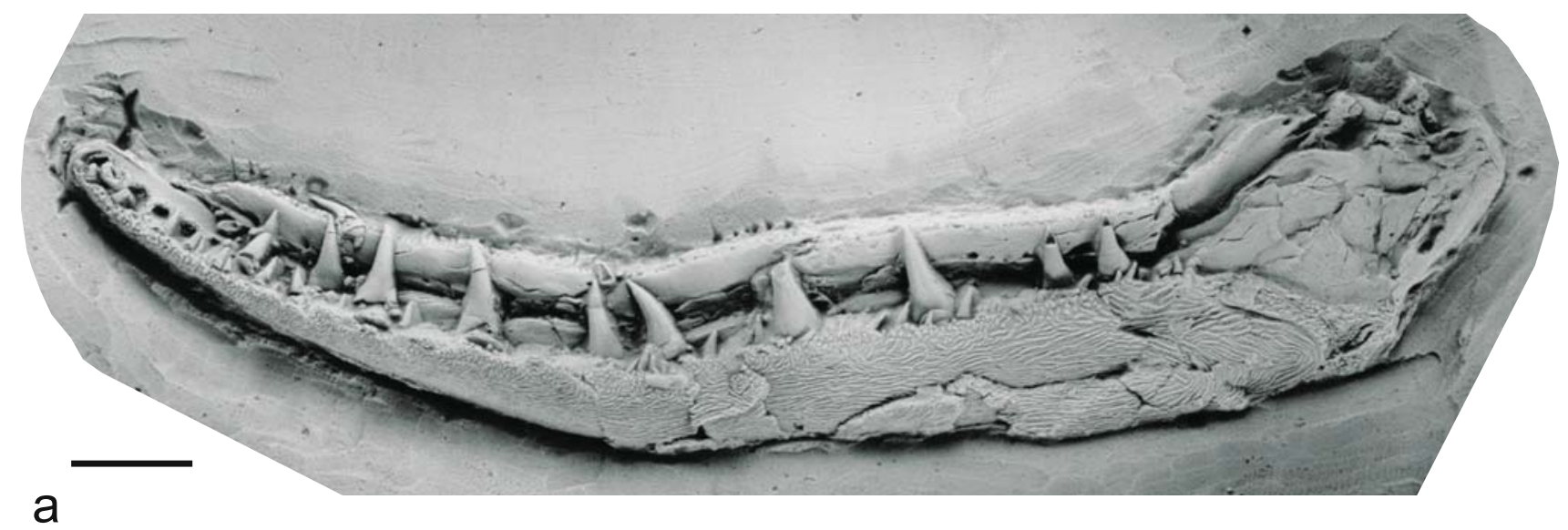

a
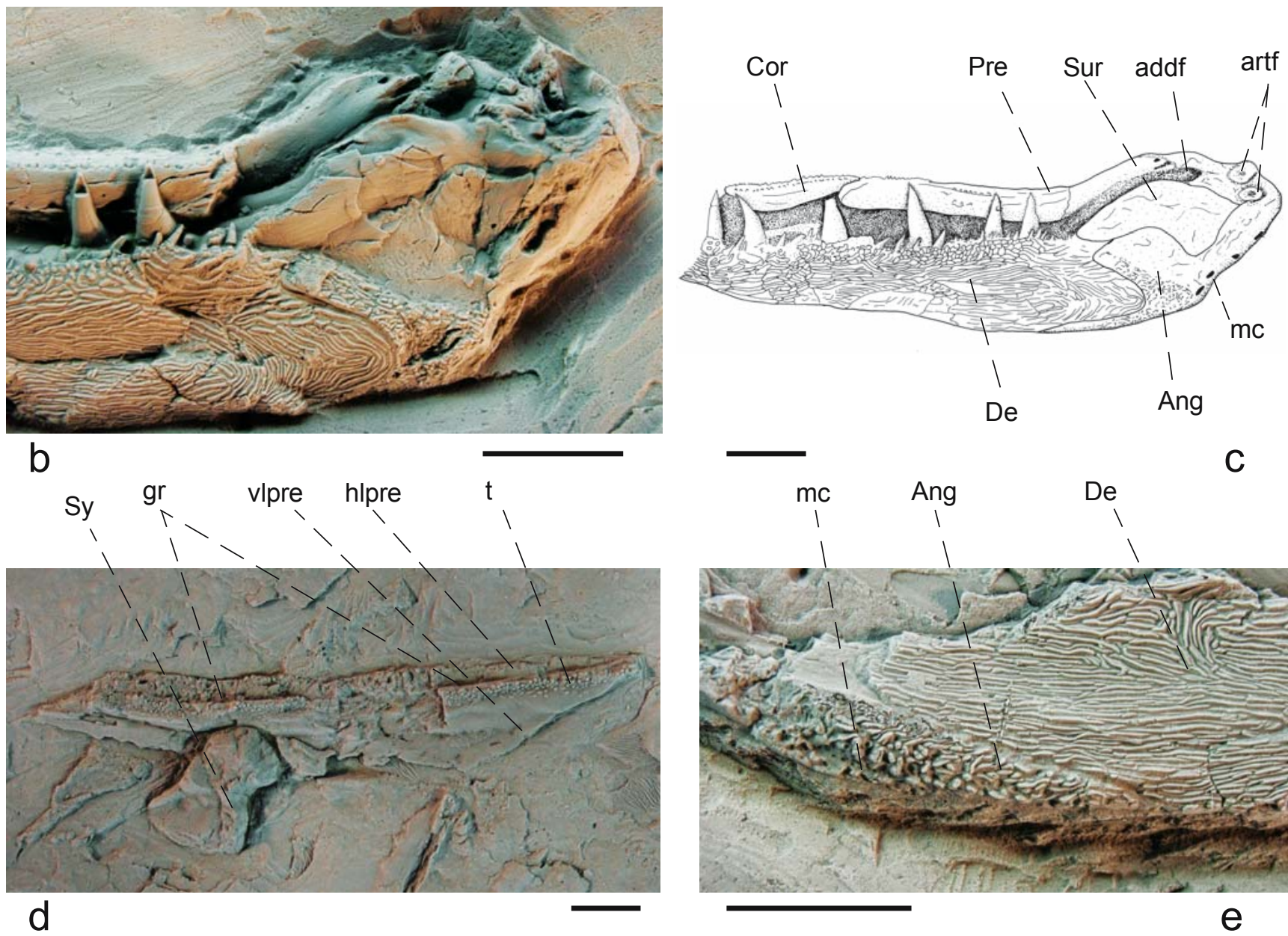

Text-fig. 14. Progyrolepis heyleri Poplin, 1999. a - left lower jaw in dorsolateral view. BXM 094, whitened. Scale bar 5 mm. b - photograph, whitened and c - drawing of the posterior part of the left lower jaw. BXM 094. Scale bars $5 \mathrm{~mm}$. $\mathrm{d}$ - right prearticular in medialview. D 14.03.98.19, whitened. Scale bar $5 \mathrm{~mm}$. e - angular and posterior part of the dentalosplenial in lateral view. Borderline between the dentalosplenial and the angular is clearly noticeable on the basis of distinct sculpture. D 02.03.96.9, whitened. Scale bar $5 \mathrm{~mm}$. Abbreviations: Ang - angular; addf - adductor fossa; artf - articular facet; Cor - coronoid; De dentalosplenial; gr - groove on prearticular; hlpre - horizontal lamina of prearticular; mc - mandibular canal; Pre - prearticular; Sy - symplectic; sur - surangular; $t$ - teeth; vlpre - vertical lamina of prearticular.

Mimipiscis toombsi, Moythomasia durgaringa by Gardiner (1984), in Nematoptychius greenocki by Watson (1928) or Pteronisculus magnus by Nielsen (1942) is missing in $P$. heyleri. A significant groove is present where the Meckelian cartilage would have been. On the contrary in medial view the dentary is conspicuously thickened along its dorsal and ventral margins (Text-fig. 15b) as similarly figured by Long (1988) in Howqualepis rostridens. The lateral surface of the lower jaw is composed of three dermal bones, the dentary, the angular and the supraangular, which forms the lateral wall of the adductor fossa. The dentary is the largest bone, elongated in an anteroposterior direction, slightly deeper posteriorly, and anteriorly it is curved medially. The dentary bears conspicuous sculpture consisting of predominantly long ridges which elongate in an anteroposterior direction. Short ridges in combination with tubercles are developed along the 
dorsal margin of the dentary and in the anterior part of the dentary. Identical sculpture was figured by Štamberg (1991) in Progyrolepis speciosus, and also is present on the type specimen of Elonichthys germari (personal observation). The sculptured part of the dentary is rounded posteriorly, and it overlaps the anterior margin of the angular (Text-fig. $14 \mathrm{a}-\mathrm{c}, \mathrm{e})$. In some specimens the dentary exhibits slight differences in the sculpture. Specimen D 02.03.96.9 shows ridges bending upward from an anteroposterior direction in the posterior third of the dentary (Text-fig. 14e). The sculpture on the dentary of young specimens consists exclusively of long ridges regularly arranged in an anteroposterior direction (Text-fig. 13d).The mandibular sensory canal traversed from the anterior end along the ventral margin of the bone in a posterior direction and posteriorly it traversed to the angular. The pores of the mandibular canal are arranged in a line. In addition, there are some small pores spread over the surface of the anterior half of the dentary (Text-fig. 13b, c). These pores probably mediated environmental perception.

The angular continues posteriorly to the dentary (Textfigs $13 \mathrm{a}, \mathrm{b}, 14 \mathrm{a}-\mathrm{c}, \mathrm{e})$. The angular is much smaller than the dentary and is approximately triangular in shape with the triangle base located on the posteroventral margin of the lower jaw (Text-fig. 14c). The angular forms one third of the total length of the lower jaw in a posteroanterior direction similarly as in Mimipiscis toombsi or Moythomasia durgaringa (Gardiner 1984, Choo 2011) but contrary to Pteronisculus magnus (Nielsen 1942) or Nematoptychius greenocki (Watson 1928) where it forms one half of the lower jaw total length. Also in Elonichthys germari the angular is extended more anteriad (Schindler 2018a). The borderline between the dentary and the angular is clearly visible due to its distinct sculpture. The posterior region of the dentary bears long ridges arranged anteroposteriorly while the angular exhibits short ridges and tubercles (Textfigs $13 a, b, 14 a-c, e)$. The mandibular sensory canal is traceable via the holes which traverse from the dentary to the angular, close to the ventral margin of the bones and it continues along the posterior margin of the angular (Text-figs $14 \mathrm{a}-\mathrm{c}, \mathrm{e}, 20$ ). The angular is dorsally sutured to the supraangular in an interdigitating suture and both the angular and the supraangular are devoid of sculpture in the area where the ventroposterior part of the maxilla overlaps these bones (Text-figs 13a, b, 14a-c). The supraangular occurs in some palaeoniscoids such as Moythomasia durgaringa, Nematoptychius greenocki, Pygopterus nielseni, Pteronisculus magnus etc. but in others it is absent, e. g. Mimipiscis toombsi (Gardiner 1984).

The lower jaw in medial view exhibits a complex of bones. The largest of them is the prearticular, medially surrounding the space for the adductor mandibularis. The prearticular (Text-figs 13a, 14d) is bent dorsoventrally and forms the horizontal lamina, in front of the adductor fossa, the lamina extends to half the length of the lower jaw. The horizontal lamina laterally borders with the dentary, and it is covered by shagreen of small teeth. The teeth on the horizontal lamina of the prearticular near to the border with the dentary may be sharp and pointed similar to the small teeth on the dentary. Medially the teeth are minute or form a shagreen of small tubercles which gradually pass towards the ventral region of the prearticular which is completely smooth along its ventral margin (Text-fig. 14d). The ventral part of the prearticular covers the Meckelian cartilage medially. Anterior to the prearticular are four coronoids (Text-figs 13a, b, 14a-c). They are much smaller than the prearticular, and they overlap one another in an anteroposterior direction. The coronoids bear shagreen of small teeth similarly as in the prearticular. Progyrolepis heyleri has four short coronoids as in Mimipiscis toombsi or Moythomasia durgaringa (Gardiner 1984: figs 92, 95), but the $P$. heyleri coronoids are accompanied by a long prearticular reaching half way along the length of the lower jaw. The prearticular in Pteronisculus magnus is also conspicuously elongated anteroposteriorly but only three coronoids are present (Nielsen 1942: fig. 40).

Hyoid arch. The bones of the hyoid arch are preserved as a complex of isolated bones which compose the arch. The hyomandibula, the symplectic and the ceratohyal for certain can be recognised in the material. The hyoid arch bones are preserved in many specimens such as D 06.09.98.3; D 09.11.96.5; D 14.03.97.10; BX 12.05.98.5; BX 10.08.95 etc.

The hyomandibula is a large, stout conspicuously dorsoventrally elongated bone, angularly bent, and with a significant anterior inclination (Text-figs 7, 16a-d). It consists of two clearly distinct arms forming an angle of 151-157 . The dorsoanterior arm is widest anteriorly where it is visibly compressed from the lateral and medial sides. It narrows backwards towards the point where the two arms join. The ventral arm is $10 \%$ shorter than the dorsoanterior one, it is narrower and not lateromedially compressed. The ventral end of the ventral arm is straight, and it articulates with the symplectic. The processus opercularis is well developed in lateral view on the posterior margin of the bone in the area where it bends. The processus opercularis is formed by the hump of the round ground and points lateroposteriorly (Text-fig. 16a-c). A thin posterior lamina stretches along the posterior margin of the dorsal arm of the hyomanibular in a dorsal direction from the processus opercularis (Textfig. 16a, b). A conspicuous narrow groove originates at the level of the processus opercularis and traverses between the dorsal arm of the hyomandibula and the posterior lamina (Text-fig. 16a, b). This groove can be compared with the truncus hyoideomandibularis facialis canal figured by Nielsen (1942) in Pteronisculus magnus, by Aldinger (1937) in Pygopterus nielseni and by Štamberg (2010a) in Rhabdolepis saarbrueckensis. The processus opercularis is well preserved, and located ventral to the posterior lamina. This is different from Pygopterus nielseni where the processus opercularis is figured as running dorsally to the posterior lamina (Aldinger 1937: fig. 41A). The processus opercularis is also well developed in Rhabdolepis saarbrueckensis and on the type material of Elonichthys crassidens as figured by Štamberg (2010a: fig. 4) and Schindler (2018a: fig. 40). On some specimens, a hole is visible ventral to the processus opercularis (Text-fig. 16a, b). This hole may indicate the presence of a hyomandibular canal as was described by Gardiner (1984) in Mimipiscis toombsi and Moythomasia durgaringa. The presence of such a canal is not $100 \%$ clear, and a continuation of the canal on the medial side of the hyomandibular was not apparent. The shape of the hyomandibula, including the bend in the bone and the shape of the processus opercularis correspond to that figured by Schindler (1993) in Meisenheimichthys palatinus and by Štamberg (2010a) in Rhabdolepis saarbrueckensis. The 

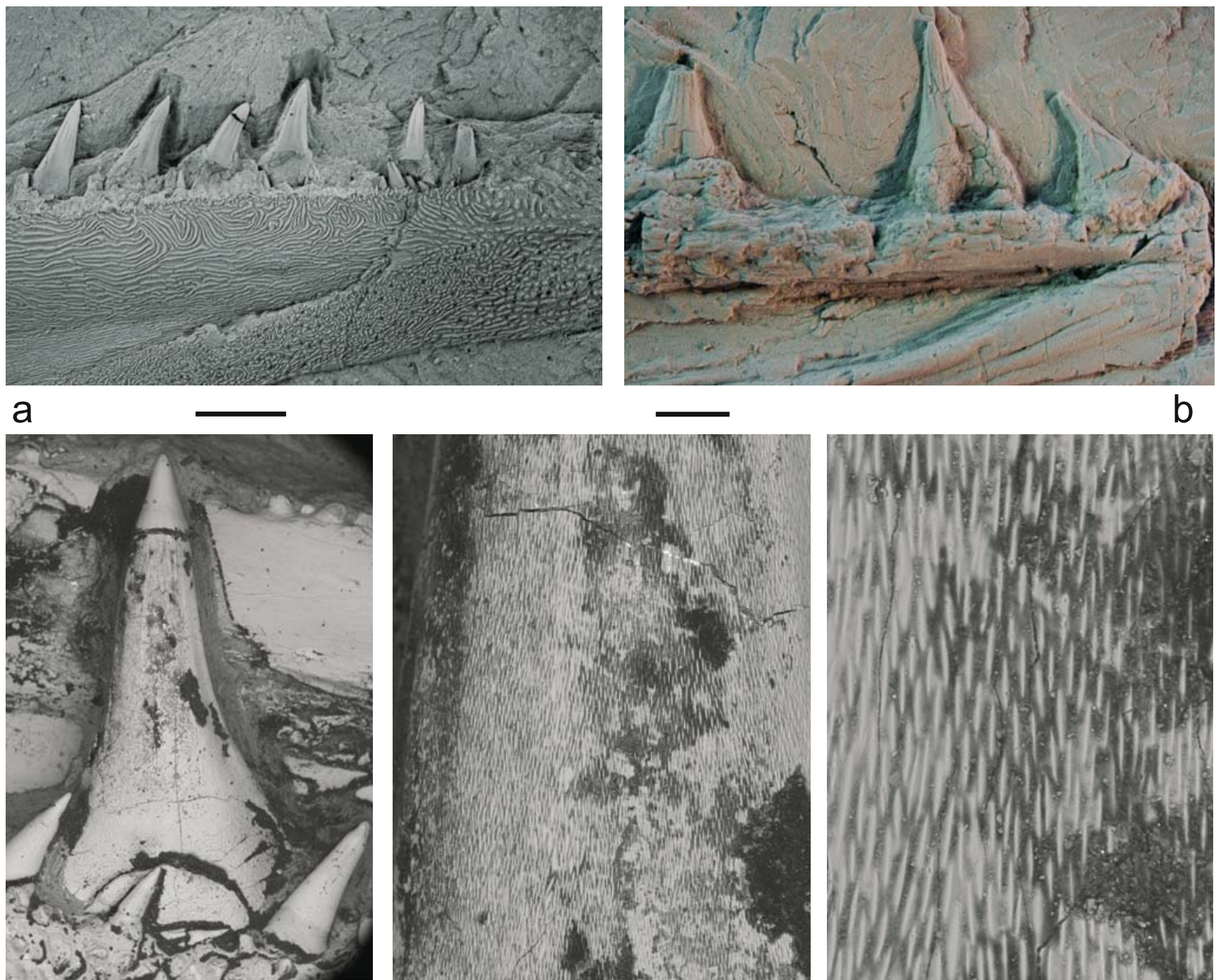

C
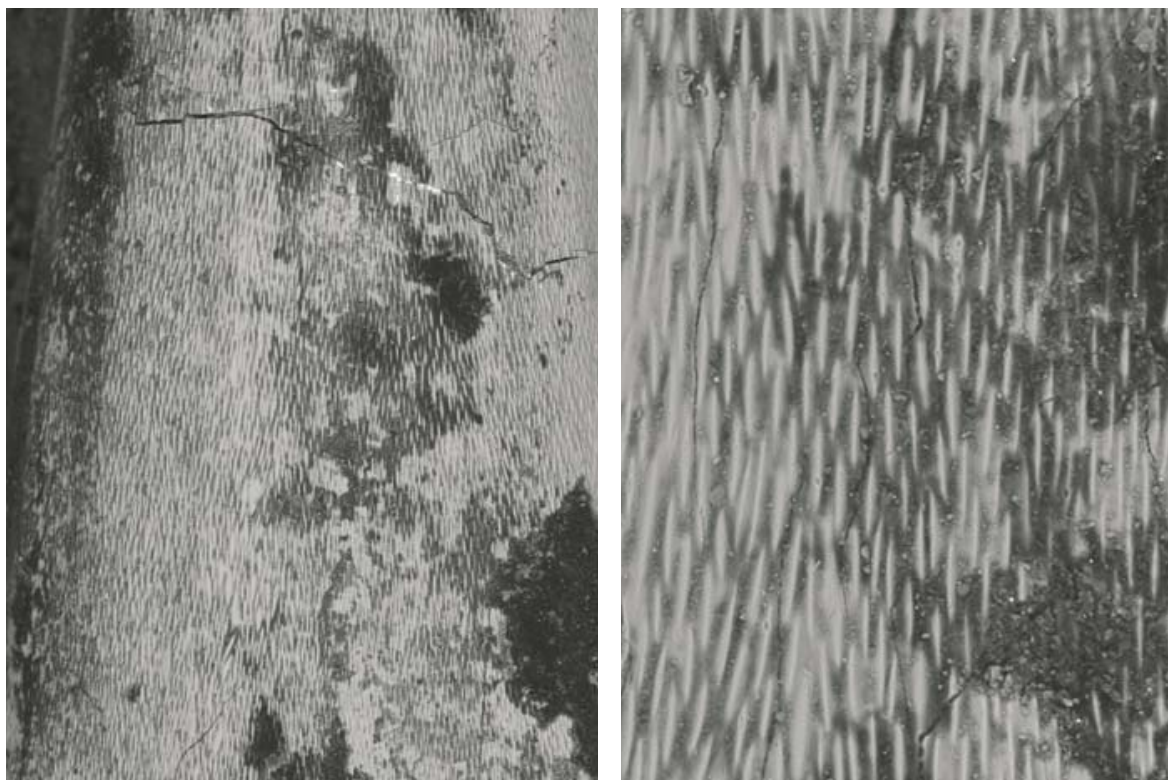

d

e
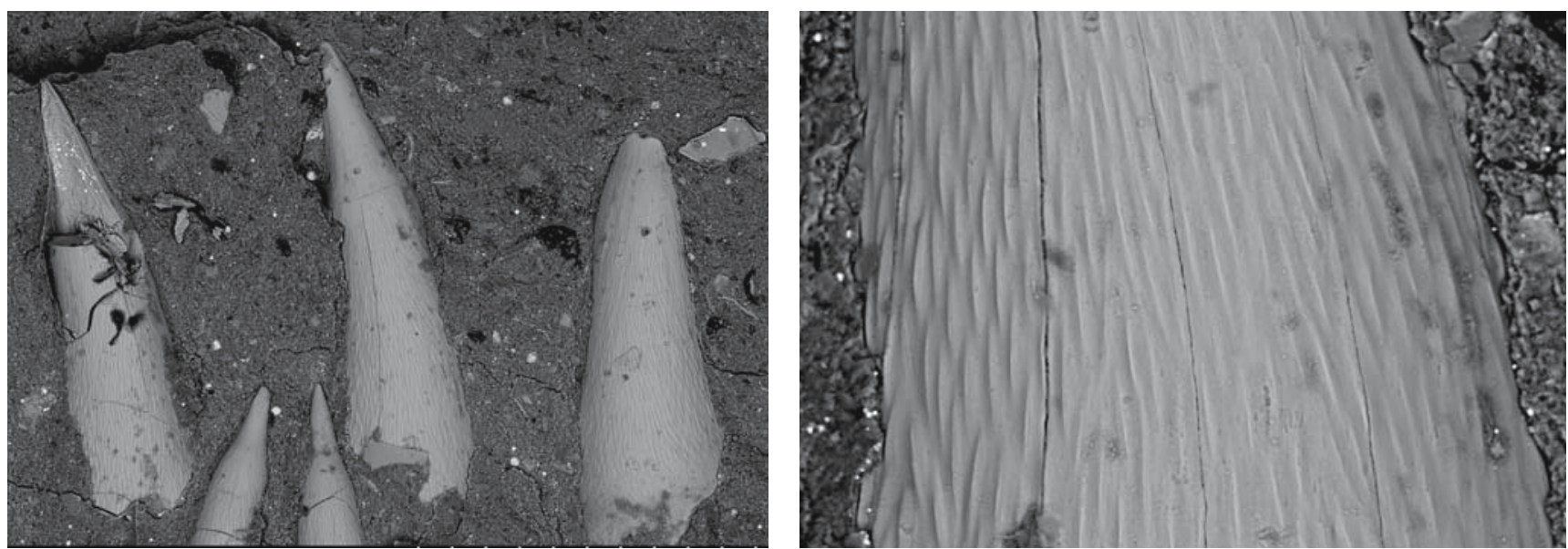

f

Text-fig. 15. Progyrolepis heyleri Poplin, 1999. a - row oflarge conical teeth on the right lower jaw. D 17.09.96.4, whitened. Scale bar $5 \mathrm{~mm}$. b - large conical teeth with wide base and spacious pulpal cavity, and conspicuous grooves on the narrow part of the teeth in the anterior part of the lower jaw. The dentary is in medial view, conspicuously thickened along its dorsal and ventral margins. D 14.03.98.19, whitened. Scale bar $5 \mathrm{~mm}$. $\mathrm{c}$ - large conical tooth from the internal row and three much smaller teeth from the outer row of the lower jaw. Scale bar $1 \mathrm{~mm}$. d, e - microsculpture formed by elliptical proximo-distally elongated protuberances on the large tooth. Scale bars $100 \mu \mathrm{m}$. $\mathrm{f}$ - three large slender teeth of the internal row and two teeth of the outer row of the lower jaw of a subadult specimen. D 13.04.97. Scale bar $400 \mu \mathrm{m} . \mathrm{g}$ - microsculpture formed by elliptical proximo-distally elongated protuberances on the large tooth. D 13.04.97. Scale bar $50 \mu \mathrm{m}$. 


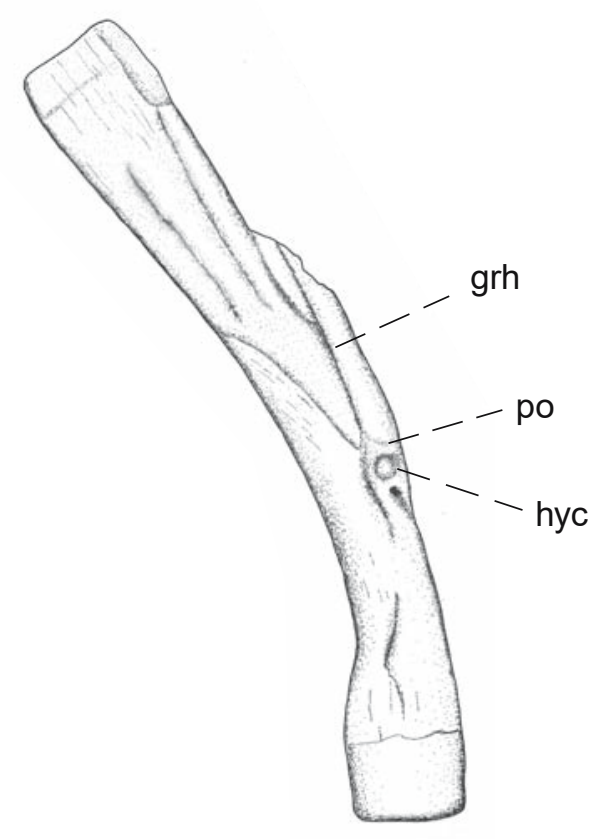

a

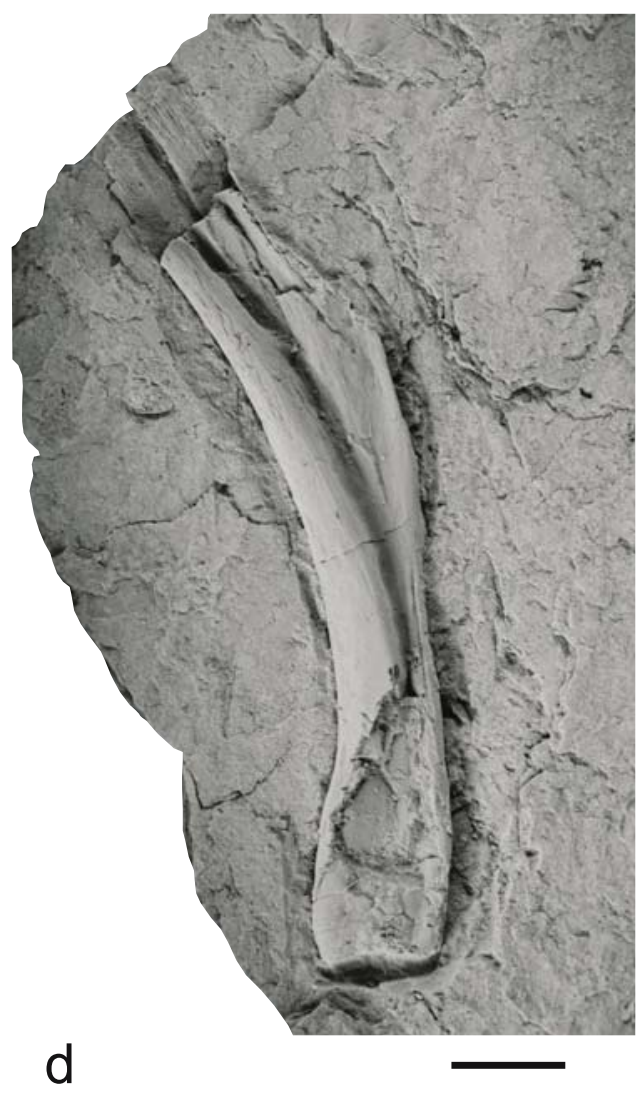

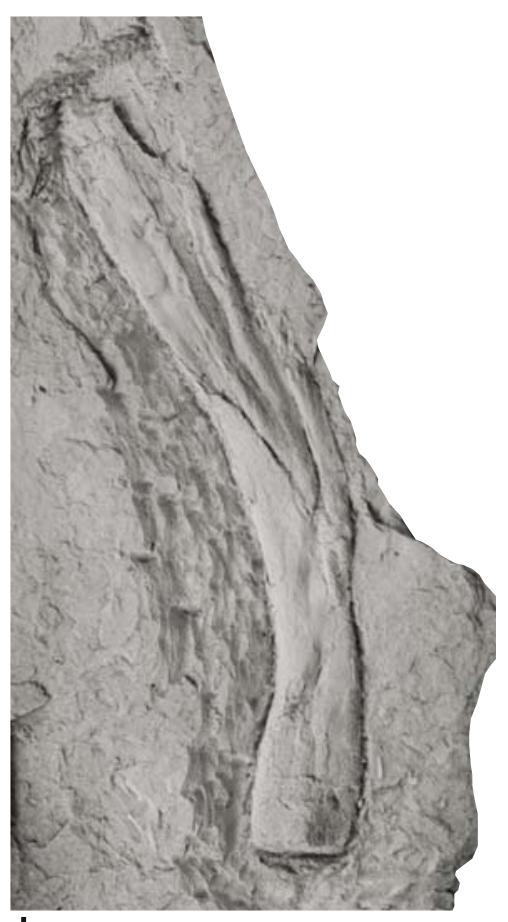

b
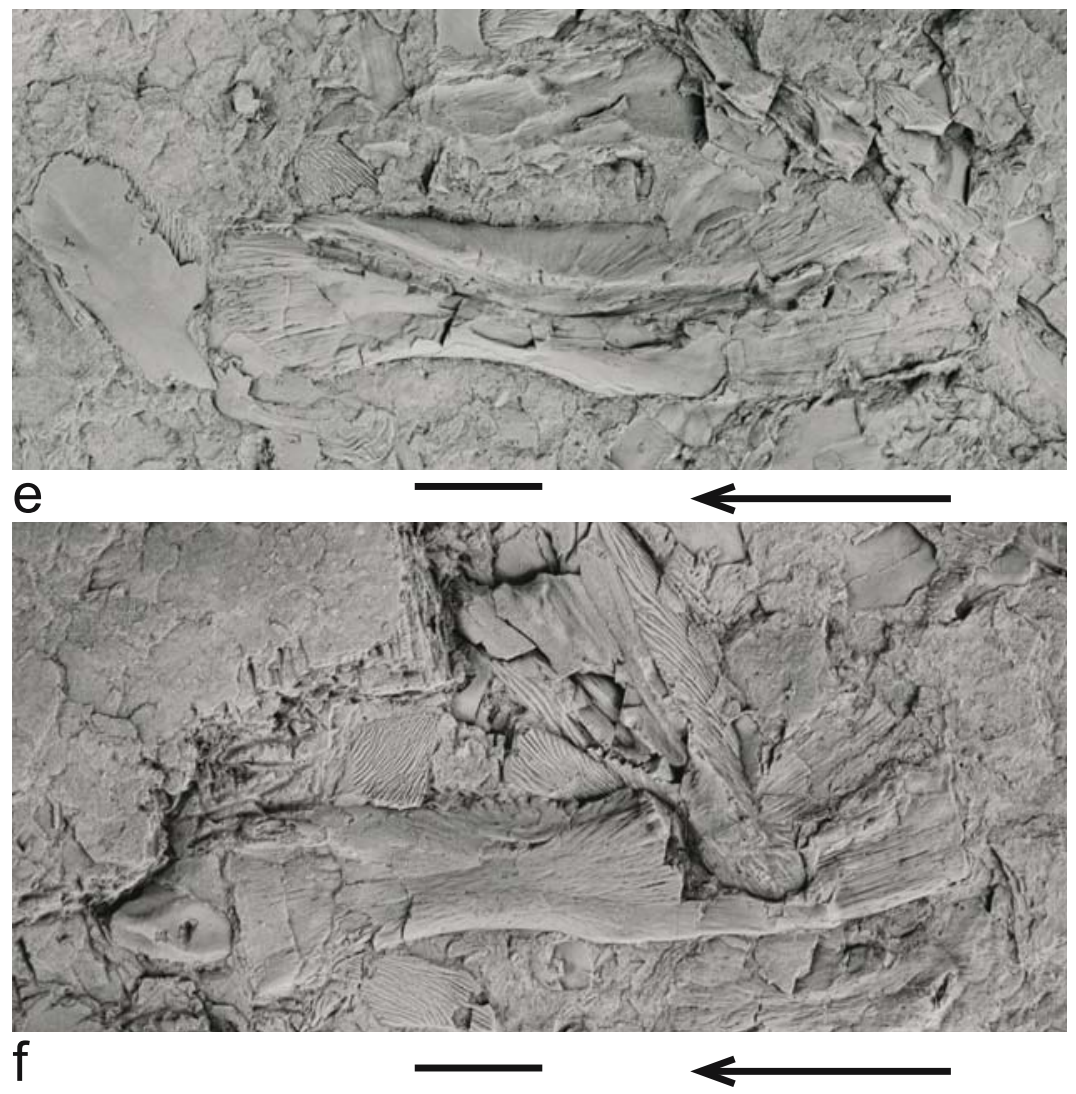

Text-fig. 16. Progyrolepis heyleri Poplin, 1999. a, b - drawing and photograph of the left hyomandibula in lateral view. D 02.03.96.9, whitened. Scale bars $5 \mathrm{~mm}$. c - drawing of the left hyomandibula in lateral view. D 09.11.96.5. Scale bar 5 mm. d - right hyomandibula in medial view. D 14.03.97.10, whitened. Scale bar 5 mm. e - left ceratohyal in lateral view. BXM 074. Arrow indicates directio cranialis. Scale bar $5 \mathrm{~mm}$. f - right ceratohyal in medial view. BXM 074. Arrow indicates direction cranialis. Scale bar 5 mm. Abbreviations: grh - groove for truncus hyoideomandibularis facialis; hyc - hyomandibular canal; po - processus opercularis.

hyomandibula of Elonichthys crassidens which was figured by Štamberg (2010a: fig. 4B) has an angle of $158^{\circ}-160^{\circ}$ where the bone bends is also very similar (Schindler 2018a), but the antero-dorsal arm is twice the length of the ventral arm.
In medial view (Text-figs 7, 16d), a conspicuous wide furrow can be seen traversing across the centre of the hyomandibular dorsal arm. It is narrow at the point where the bone bends and the ventral arm is extended but it does 
not reach the ventral end of the hyomandibula. This may be an insertion point of the musculus adductor mandibulae. This groove on the hyomandibula was previously recorded by Long (1988: fig. 21B) in Howqualepis rostridens, but he figured the groove on the antero-dorsal arm only, and not at the point of the bend.

Ceratohyal. Right and left ceratohyals are well preserved on the slab BXM 074 together with numerous scattered bones of the skull. For this reason, the medial or lateral side of the ceratohyal was identified based on an earlier description of the bone in Pygopterus nielseni, Pteronisculus aldingeri and Moythomasia durgaringa (Aldiner 1937, Nielsen 1942, Gardiner 1984). The ceratohyal is slightly mediolaterally compressed, generally of rectangular shape in lateral and medial views. It expands posteriorly, narrows slightly anteriorly, and is conspicuously narrow in the anterior $1 / 3$ of the length (Text-fig. 16e, f). The anterior margin of the bone is straight, the posterior is oblique. A conspicuous groove on the lateral side (Text-fig. 16e) of the bone begins at the posterior end, it traverses anteriorly in the middle of the lateral surface of the bone, and bends slightly upwards where the bone constricts and leaves the bone on the dorsal margin immediately before the anterior end of the bone. The same groove was described in Moythomasia durgaringa (Gardiner 1984: fig. 106), Pygopterus nielseni (Aldinger 1937: fig. $41 \mathrm{~B}$ ) and others and is considered as being a groove for the afferent hyoidean artery. The identical shape in the ceratohyal and course of this groove for the afferent hyoidean artery have been recorded in Pteronisculus aldingeri (Nielsen
1942: fig. 43) and Progyrolepis speciosus (Štamberg 1991: fig. 21). On the contrary, the shape of the ceratohyal differs from this bone in Moythomasia durgaringa (Gardiner 1984: fig. 106) and Pygopterus nielseni (Aldinger 1937: fig. 41b). In the anterior third of the bone length where the course of the groove for the afferent hyoidean artery runs, the bone is clearly ossified. In medial view, the ceratohyal exhibits (Text-fig. 16f) massive perichondrally ossified bone with fine grooves indicating the ossification centre again in the area of bone constriction in the anterior third of the bone's length.

The symplectic is a robust bone connecting the hyomandibula to the ceratohyal in the sense of Nielsen (1942, 1949), Poplin and Véran (1996). It has the form of a short cylinder and can be observed behind the lower and upper jaws (Text-figs 7, 17a) or as an isolated bone in specimens D 09.11.96.11; D 14.03.98.19; BX 10.08.95. This short robust bone has two dorsally supporting columns terminating in facets in medial view (Text-fig. 17a, b). The anterior column is broader than the posterior one, with a conspicuous groove passing vertically from the dorsal margin of the bone dividing it into two halves. The symplectic is slightly constricted mid height. The ventral end of the bone is not divided and is slightly convex. There is a suggestion of articular facets on the anterior and posterior edges of the convex ventral end. The described symplectic is not well preserved, but the shape with probable articular facets on the dorsal and ventral ends indicates that the symplectic is the interconnection between the hyoid and palatoquadrate

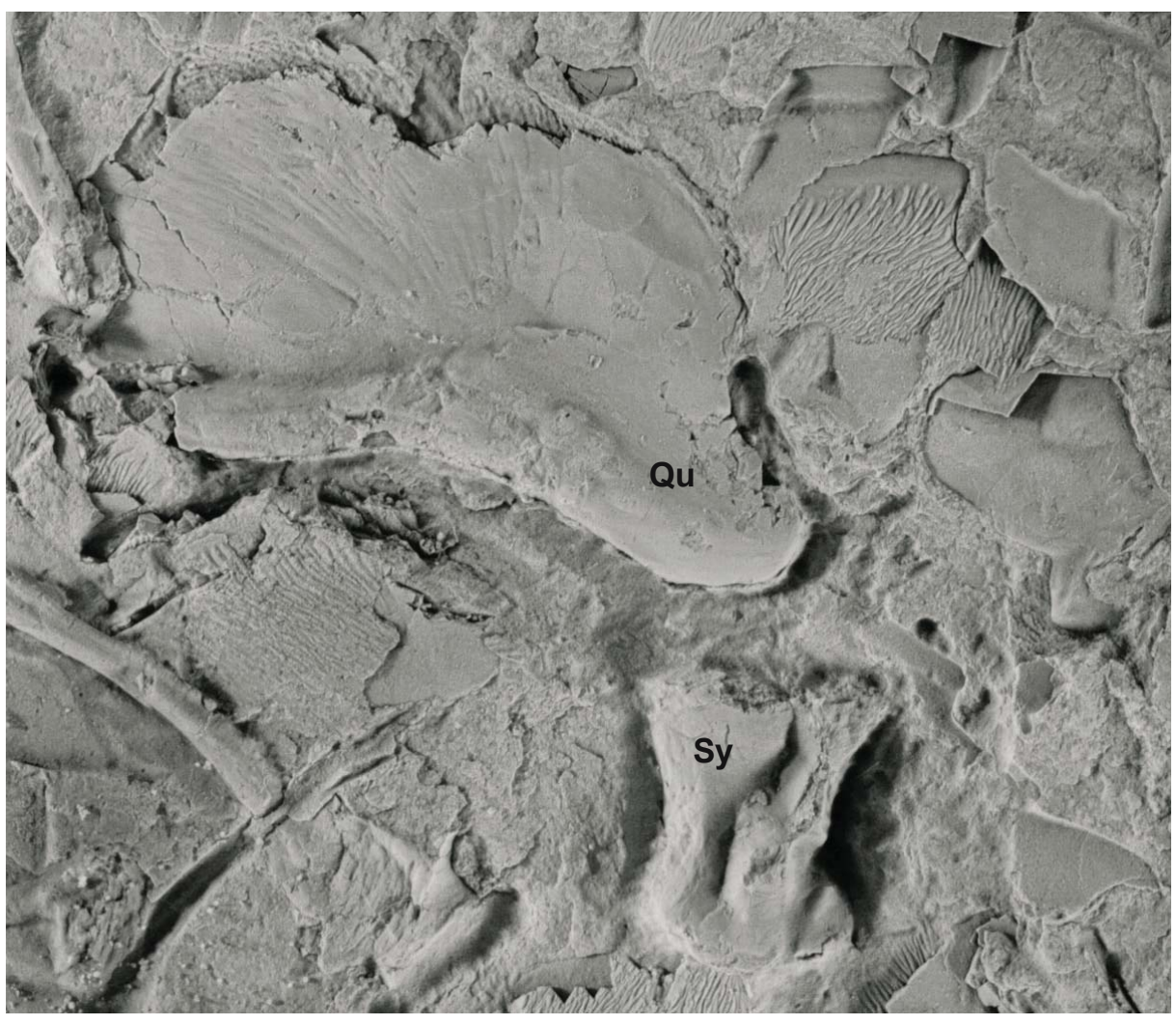

a

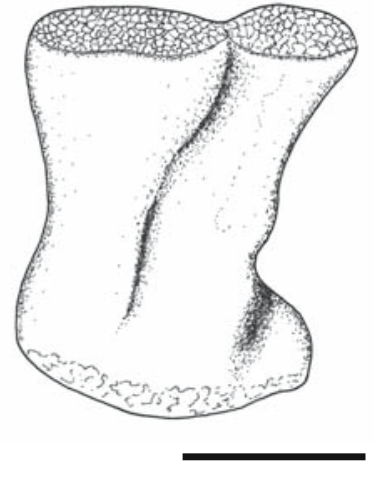

b

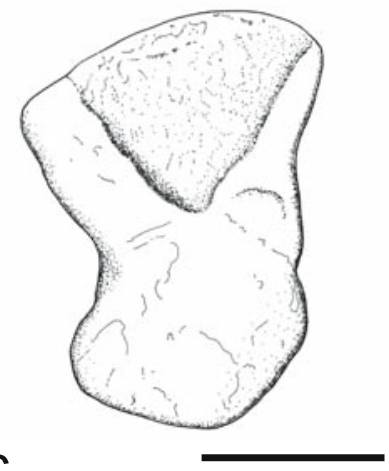

C

Text-fig. 17. Progyrolepis heyleri PopLIN, 1999. a - right palatoquadrate and symplecticum in medial view. BX 10.08.95, whitened. Scale bar $5 \mathrm{~mm}$. b - right symplecticum in medial view. BX 10.08.95. Scale bar $5 \mathrm{~mm}$. c - left symplecticum in lateral view. D 14.03.98.19. Scale bar $5 \mathrm{~mm}$. Abbreviations: $\mathrm{Sy}$ - symplectic; Qu - quadrate. 
arches. The above described symplectic varies greatly from that of Cheirolepis canadensis and "Pygopterus" degeeri after Véran (1988: figs 7, 8), Pteronisculus after Lehman (1952: fig. 35B) or Pteronisculus aldingeri after Nielsen (1942: fig. 42). The symplectic in Cheirolepis canadensis is of triangular shape in lateral view and in the other above mentioned species the symplectic is relatively narrow.

Opercular apparatus. The antoperculum, operculum, suboperculum and branchiostegal rays were distinguished among the dermal bones of the opercular apparatus.

The antoperculum itself was not found in the studied material. Its existence was suggested by the unsculptured anterior margin of the operculum (Text-fig. 18a, b) in specimen D 01.01.96.2. Based on the unsculptured anterior margin of the operculum, the triangular shape of the antoperculum can be deduced. It is dorsoventrally elongated, reaching to nearly $1 / 2$ the length of the operculum anterior margin from its dorsal end and wedged between the operculum and preoperculum. It is clear that this bone is not attached to the hyomandibula, and must be considered to be the antoperculum in the sense of Gardiner et al. (2005).

The operculum is preserved in several specimens (D 01.01.96.2; D 17.08.96.4; BX 10.03.96). It is rectangular, conspiucuously elongated in a dorso-ventral direction, with a slightly obtuse dorsoanterior angle (Text-figs $18 \mathrm{a}-\mathrm{c}$, $20)$. It is approximately 3 times deeper than it is long and 2.5-3 times deeper than the depth of the suboperculum. The operculum is significantly inclined anteriorly to the axis of the body, at an angle of $25^{\circ}-30^{\circ}$. The ventral corners of the operculum are rounded, and the anterior margin is straight but slightly concave. The posterior margin of the operculum is slightly convex. It is laterally sculptured by closely arranged vermicular ridges in the ventral third of the surface, the ridges being long and mostly parallel to the ventral margin of the bone. Along the anterior and posterior margins are ridges running parallel to these margins, in the central area of the surface are short vermicular ridges combined with tubercles. An unsculptured narrow area along the dorsal part of the anterior margin in specimen D01.01.96.2 was overlapped by the antoperculum. The operculum overlaps the supracleithrum posteriorly and the suboperculum ventrally.

The shape of the operculum is markedly different from the operculum of Progyrolepis speciosus as described by Stamberg (1991). The operculum of Progyrolepis speciosus is also elongated in dorso-ventral direction, but does not have a rectangular shape, the sloping of the ventro-anterior part of the bone forms a space for the triangular epipreoperculum, which in Progyrolepis heyleri is absent. These differences in the composition of the opercular apparatus can be attributed to evolution of the skull from Upper Carboniferous (Gzhelian) times when P. speciosus existed, to the occurrence of $P$. heyleri (Lower Permian, Asselian or Sakmarian). The shape of the operculum can also be variable to some extent as was described by Štamberg (2010a) in Rhabdolepis saarbrueckenensis in which one specimen had an operculum which was significantly narrower in the ventral direction while the neotype of $R$. saarbrueckenensis has a parallelogram shaped operculum (Gardiner 1963). Similar conclusions also resulted from Schindler's study (2018b) of Rhabdolepis macropterus which was found to also have a parallelogram shaped operculum (Schindler 2018b: figs 2, 3) which significantly narrows ventrally (Schindler 2018b: fig. 1). The shape and position of the operculum in Progyrolepis heyleri is similar to the parallelogram shaped operculum in Rhabdolepis macropterus. An antoperculum is also present in $R$. macropterus but it extends up to $4 / 5$ of the depth of the operculum (Schindler 2018b: figs 2, 3). The difference is in the absence of an accessory operculum in $P$. heyleri in contrast to its presence in $R$. macropterus. The operculum of $P$. heyleri differs significantly from that in Watsonichthys pectinatus or Cosmoptychius striatus (AgAssiz, 1835) as described by Gardiner (1963) where the operculum distinctly narrows ventrally and an accessory operculum is present.

A suboperculum is well preserved in D 01.01.96.2; D 14.03.97.12; D 17.08.96.4. It is approximately square in shape with prolonged anteroventral corner (Text-fig. $18 \mathrm{a}, \mathrm{b}, \mathrm{d}, \mathrm{e})$. The bone is shorter in the dorsal part than in its ventral part. The suboperculum has a straight anterior border, convex posterior border, and is slightly undulating dorsally and concave ventrally. The ossification centre lies in the ventral third of the bone near to its anterior border. Sculpture is preserved only on part of the bone and consists of closely spaced vermicular ridges mostly parallel to the dorsal, posterior and ventral margins of the bone (Textfig. $18 \mathrm{~d}$, e). Along the dorsal border the bone is without sculpture and was overlapped by the operculum, the ventral margin of the suboperculum overlaps the dorsal margin of the first branchiostegal ray. The suboperculum touches anteriorly the ventral portion of the preoperculum, and it overlaps the ventral part of the supracleithrum and dorsal part of the cleithrum posteriorly (Text-fig. 20). The shape of the suboperculum is very similar to that described (Štamberg 1991) in Progyrolepis speciosus.

Branchiostegal rays. A complete set of branchiostegal rays was not found preserved, but several branchiostegal rays can be seen in specimens D 01.01.96.2 (Text-fig. 18a, b) and BX 31.07.97.1 (Text-fig. 18f), and isolated branchiostegal rays are preserved in D 04.10.98.5 and BX 31.10.97.1. The branchiostegal rays are anteroposteriorly elongated, but are not excessively narrow. In the posterior region they are 2.3 times deeper than in the anterior, and are rounded anteriorly and posteriorly. It can be assumed that about 10 to15 branchiostegal rays formed this part of the skull during the life of the animal. Conspicuous sculpture on the lateral surface of the branchiostegal rays consists of tubercles and short ridges vermicularly twisted. Along the ventral margin of the rays are long ridges parallel with the ventral border of the bone. Along the dorsal margin is a strip of bone without any sculpture which was overlapped by the ventral margin of the above branchiostegal ray.

Components of the branchial arches are preserved only as isolated bones, and there is no obvious relationship between them or their position on the skull.

Dermal bones of the shoulder girdle. The posttemporal, supracleithrum, cleithrum and clavicle form the dermal components of the shoulder girdle.

The posttemporal is preserved in D 08.02.98.10.4/4 and BX 04.11.97.17. The bone is oval in shape, elongated in a mediolateral direction, and slightly narrower medially (Text-fig. 19g). Specimen D 08.02.98.10.4/4 contains a 

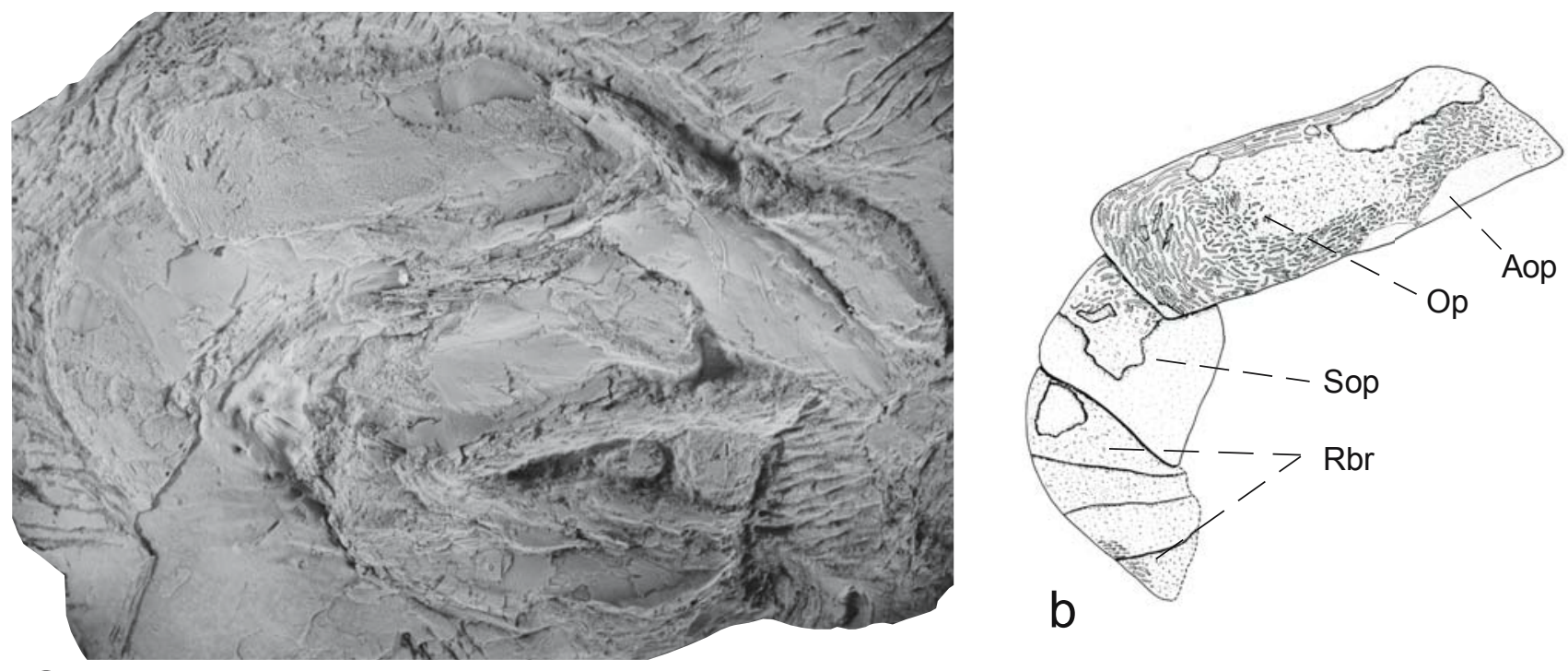

Aop

a
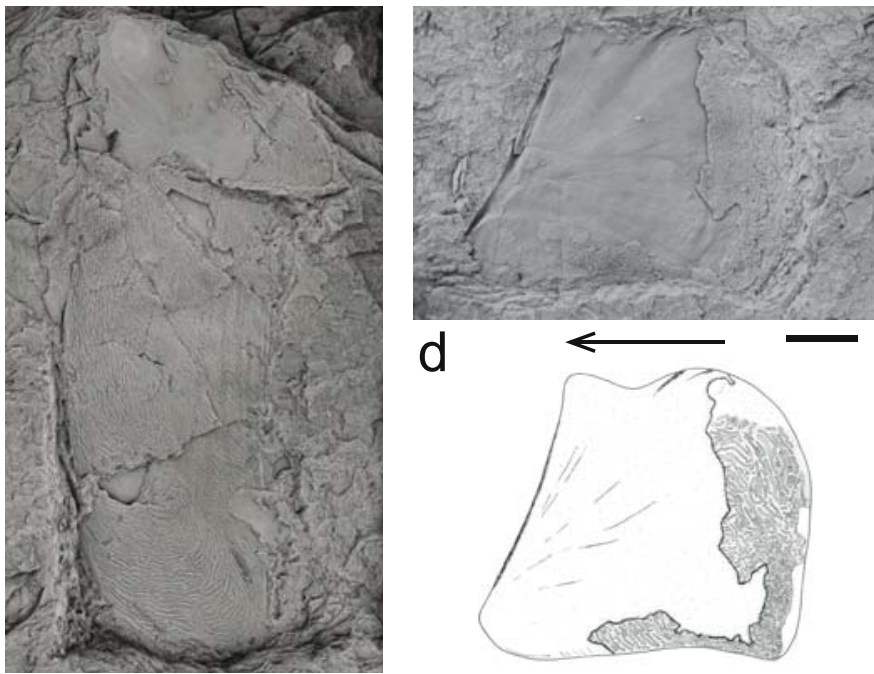

d

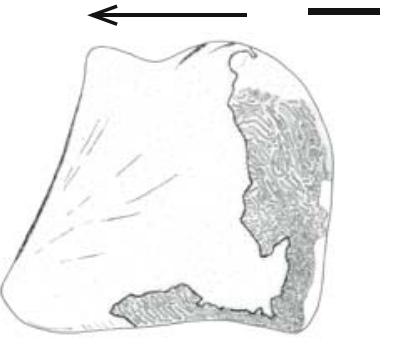

C

e

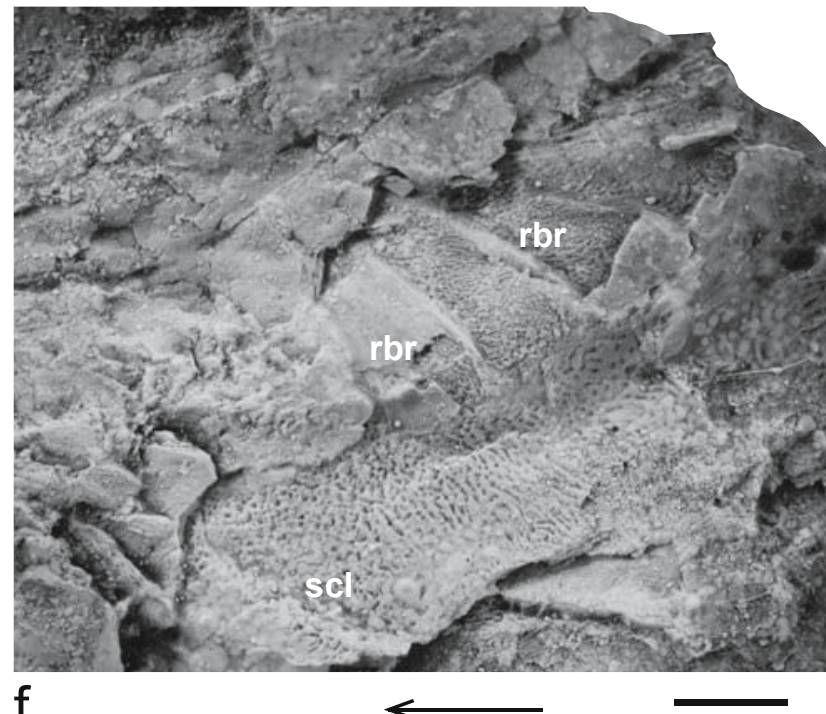

Text-fig. 18. Progyrolepis heyleri Poplin, 1999. a, b - photograph and drawing of right opercular and palatomaxillary apparatus in lateral view. D 01.01.96.2, whitened. Scale bars $5 \mathrm{~mm}$. c - right operculum in lateral view. D 17.08.96.4, whitened. Arrow indicates directio cranialis. Scale bar $5 \mathrm{~mm}$. d, e - photograph and drawing of the left suboperculum in lateral view. D 14.03.97.12, whitened. Arrow indicates direction cranialis. Scale bars $5 \mathrm{~mm}$. f - four branchiostegal rays in lateral view. BX 31.07.97.1. Arrow indicates direction cranialis. Scale bar 5 mm. Abbreviations: Aop - antoperculum; Op - operculum; Rbr - branchiostegal rays; Sop - suboperculum.

fragment of the dorsal side of the bone with sculpture consisting of conspicuous ridges. The rest of the specimen shows the imprint of the ventral surface of the posttemporal with a conspicuous lateral sensory line in the anterolateral corner. The lateral sensory line most likely passed from the lateral extrascapular and continued across the posttemporal, traversing across the dorsal side of the supracleithrum. The shape of the posttemporal corresponds to that in Progyrolepis speciosus, Elonichthys krejcii and Acrolepis gigas (Frič, 1877) (Štamberg 1991, 2010a), it differs however from the triangular posttemporal in Pteronisculus (Nielsen 1942) and rectangular posttemporal in Mimipiscis toombsi (Gardiner 1984).

The supracleithrum is a large oval shaped bone, elongated in a dorso-ventral direction with a large dorsal process (Text-fig. 19a, e). The supracleithrum in specimen D 10.08.95 7/7 in Text-fig. 19e shows the bone in medial view; it is $65 \mathrm{~mm}$ high, including the dorsal process which is $10 \mathrm{~mm}$ high. The bone is longest in its dorsal third and measures $26 \mathrm{~mm}$. In the ventral direction, it is slightly narrower, and the ventral end is rounded. The posterior border of the supracleithrumm is moderately convex with a notch at the point where the lateral sensory canal traverses from the supracleithrum to the scales of the body. The anterior border of the supracleithrum is straight in the dorsal two thirds, but in the ventral $1 / 3$ it is conspicuously concave and is considerably narrower. The lateral sensory canal traverses across the dorsal third of the bone and is clearly traceable from the medial as well as the lateral sides. It passes to the supracleithrum from the posttemporal on its dorsal border, immediately anteriorly to the dorsal process on the supracleithrum. It then passes diagonally in a ventroposterior direction and traverses from the supracleithrum to the scales one third of the way down its 

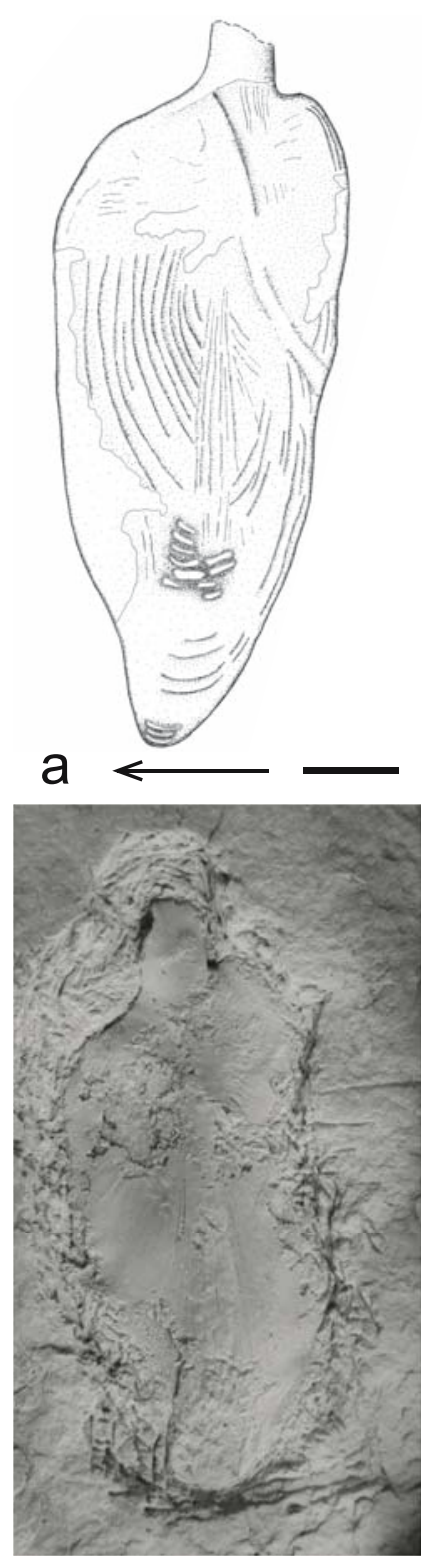

e

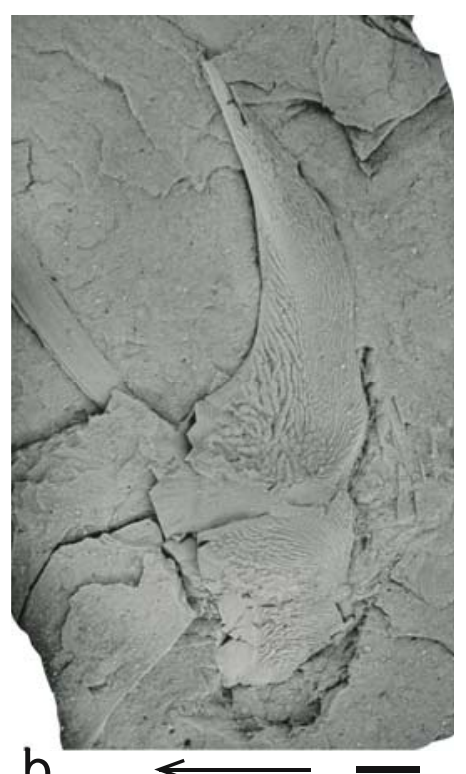

b

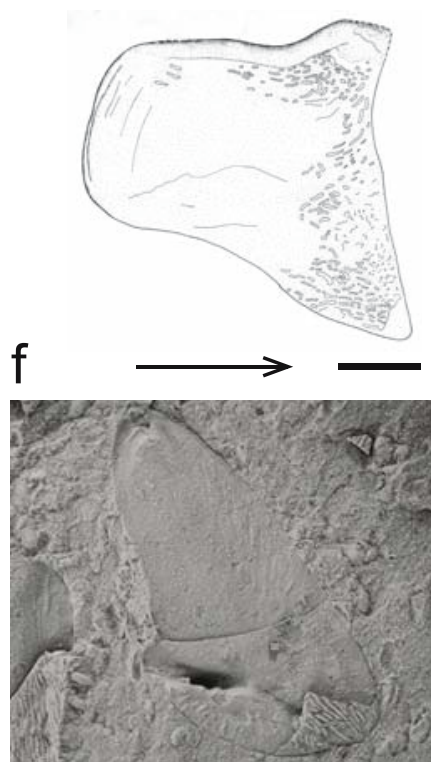

g
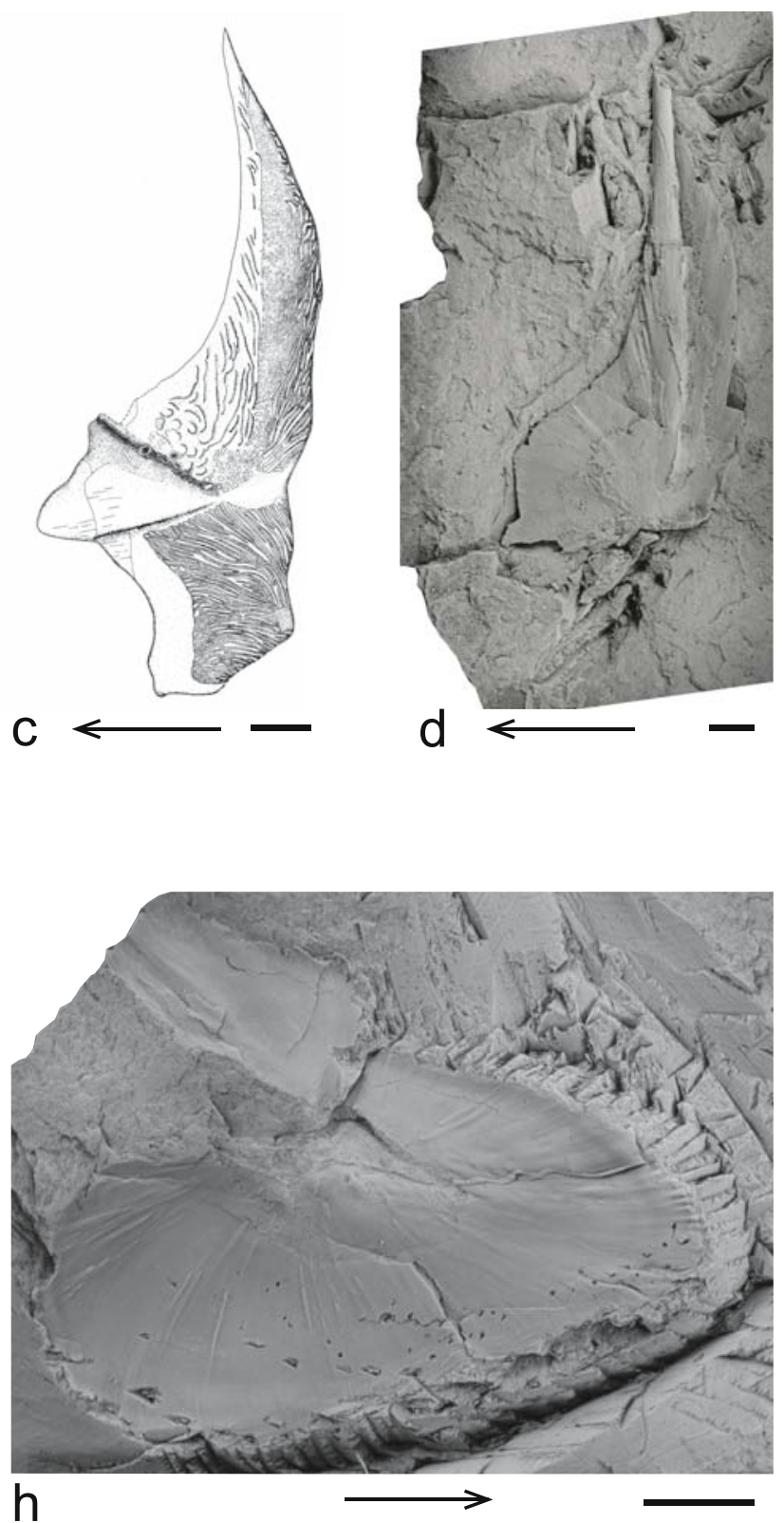

Text-fig. 19. Progyrolepis heyleri Poplin, 1999. Arrows indicate directio cranialis. Scale bars 5 mm. a - drawing of the left supracleithrum in lateral view. BX 07.09.97. b, c - photograph and drawing of the left cleithrum in lateral view. BX 03.06.97.1, whitened. $\mathrm{d}$ - right cleithrum in medial view. BX 04.11.97.1, whitened. e - right supracleithrum in medial view. D 10.08.95.7/7, whitened. $\mathrm{f}$ - drawing of the right suboperculum in lateral view. MHK 82828. $\mathrm{g}$ - left posttemporal in dorsal view. D 08.02.98.10.4/4, whitened. $\mathrm{h}$ - left clavicle in medial view. BX 04.11.97.1, whitened.

posterior margin. The lateral surface of the supracleithrum exhibits conspicuous sculpture. Ridges arranged in an anteroventral direction prevail in the dorsal quarter of the bone, the rest of the bone is ornamented with long ridges running parallel to the anterior and posterior borders of the bone. These ridges bend ventrally along the ventral margin of the supracleithrum. There is no sculpture on the dorsal process of the supracleithrum which is overlapped by the posttemporal. In medial view, distinct reinforcement of the bone is visible in the location of the supracleithrum dorsal process which continues ventrally through the centre of the bone up to the ventral margin and gradually weakening. The process on the dorsal border of the supracleithrum is outstanding. This type of process, which is overlapped in its normal position by the lateral margin of the posttemporal, is common for example in Amblypteridae and Aeduellidae, but is absent in Mimipiscis toombsi (Gardiner 1984).

The cleithrum is a dorsoventrally elongated and laterally convex bone which borders the branchial cavity posteriorly and forms support for the insertion of the pectoral fin ventroposteriorly. The cleithrum (Text-fig. 19bd) in lateral view is divided into two branches, namely the dorsal branch which is almost vertical and the ventral branch which is almost horizontal. The dorsal branch is triangular in shape, twice higher than it is long and significantly elongated and tapering to the tip dorsally. A conspicuous convex edge crosses the cleithrum from its dorsal point arcuately ventroanteriorly, and the cleithrum bends medially alongside this edge. The edge forms the posterior border of the branchial cavity. During the life of the animal, this space 


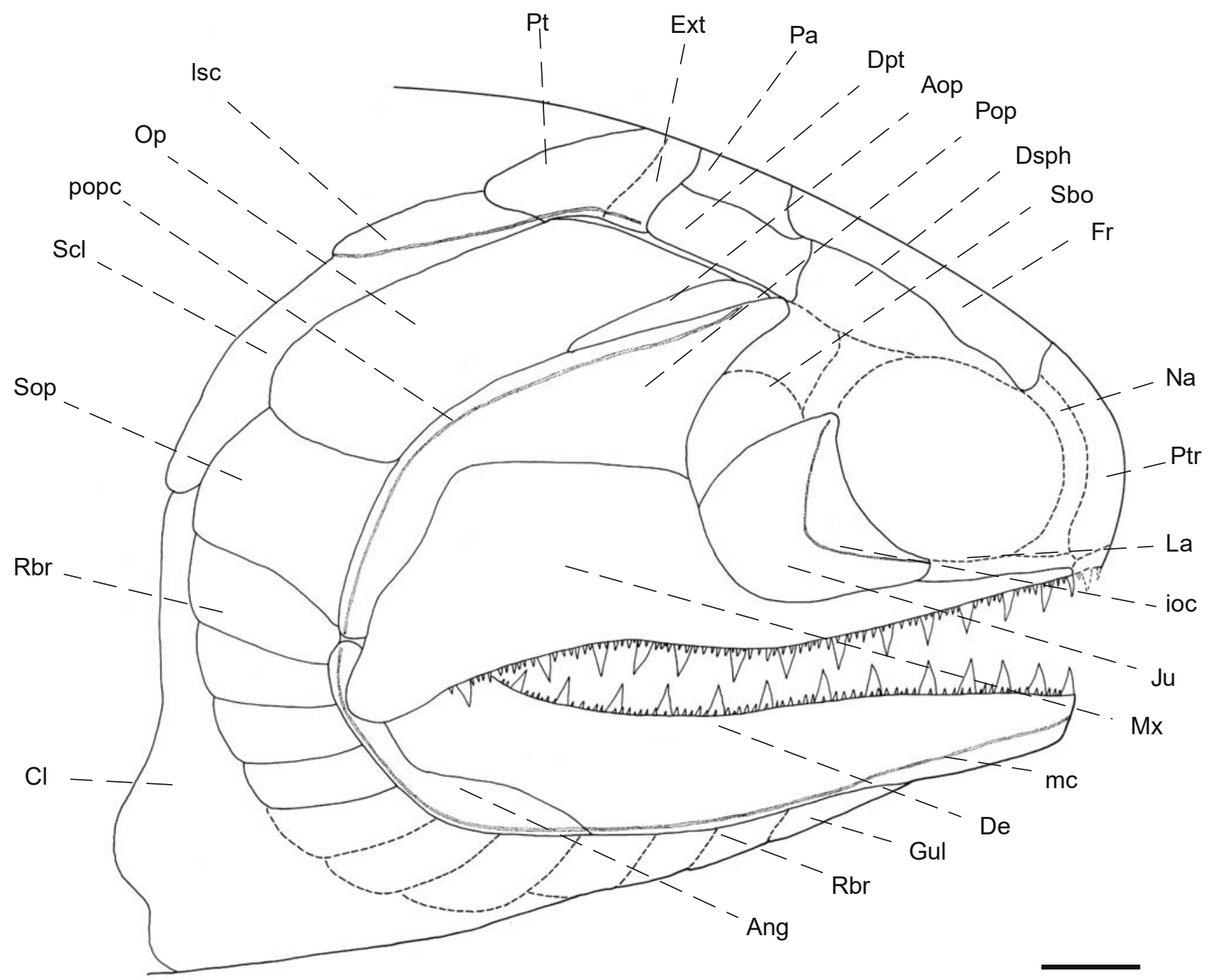

Text-fig. 20. Progyrolepis heyleri Poplin, 1999. Restoration of the skull in lateral view. Bones that are not clearly retained on the skull are marked with dashed lines. Scale bar represents 10 mm. Abbreviations: Ang - angular; Aop - antoperculum; Cl - cleithrum; De - dentalosplenial; Dsph - dermosphenotic; Dpt - dermopterotic; Ext - extrascapular; Fr - frontal; Gul - gular lateral; ioc - infraorbital canal; Ju - jugale; La - lachrymal; lsc - lateral sensory canal; mc - mandibular canal; Mx - maxilla; Na - nasal; Op - operculum; Pa - parietal; Pop - preoperculum; popc - preopercular canal; Pt - posttemporal; Ptr - postrostral; Rbr - branchiostegal ray; Sbo - suborbital; Scl - supracleithrum; Sop - suboperculum.

was overlapped by the suboperculum and branchiostegal rays. The posterior border of the dorsal branch is strongly convex with a shallow notch in the ventral part of the margin at the point where the pectoral fin would be connected. A conspicuous reinforcement of the dorsal branch is visible in medial view and it passes from the dorsal tip of the cleithrum ventroanteriorly up to the ossification centre of the bone which lies at the point where the cleithrum bends, i.e. in the area of transition between the dorsal branch and ventral branch of the cleithrum. The lateral surface of the vertical branch is conspicuously ornamented with ridges and tubercles demonstrating three types of sculpture. The lateroanterior region of the bone which forms the posterior border of the branchial cavity exhibits crests arranged in a parallel fashion with minute denticulation on the top edges. The crests are not densely positioned. The edge of the dorsal branch, passing from the dorsal apex of the branch anteroventrally, on the contrary exhibits densely spaced tubercles and short ridges. The extended lateral surface of the vertical branch behind its edge, shows densely positioned long moulds which are arranged predominantly in a dorsoventral direction.

The ventral branch of the cleithrum is almost square in outline (Text-fig. 19b, c), and nearly horizontal. The ventral surface of the branch is conspicuously sculptured with long ridges closely positioned in an anteroposterior direction. The anterior margin of the cleithrum is without sculpture and is overlapped by the clavicle.

The clavicle is a large bone. Similarly to the cleithrum, it consists of two parts, namely the horizontally oriented ventral division and vertically oriented dorsal division (Textfig. 19h). The horizontal ventral division of the clavicle is triangular in outline in ventral view. It is relatively short in anteroposterior dimension and bluntly terminates anteriorly. The medial margin of the clavicle's horizontal division is almost straight, not undulating, rounded posteriorly and 
slightly convex ventrally. The horizontal division is laterally bent dorsally and continues to the vertically orientated dorsal division. The vertical dorsal division is also triangular in outline in lateral view and forms a process dorsolaterally. There is no sculpture on the large anterodorsal surface which is smooth and covered by the branchiostegal rays.

The short wide clavicle of Progyrolepis heyleri differs significantly from the clavicle of a number of other actinopterygians. Devonian actinopterygians Mimipiscis toombsi and Moythomasia durgaringa have a clavicle with an anteriorly elongated and pointed horizontal branch (Gardiner 1984), similarly the clavicle is significantly elongated in Cheirolepis trailli (Pearson and Westoll 1979).

Pectoral fin. The pectoral fin is preserved in D 12.10.95.11; D 12.10.95.8; BX 31.07.97.1; D 03.10.95.8, and they represent fins from young and adult specimens. The fin consists of at least 15 lepidotrichia which are segmented in addition to the lepidotrichia of the leading edge of the fin. The leading pectoral fin lepidotrichium is unsegmented, with small fringed fulcra on its anterior border. The fringed fulcra are firmly connected to the leading pectoral fin lepidotrichium (Text-fig. 22a).

Pelvic fin. The base of the pelvic fin extends over eight scale rows, and the fin consists of at least 20 lepidotrichia (D 17.09.96.4). The lepidotrichia are segmented (Text-fig. 22b), and some segments bear two or three grooves. The longest lepidotrichia on BX 31.05.99.49 have 15 segments.

Caudal fin. The ventral lobe of the caudal fin consists of 18 segmented lepidotrichia. These segments bear lengthwise grooves (D 14.03.38.23).

Scales. The complete shape of the body is not visible in any specimen. Numerous fragments including D 03.10.95.8; D 05.06.96(3); D 05.09.98(3); D 11.11.95.7; D 12.10.95.8;

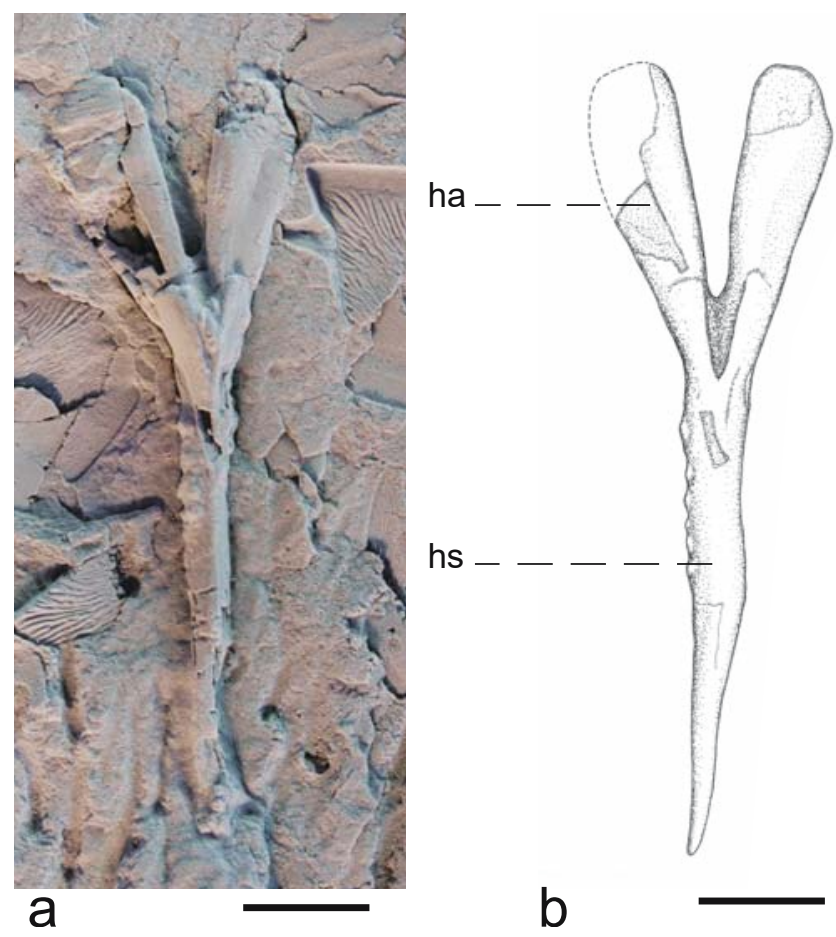

Text-fig. 21. Progyrolepis heyleri Poplin, 1999. a, b - photograph and drawing of the fragment of the haemal arche of the axial skeleton. BX 10.08.95, whitened. Scale bar $5 \mathrm{~mm}$. Abbreviations: ha - haemal arch; hs - haemal spine.
D 12.10.95.11; D 12.11.95(7); D14.03.38 (23); D 17.09.96(4); D 18.12.96(7); D 20.03.99.6; BX 03.11.98(1); BX 31.05.99.49; BX 31.07.97.1 demonstrate only part of the body and the fins. Fragments of the body document a spindle shaped body extending to $70 \mathrm{~cm}$ of the total body length, with the head occupying $1 / 5$ of the total body length. Below the lateral sensory line are 26 scales, between the ridge scale of the anal fin and lateral sensory line (BX 31.05.99.49), and the same row has 16 scales above the lateral sensory line. The lateral sensory line is traceable from the posterior margin of the supracleithrum up to the caudal peduncle, and the pores of the lateral sensory line are not visible on each scale in the line but more often on every third scale. The exposed side of the scale containing the pore is convex in the area in front of the pore (Text-fig. 23c, d). In addition to the lateral sensory line, there is another sensory line developed in the dorsal part of the anterior region of the body. The dorsal accessory sensory line is visible only on several scales and there are 11 scales between the main lateral sensory line and this dorsal accessory sensory line. The complementary dorsal sensory line is known in Howqualepis rostridens (Long 1988). Blot (1966) described a dorsal sensory line in Paramblypterus decorus (EGERTON, 1850) and Heyler (1969) in Aeduella blainvillei (AgAssiz, 1833). The body is covered with scales arranged in transverse scale rows. There are about 9 scale rows between the supracleithrum and pelvic fin base, 26 scale rows between the supracleithrum and the anal fin base, and 46 scale rows between the supracleithrum and the base of the caudal fin. There are about 50 scale rows between the supracleithrum and the line of inversion in the caudal peduncle. The shape of the scales varies depending on the location on the body, similarly as recorded in other palaeoniscoid fishes (Text-figs 22, 23). The sculpture on the exposed face of the scales changes simultaneously. The scales in the anterior part of the body along the lateral sensory line are of oblong shape, twice higher than they are long (Text-figs 22e, 23f). Significant ridges of ganoine traverse across the scales, and protrude at the posterior border of the scale to form serrations. There are up to 16 short spines on the posterior border of the scales. The scales located more posteriorly on the body have a rhombic shape (Text-fig. 23a). The scales possess diagonal ridges. The longest ridge passes diagonally from the anterodorsal corner to the posteroventral corner of the scale, and it terminates in a dental form process on the posterior margin of the scale. This is the second or third dental form process on the posterior border of the scale, counting from the ventral corner of the scale. This long ridge divides the lateral surface of the scale into the anteroventral and posterodorsal halves. The arrangement of ridges on the two halves is different. Six to seven ridges are recognizable on the anteroventral region of the scale. These ridges start at the anterior margin of the scale anastomosis posteriorly, and terminate in one or two depressions. The posterodorsal half of the scale has one or two ridges which start at the anterodorsal corner of the scale, branch posteriorly, and terminate in eight or more depressions. The scales above the pelvic fin are shallow; they are five times longer than they are deep. Long ridges pass along the ventral margin of the scales where the ridge along the ventral margin of the scale is conspicuously wide (Text-fig. 23d, h). Peg and socket articulation is well developed. Scales overlap each other but 

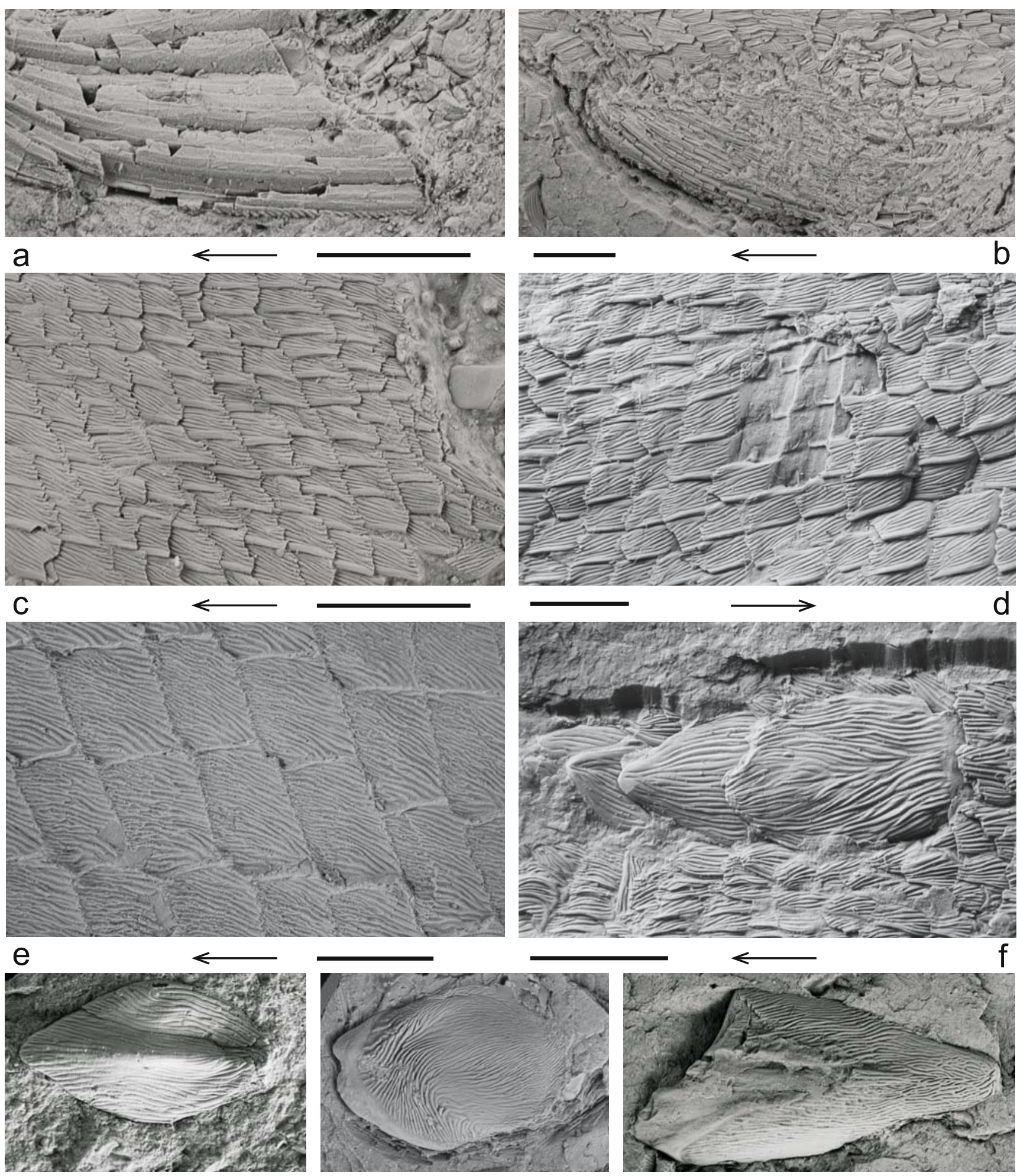

g

$\mathrm{h}$

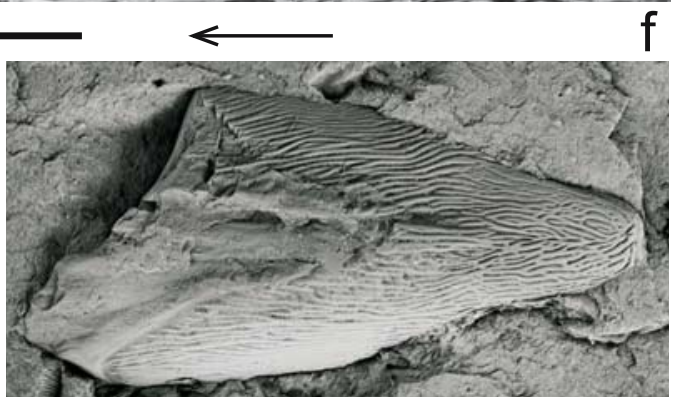

i

$\leftarrow$

Text-fig. 22. Progyrolepis heyleri Poplin, 1999. Scale bars 5 mm. Arrows indicate directio cranialis. Whitened. a - lepidotrichia from the anterior border of the pectoral fin. D 03.10.95.8. $\mathrm{b}$ - pelvic fin. BX 31.05.99.49. $\mathrm{c}$ - the scales from the area between the pelvic and anal fins. D 18.12.96. $d$ - the scales from the area below the lateral sensory line above the pelvic fin. BX 03.11.98.1. $\mathrm{e}-$ the scales from the anterior region of the body above the lateral sensory line. D 05.09.98. $\mathrm{f}$ - ridge scales in front of the dorsal fin base. BX 03.11.98.1. $\mathrm{g}$ - single ridge scale conspicuously convex forming a keel in front of the anal fin. D 14.03.97. $\mathrm{h}$ - flat paired ridge scale in front of the anal fin. BXM 80. $\mathrm{i}$ - large basal fulcra from the dorsal rim of the caudal peduncle. D 12.11.95.7.

mutual overlapping of scales in an anteroposterior direction is limited, being from $1 / 8$ to $1 / 9$.

The microsculpture on the scales is formed by microtubercles arranged in the same direction as the ridges. The microtubercles have an elliptical base, are antero-posteriorly elongated (Text-figs 23b, 24), and are more elongated and less numerous than in "Elonichthys" sp. (Štamberg 2016b: figs $8 \mathrm{C}, 9 \mathrm{~B}, \mathrm{D})$. Microtubercles are typical for ganoine 

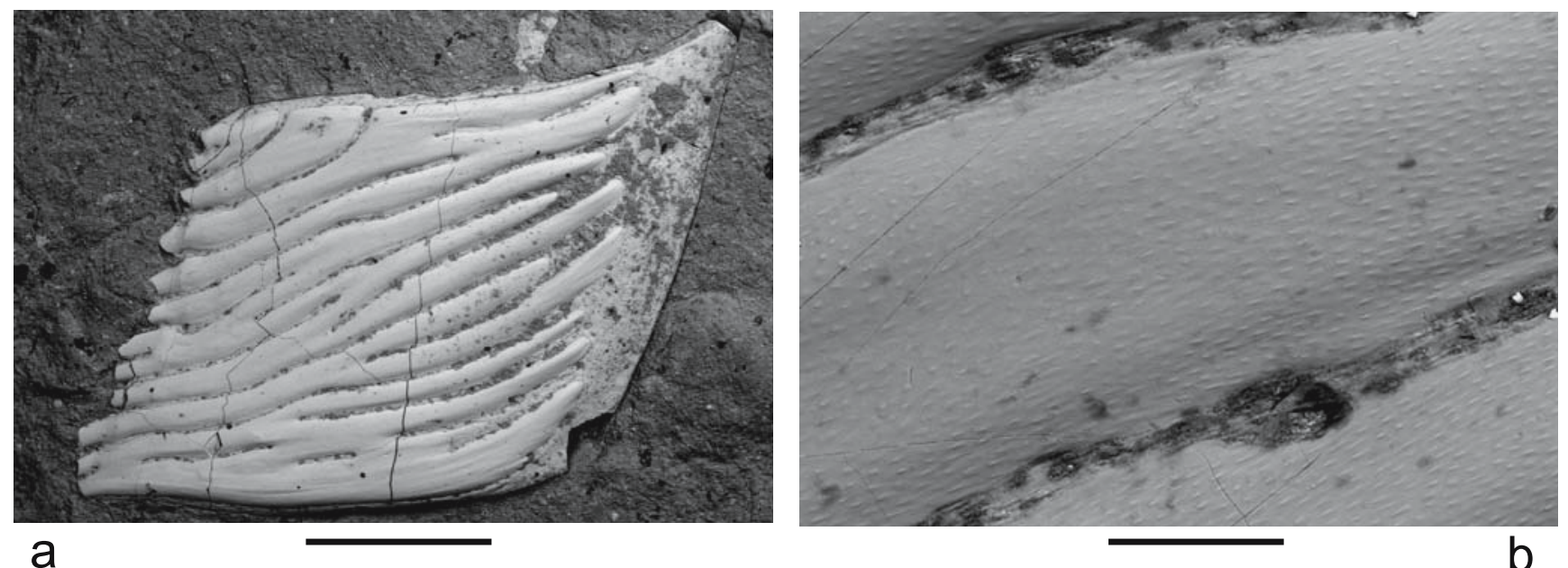

a

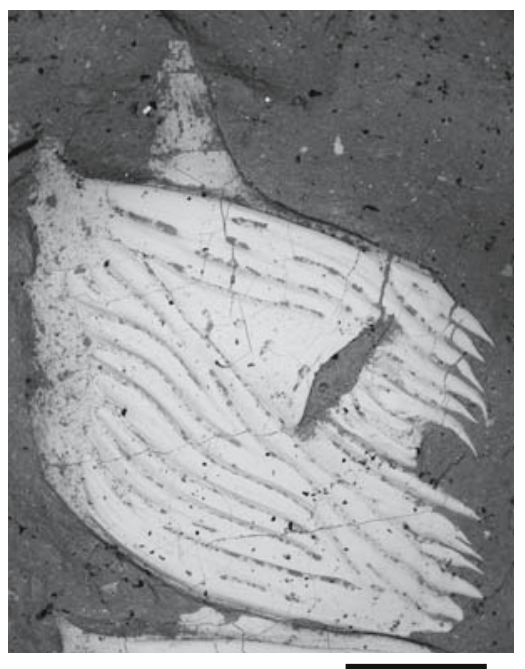

C
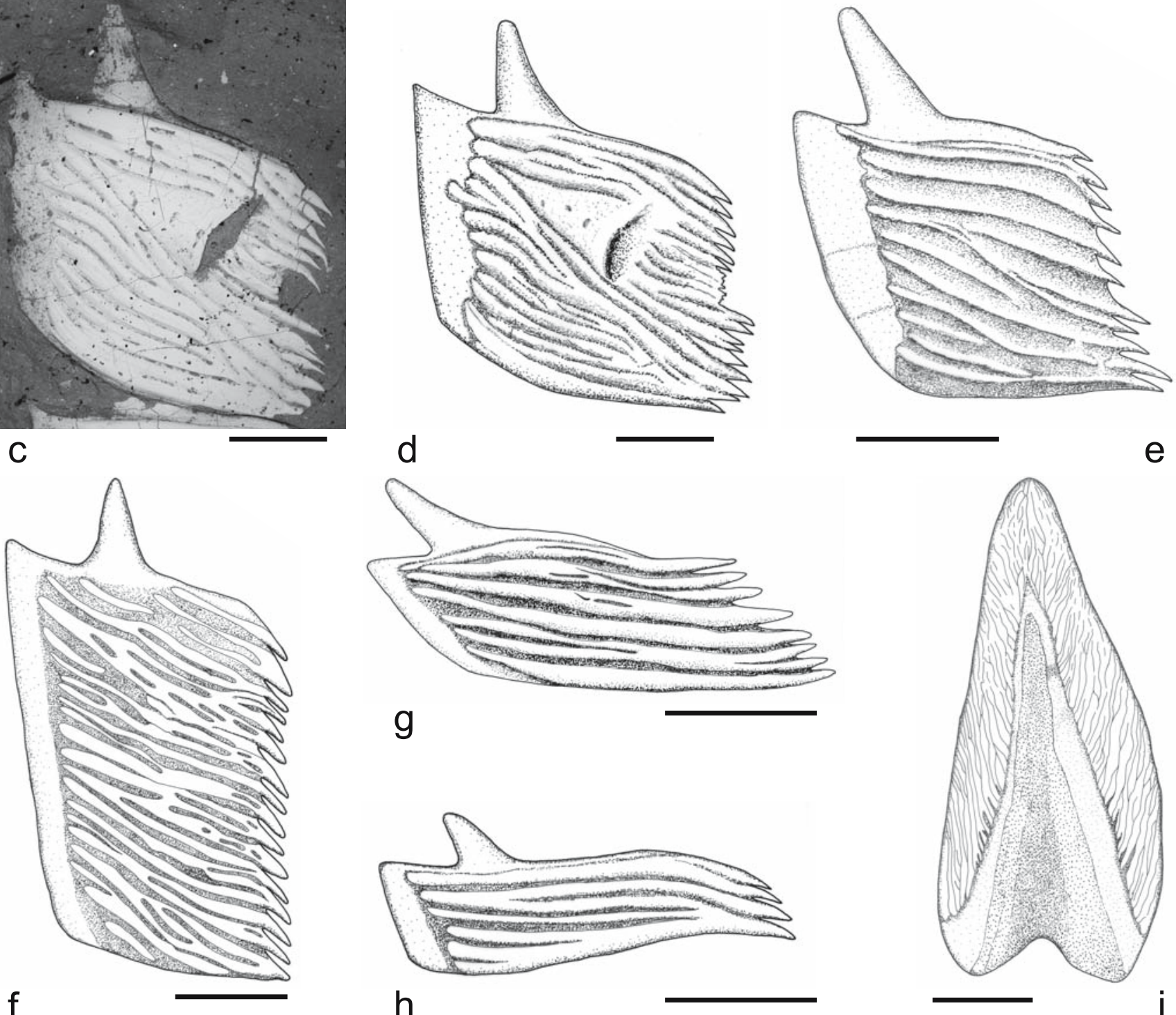

d

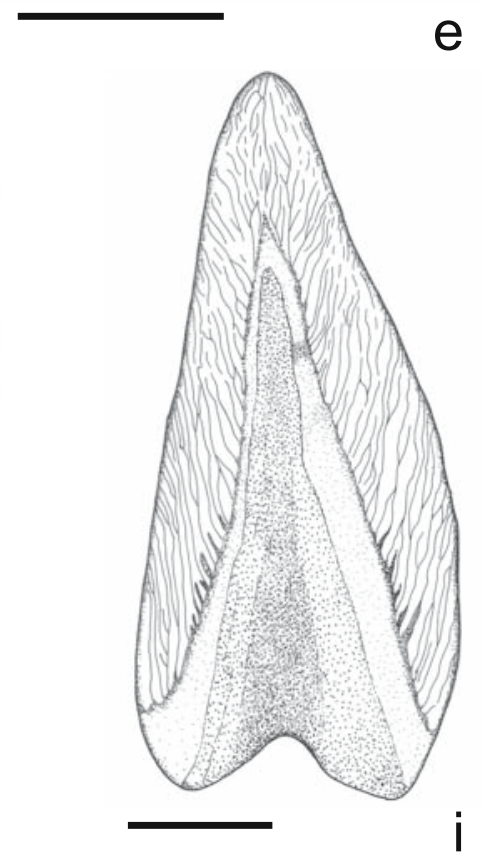

Text-fig. 23. Progyrolepis heyleri Poplin, 1999. a - a scale from the middle part of the lateral side of the body with conspicuous ridges arranged diagonally across the scale. MHK 82831, whitened. Scale bar $1 \mathrm{~mm}$. b-small tubercles which form the microsculpture on the scale have elliptical base, antero-posteriorly elongated, and are arranged diagonally in the same direction as the ridges on Text-fig. 23a. MHK 82831. Scale bars $100 \mu \mathrm{m}$. c, d - photograph and drawing of a scale with a pore of the lateral sensory line. D 08.02.98.10.4/4, whitened. Scale bar $1 \mathrm{~mm}$. e - drawing of a scale from the middle part of the lateral side of the body. D 04.11.95.10. Scale bar $1 \mathrm{~mm}$. $\mathrm{f}$ - drawing of a scale from the anterior region of the body above the lateral sensory line. D 05.09.98. Scale bar $1 \mathrm{~mm}$. $\mathrm{g}$ - drawing of a scale from the lateral side of the body between the lateral sensory line and the base of the pelvic fin. D 18.13.96.7. Scale bar $1 \mathrm{~mm}$. $\mathrm{h}$ - drawing of a scale from the abdominal region of the body in front of the pelvic fin. BX 31.05.99.49. Scale bar $1 \mathrm{~mm}$. i - large basal fulcra from the dorsal rim of the caudal peduncle. BX 28.01.99.8. Scale bar $5 \mathrm{~mm}$. 

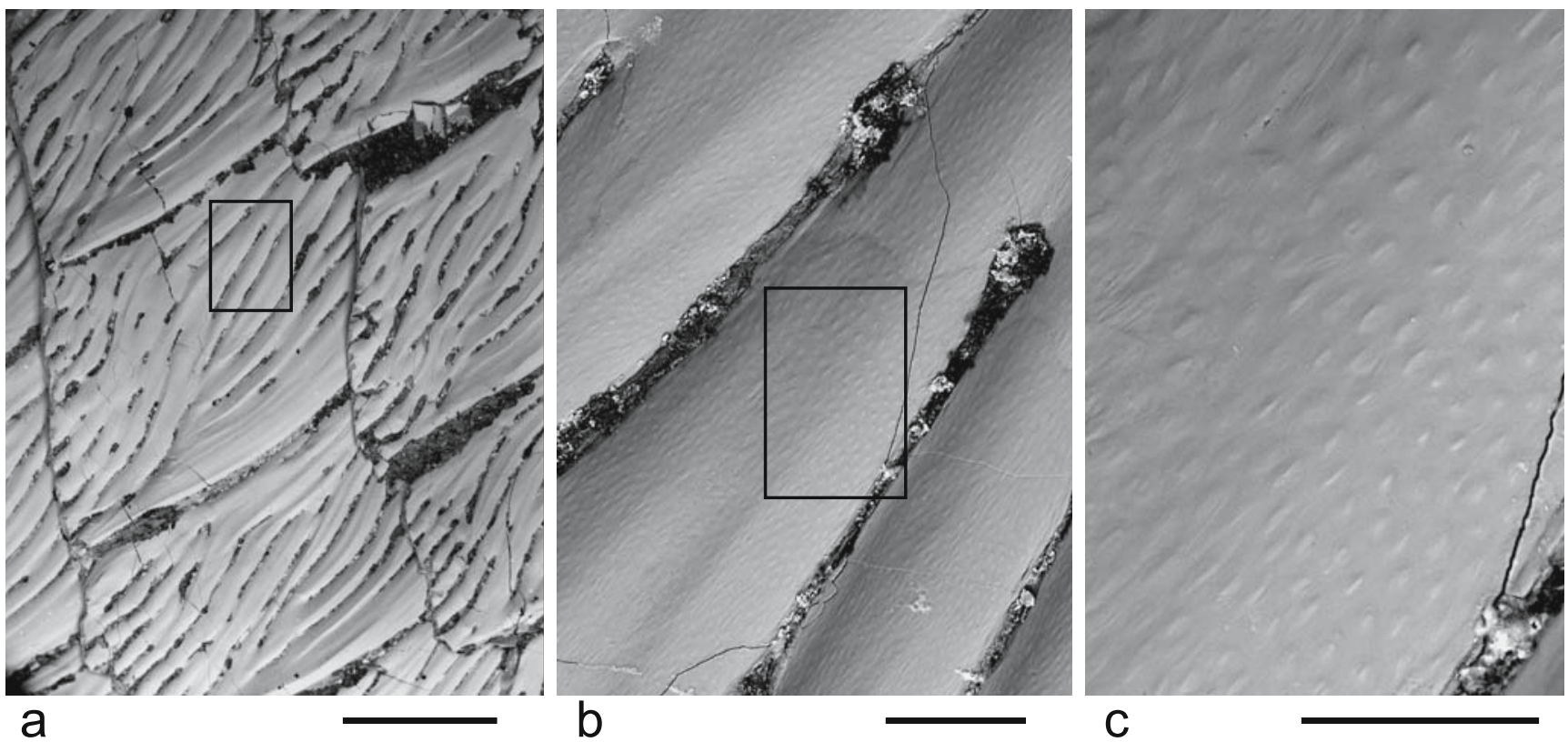

Text-fig. 24. Progyrolepis heyleri Poplin, 1999. Scales from the dorsal part of the body which exhibit ridges arranged diagonally across the scale plus microtubercles. MHK 82829. a - whole scales. The frame marks the view at b of this Text-fig. Scale bar $1 \mathrm{~mm}$. $b$ - sector of the surface with some ridges and microtubercles. Scale bar $100 \mu \mathrm{m}$. The frame marks the view at c. $c-s e c t o r$ of the surface with microtubercles slightly extended diagonally. Scale bar $50 \mu \mathrm{m}$.

(Schultze 2016), and they are also present in Palaeozoic actinopterygians Strepheoschema fouldenensis WhiтE, 1927 and Palaeoniscum freieslebeni BLAINVILLE, 1818 (Richter 1995), Spinarichthys dispersus (FrITSCH, 1894) (Štamberg 2016a) and Aeduella blainvillei (Text-fig. 34g, h).

Several specialised scales are developed in addition to the flank scales. Three or four large ridge scales precede the base of the dorsal fin. They bear sculpture consisting of conspicuous ridges arranged in an antero-posterior direction (Text-fig. 22f). Large ridge scales are also developed in front of the anal fin. Closest to the anal fin is a single large scale with a conspicuous ventral ridge that forms a keel (Textfig. 22g). Posterior to this large keeled scale are large paired flat scales (Text-fig. 22h). The ridge scales bear numerous ridges protruding posteriorly in several serrations. Large basal fulcra cover the dorsal and ventral border of the caudal peduncle (Text-fig. 22i). They extend in an antero-posterior direction and bear conspicuous ridges on their exposed surface and their medial surface which is overlapped by the preceding basal fulcra.

Conclusion to Progyrolepis heyleri. The decomposed bodies, isolated bones and scales produced a large quantity of new information about Progyrolepis heyleri. Knowledge regarding the jaws which are of vital importance for designation of this species (Poplin 1999) was greatly enhanced, including changes in the shape of the maxilla during ontogenesis. Completely new information about the construction of the palatoquadrate, dermal bones of the skull roof, opercular apparatus and the shoulder girdle was gained. Characteristics regarding the squamation were identified and described, including microsculpture on scales, and specialised scales in front of the fins. Some information was gained in regards to the bones of the rostral part of the skull, around the orbit, and the ventral portion of the operculo-gular series. A general understanding of the shape of the body was also formed. The study of the microsculpture on the teeth documents the same microsculpture in Progyrolepis heyleri as described by Fritsch (1895) in Progyrolepis speciosus, and there is no difference as proposed by Poplin (1999). Similarly, decoration on the anterior part of the maxillary plate is variable and cannot be considered a character that can discriminate Progyrolepis speciosus from Progyrolepis heyleri as assumed by Poplin (1999). The character which differentiates Progyrolepis speciosus from Progyrolepis heyleri is the shape of the operculum. It is oblong shape and there is an antoperculum in $P$. heyleri, whereas the operculum narrows ventrally and an epipreoperculum is present in Progyrolepis speciosus. The scales of $P$. heyleri are well preserved while the scales of $P$. speciosus are partly preserved in only one specimen, and therefore a thorough comparison of the two species is not possible as of yet.

The shape of the operculum, with a slender antoperculum limited to the dorsal border of the anterior margin of the operculum, suggests some convergence of Progyrolepis heyleri with Pygopterus nielseni, Nematoptychius greenocki and Cycloptychius. The shape of the parasphenoid and curved interfrontal suture do not fit in the original description of Pygopteridae submitted by Aldinger (1937). It is important to compare Progyrolepis heyleri with other large carnivorous fish such as Elonichthys and Rhabdolepis from European Permo-Carboniferous basins. The large jugal and form of the cheek bones figured by Schindler (2018a) in Elonichthys germari and Štamberg (1991) in "Elonichthys" krejcii demonstrate great similarity. In addition the border between the dermopterotic and dermosphenotic in Progyrolepis heyleri is in a more posterior location but remains anteriad to the border of the fronto-parietal. The dermosphenoticdermopterotic border in Rhabdolepis macropterus or 
"Elonichthys" krejcii is located posteriorly to the frontoparietal border (Štamberg 2010a, Schindler 2018b). The maxilla of Rhabdolepis macropterus has a slanting anterior margin which forms an angle of $20^{\circ}-29^{\circ}$ (Schindler 2018 b) with the ventral denticulated border of the maxilla, and in Elonichthys germari this angle is $45^{\circ}$ (Schindler 2018a). Progyrolepis speciosus and Progyrolepis heyleri demonstrate angles of $68^{\circ}-77^{\circ}$, and only juvenile specimens have a more oblique anterior margin and angle of around $40^{\circ}$. The arrangement of the dermal bones of the operculogular series in Progyrolepis heyleri differ significantly from those in Rhabdolepis macropterus or Rhabdolepis saarbrueckensis in which one or two accessory opercula are inserted between the operculum and suboperculum (Gardiner 1963, Štamberg 2010a, Schindler 2018b) and also from those in Elonichthys germari or "Elonichthys" krejcii in which the operculum narrows ventrally, and additionally a very deep first branchiostegal ray follows the suboperculum (Štamberg 2010a, Schindler 2018a).

\section{Aeduellidae Romer, 1945}

Type genus. Aeduella Westoll, 1937

In cluded s peci es. Aeduella blainvillei (AgAssiz, 1833); Bourbonnella guilloti HeYLER, 1967; Bourbonnella fourrieri POPLIN, 2001; Bourbonnella sottyi (HEYLER, 1977); Bourbonnella hirsuta ŠTAMBERG, 2007; Bourbonnella jocelynae Mickle, 2011; Decazella vetteri HeYler, 1964; Neslovicella rzehaki ŠTAMBERG, 2007; Neslovicella elongata Štamberg, 2010b; Platysella lallyi Heyler et Poplin, 1983; Platysella descusi Heyler et Poplin, 1983; Platysella poplinae Heyler, 2002; Puertollanichthys ritchiei FOREY et Young, 1985; Spinarichthys dispersus (FrITSCH, 1894); Westollia crassus (Pohlig, 1892)

\section{Genus Aeduella Westoll, 1937}

Ty p e s pecies. Aeduella blainvillei (Agassiz, 1833).

\section{Aeduella blainvillei (Agasssiz, 1833)}

Text-figs 25-35

Diagnosis. After Heyler (1969; emended). Body fusiform reaching a total length of $20 \mathrm{~cm}$. The parietal small and always longer than it is wide. The frontal large and wide; the width of the bone is 1.6-2 times its length. The dermosphenotic with prominent posterolateral process. Pentagon shaped rostro-postrostral with conspicuous tubercles on its outer surface. Orbit is large. The crescent shaped anterior supraorbital inserted between the orbit and the nasal. Variability in the fusion of the parietal. Supraorbital may or may not be fuse with the dermosphenotic and may or may not reach to the nasal. There may be five or six extrascapulars, many supraorbitals, and horizontal fragmentation of the preoperculum. The maxilla with triangular maxillary plate which is low posteriorly. The ratio of the length of the maxilla to its depth is on average from 3 to 3.5. The operculum and suboperculum are very high, ornamented with flat tubercles on their surface. Very oblique suture between the operculum and suboperculum. The suboperculum has conspicuously sloping and concave dorsal margin. Only one branchiostegal ray is present. The medial gular is elongated in anteroposterior direction, and it is significantly more slender anteriorly. The cleithrum is of ovoid shape. There maybe five or six extrascapulars. The pectoral fin inserts on the scaly lobe. The anal fin has a short base. Segments of lepidotrichia are short, but large with sigmoid sutures. The main lateral line extends, in some specimens, to the caudal inversion which is gradual. A short accessory lateral line is present dorsally behind the skull. Scale count:

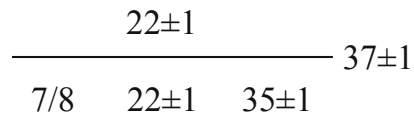

Description. The material consists of specimens ranging from juveniles with a total length of $36 \mathrm{~mm}$ (D 26.11.95.2) to adults with a length of $180 \mathrm{~mm}$ (D 20.03.99.6). The trunk is dorsally arched, and its greatest depth is at the level just anterior to the pelvic fin. The ratio between total length of the body in the adult specimens to height is about 3.2 , and the ratio between total length of the body to head length is about $5-5.5$. The skull is rounded anteriorly, but does not extend anteriorly.

Head. Snout. To date, a complete rostral region of the skull has not been found, but isolated bones or fragments are evident in the available material. The rostro-postrostral (in the sense of Heyler 1969) is in the shape of a pentagon (Text-fig. 26c) as in D 11.02.95.6; MHK 82787. The posterior margin of the bone is convex, and it fills the space created anteriorly in the concave anterior border of the right and left frontals. The outer surface of the rostro-postrostral is decorated with tubercles, which in the anterior region of the bone are very conspicuous but further back are less pronounced. The posterior part of the rostro-postrostral is without sculpture. In specimens from Buxières-lesMines, laterally from the rostro-postrostral is the anterior supraorbital which is well preserved in several specimens (D 20.03.99/6; MHK 82784; MHK 82782; MHK 82787). This bone, which is wedged between the nasal and the orbit, is crescent shaped and the posterior concave border abuts the orbit anteriorly (Text-fig. 26d). The bone is conspicuously decorated with long ridges parallel to the posterior border of the bone. In the anterior direction the ridges are gradually shortened, and only isolated tubercles are present along the anterior border. The bone forms several conspicuous sinuses anteriorly where the pores of the supraorbital sensory canal are located. These supraorbital sensory canal pores are on the boundary line between the anterior supraorbital and nasal. The studied specimens from Buxières-les-Mines also contain bones which represent a coalescence of the nasal with the anterior supraorbital. A coalescence of the nasal with the anterior supraorbital is usual. The anterior supraorbital was previously described as the antorbital by Westoll (1937: figs 2, 4) in Aeduella blainvillei from Muse. The anterior supraorbital is also present in many specimens of Aeduella blainvillei from Muse described and figured by Heyler (1969). Heyler (1969) considered this bone to be the nasal, but several figures (Heyler 1969: figs 48, $50,56,57,91,92)$ demonstrate the anterior supraorbital combined with the nasal to produce a single unit. The rostral region composed of the medial rostro-postrostral, paired nasal, and paired anterior supraorbital was described by 


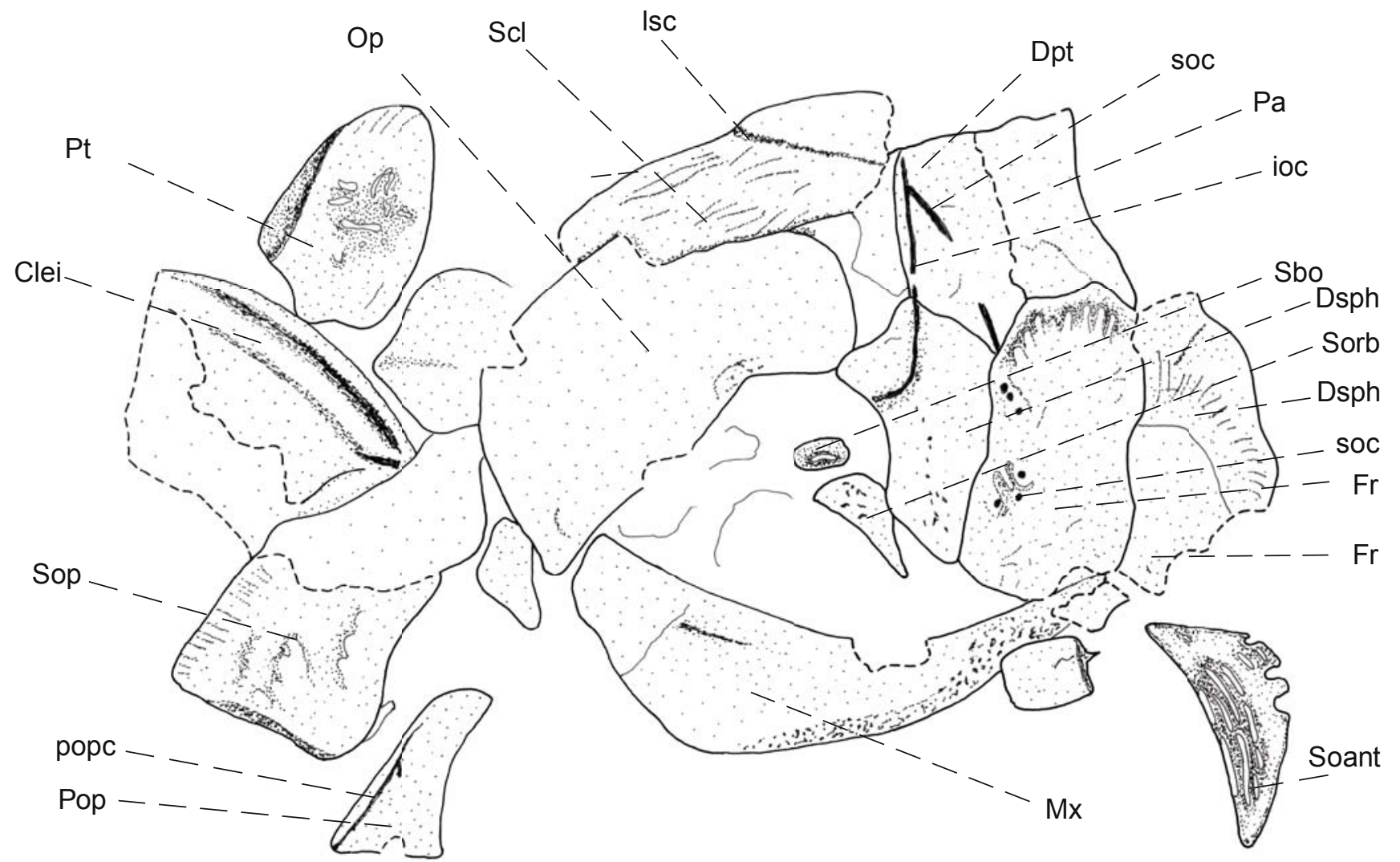

a

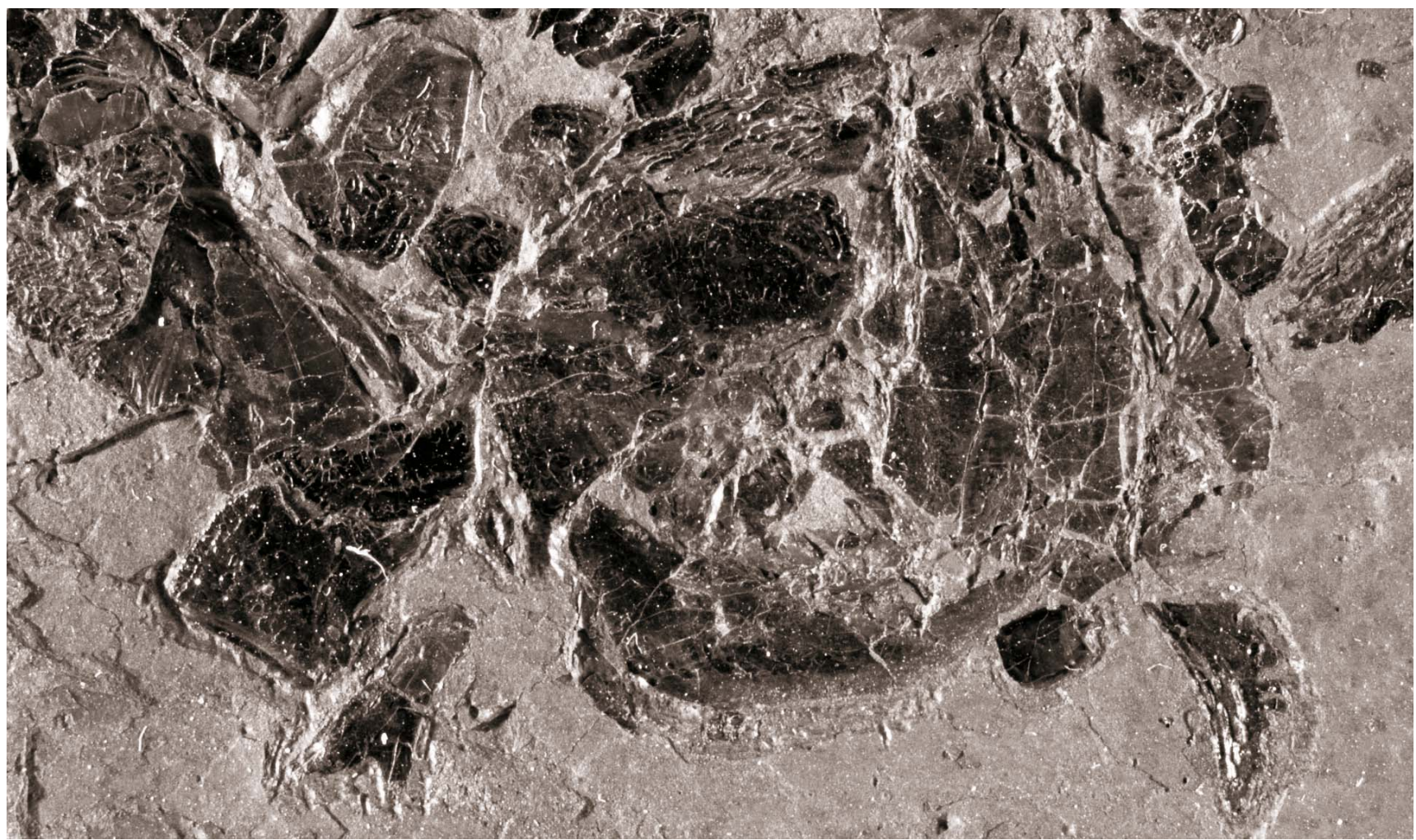

b

Text-fig. 25. Aeduella blainvillei (Agassiz, 1833). a, b - drawing and photograph of the skull. MHK 82784. Scale bars 5 mm. Abbreviations: Clei - cleithrum; Dsph - dermosphenotic; Dpt - dermopterotic; Fr - frontal; ioc - infraorbital canal; lsc - lateral sensory canal; Mx - maxilla; Op - operculum; Pa - parietal; Pop - preoperculum; popc-preopercular canal; Pt - posttemporal; Sbo - suborbital; Scl - supracleithrum; Soant - anterior supraorbital; Sorb - supraorbital; soc - supraorbital canal; Sop - suboperculum. 
Štamberg $(2007,2010 b)$ in aeduellids Bourbonnella hirsuta, Neslovicella rzehaki and Neslovicella elongata. It is clear that the configuration of the rostral region bones in Aeduella blainvillei from Muse, Aeduella from Buxières-les-Mines, Bourbonnella hirsuta, Neslovicella rzehaki and Neslovicella elongata is similar to the rostral region in Amblypteridae ROMER, 1945. Blot (1966) described the anterior supraorbital in addition to the nasal and postrostral in the rostral region in Paramblypterus decorus, Heyler (1969) and Štamberg (1976) in Paramblypterus rohani (Heckel, 1861), Dietze (1999) in Paramblypterus duvernoy (Agassiz, 1833) and Štamberg (2013b) in Amblypterus latus (Agassiz, 1833). The coalescence of the anterior supraorbital with the nasal to produce one unit was documented in Paramblypterus duvernoy by Dietze (1999).

Skull roof. The frontal, parietal, dermosphenotic, dermopterotic and the extrascapular series which form the skull roof are preserved in several specimens.

The oblong frontal is the largest bone in the skull roof (Text-figs 25, 26a, b, g). The frontal is relatively wide; the width of the bone is 1.6-2 times its length (MHK 82784, MHK 82787 , D 04.11.05.11). The interfrontal suture is straight, the lateral suture which borders with the dermosphenotic is also straight or slightly undulating anteriorly (Text-fig. 26a, b, g). The short posterior part of the frontal's lateral suture borders with the dermopterotic. The posterior border of the frontal has a conspicuous notch at the point where the supraorbital canal passes from the frontal to the dermopterotic. The anterior border of the frontal slopes medially, and this concave area is filled by the rostro-postrostral. The exposed surface of the frontal is ornamented with inconspicuous flat tubercles. The infraorbital sensory canal crosses over the frontal from the lateral corner of the frontal's anterior margin in a posterior direction close to its lateral margin, and traverses to the dermopterotic in the lateral part of the frontal's posterior margin. (Text-fig. 26a, g).

The parietal (Text-figs 25, 26a, b, e, f) is narrow, oblong in shape, and is always longer than it is wide (MHK 82785; MHK 82804; D 04.11.05.19). The borders of the parietal are almost straight, not conspicuously undulating. The right and left parietals are always narrower than the frontals. The sculpture on the exposed surface is not conspicuous, and is formed by flat tubercles as on the frontal. Two sensory pit lines, namely the medial pit line and posterior pit line are very prominent on the bone posterolaterally. The dermopterotic borders the parietal laterally and a series of extrascapular bones posteriorly.

A triangular dermosphenotic borders the frontal laterally (Text-figs 25, 26a, b). It is extended in an antero-posterior direction, narrows anteriorly and is posteriorly (BX 07.09.97; D 04.11.05.19; MHK 82784; MHK 82787). The bone has a characteristic shape, and it forms a prominent process posterolaterally. The infraorbital sensory canal passes to the dermosphenotic from the dermopterotic, and subsequently bends ventrolaterally and traverses across the lateral process of the dermosphenotic, around the posterior border of the orbit.

The dermopterotic is oblong in shape. An extentsion in the antero-posterior direction is preserved on specimens $\mathrm{D}$ 04.11.05.19, BX 07.09.97; MHK 82784; MHK 82787. The courses of the sensory canals on the dermopterotic are of great importance. The infraorbital sensory canal traverses from the dermosphenotic in a posterior direction along the lateral border of the dermopterotic, and from there it traverses posteriorly to the bones of the extrascapular series. The continuation of the supraorbital sensory canal is also present as well as the infraorbital sensory canal. The supraorbital sensory canal traverses from the frontal, and it anastomoses with the branch of the supraorbital sensory canal in the posterior area of the dermopterotic (Text-fig. 25).

The series of extrascapular bones is partly preserved in $\mathrm{D}$ 04.11.05.19. They form a strip of small bones posterior to the parietals and dermopterotics. It is not possible to distinguish the exact number of extrascapular bones. The infraorbital canal runs from the dermopterotic to the extrascapulars and it divides into the supratemporal branch interconnected with the infraorbital sensory canals of the right and left sides of the skull and continues posteriorly to the supracleithrum as the lateral sensory line.

The formation of the skull roof and course of the sensory canals are a distinguishing feature of the Aeduellidae. A parietal which narrows markedly towards the frontal was figured by Heyler (1969) for both Aeduella blainvillei, Decazella vetteri and Bourbonnella guilloti, by Štamberg (2007) in Neslovicella rzehaki and Bourbonnella hirsuta and by Štamberg (2010b) in Neslovicella elongata. The shape of the dermosphenotic is also a distinguishing feature. The dermosphenotic in Carboniferous and Permian actinopterygians is usually triangular in shape, narrows anteriorly and broadens in a posterior direction so that the bone is widest at its posterior part (Amblypterus, Paramblypterus). The dermosphenotic of Aeduellidae have a similar shape, but with a prominent ventro-lateral process along the infraorbital sensory canal, and a narrowing posteriorly. The dermosphenotic extends less than the frontal, but in dimensions it is the second largest bone of the skull roof. It differs from the bones of the skull roof in the Amblypteridae in which the dermopterotic is the second largest bone in the skull roof after the frontal. Previously Westoll (1937) and Heyler (1969) stressed the importance of the course of the sensory lines in Aeduellidae. Supraorbital sensory canal passes across the frontal and traverses onto the dermopterotic where it anastomoses with the infraorbital canal. However, the passing of the supraorbital canal from the frontal to the parietal is the most common condition in other Permo-Carboniferous actinopterygians. The supraorbital sensory canal marks not only the pit line on the dermopterotic anteriorly, but it continues and posteriorly anastomoses with the infraorbital canal (Text-fig. 25). The termination of the supraorbital sensory canal was described (Heyler 1969, Poplin and Dutheil 2005) as being a pit line only. It is now clear that the canal anastomoses with the infraorbital sensory canal on the dermopterotic similarly as in Decazella vetteri (Heyler 1969). Only two pit lines, namely the middle and posterior, are present on the parietal, whereas in most PermoCarboniferous actinopterygians the presence of three pit lines is documented on the parietal. These typical features of the sensory lines in Aeduellidae were documented in the material from Buxières-les-Mines. The same supraorbital canal course as in Aeduellidae was described byBlot (1966), Heyler (1969), Štamberg and Zajíc (1994) and Štamberg (2016a) in the family Igornichthyidae HeYLER, 1977. 

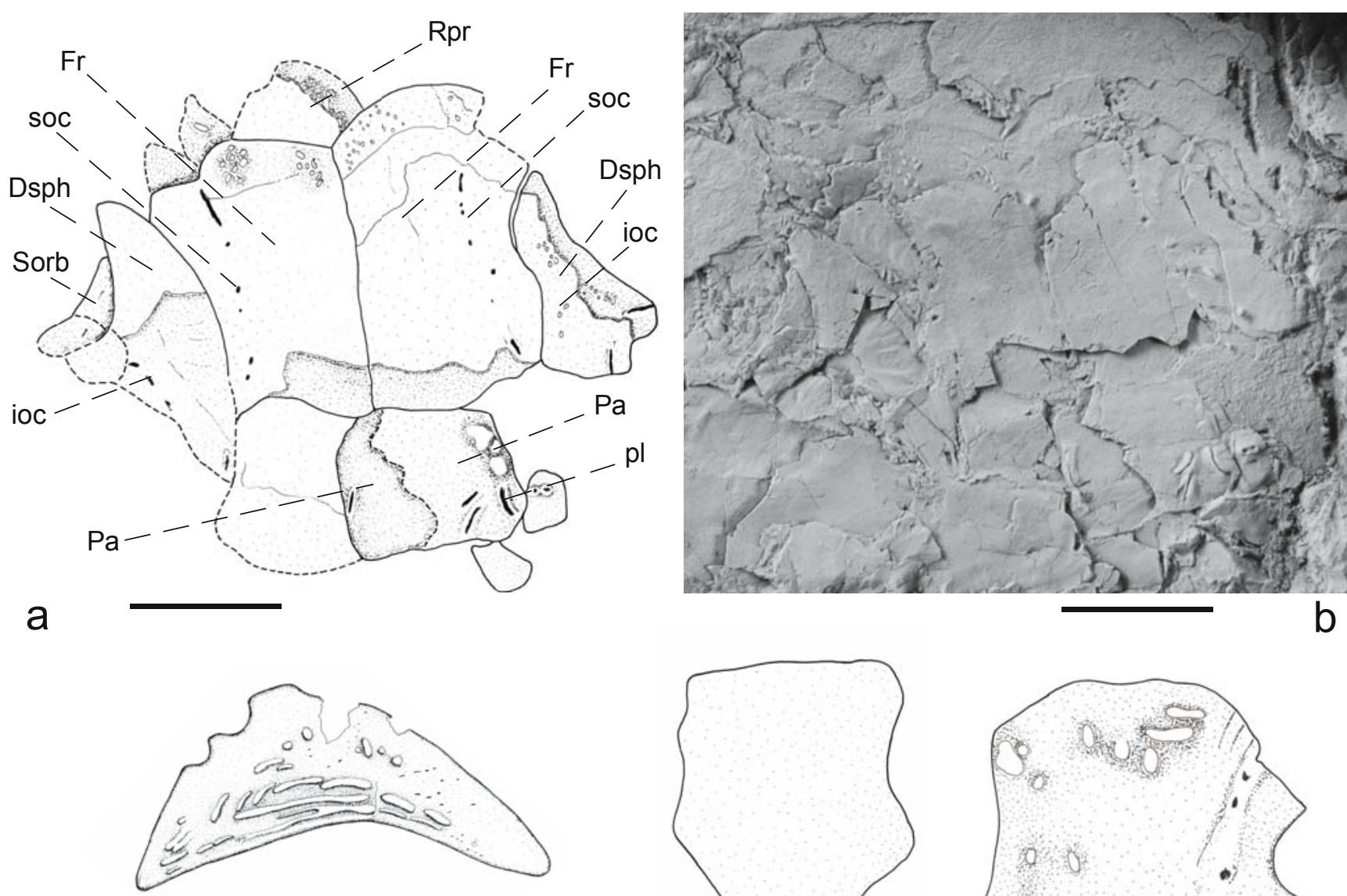

d
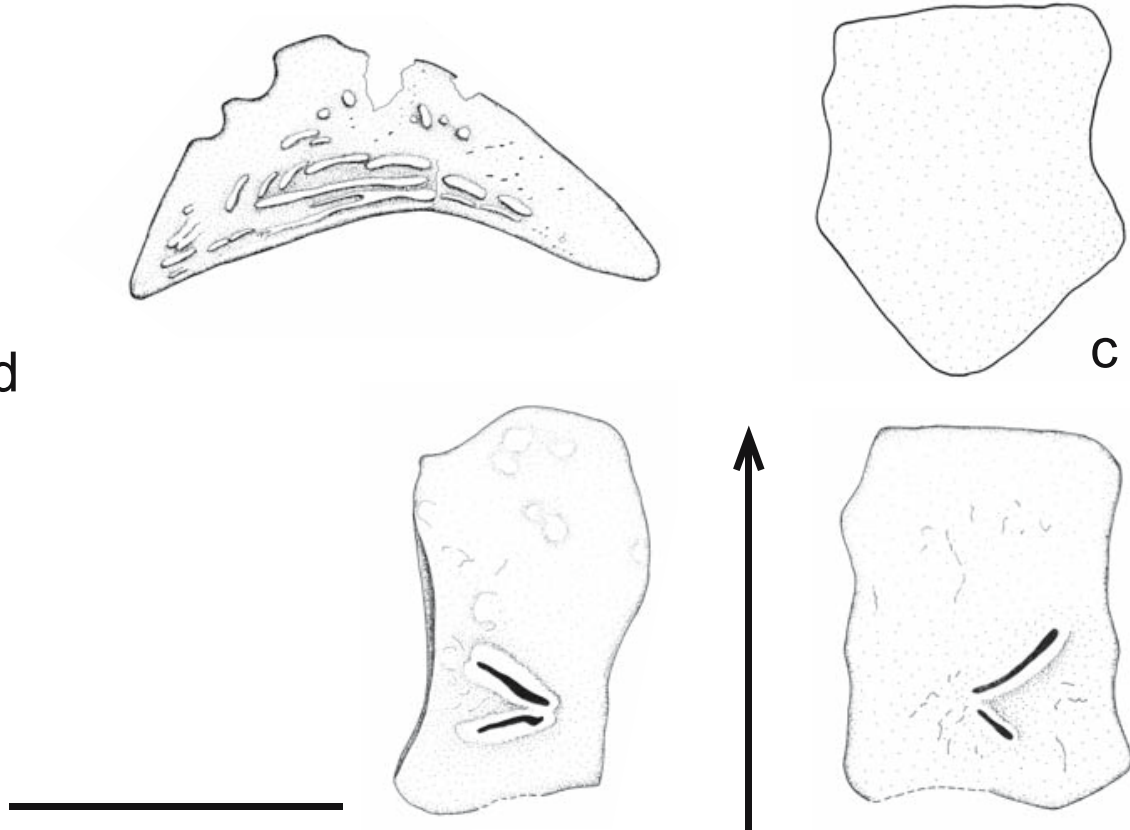

e
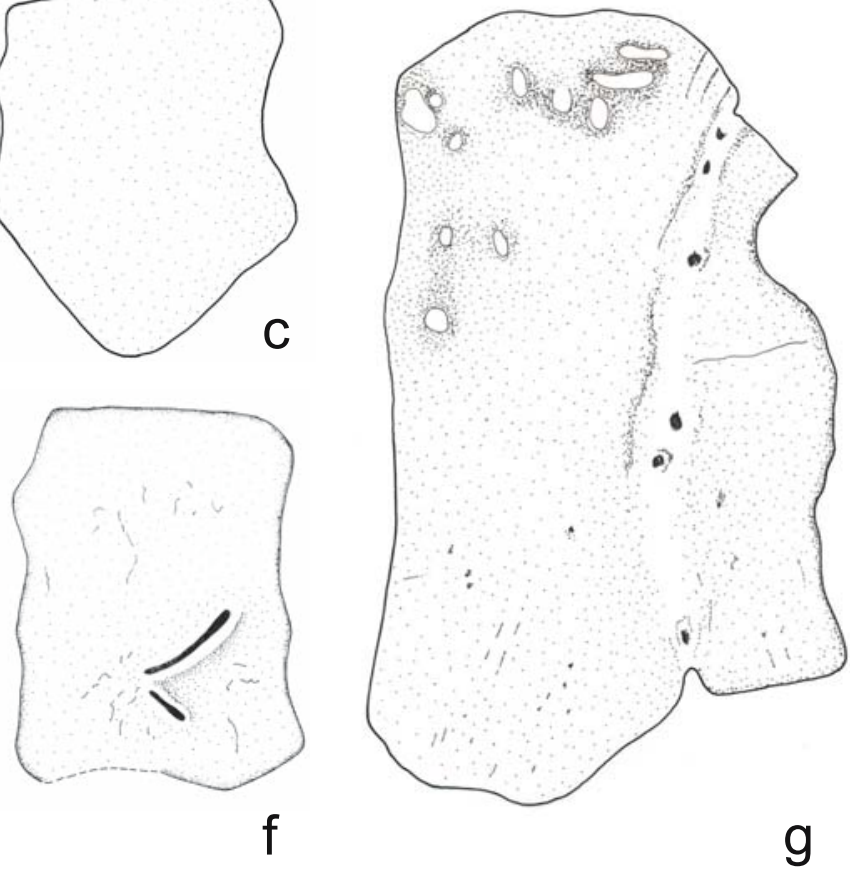

Text-fig. 26. Aeduella blainvillei (Agassiz, 1833). a, b - drawing and photograph (whitened) of the skull roof in dorsal view. MHK 82787. Scale bars $5 \mathrm{~mm}$. c, $d, \mathrm{e}, \mathrm{f}, \mathrm{g}$ - isolated bones of the rostral part and the skull roof. The arrow indicates the front for all bones. Scale bar represents $5 \mathrm{~mm}$ for all bones. $\mathrm{c}$ - rostro-postrostral. MHK 82788. $\mathrm{d}$ - right supraorbital anterior in lateral view. MHK 82782. e - left parietal in dorsal view with two pit lines. MHK 82804. $\mathrm{f}$ - right parietal in dorsal view with two pit lines. MHK 82785. g - right frontal in dorsal view with pores of the supraorbital sensory canal. MHK 82767. Abbreviations: Dsph dermosphenotic; Fr - frontal; ioc - infraorbital canal; Pa - parietal; pl - pit line; $\mathrm{Rpr}$ - rostropostrostral; soc - supraorbital canal; Sorb - supraorbital.

Cheek bones. The large orbit is surrounded by the anterior supraorbital anteriorly and by the dermosphenotic dorsally. In addition a small triangular shaped supraorbital forms part of the border of the orbit dorsally. This supraorbital bone is situated along the lateral margin of the dermosphenotic anterior to the ventrolateral process of the dermosphenotic (Text-figs 25, 26a, b). It is uncertain if this small bone is always present. Heyler (1969: figs 48, $49,54,55$ etc.) figured a triangular shaped supraorbital in some specimens of Aeduella blainvillei from Muse and in Bourbonnella guilloti, but this bone is missing in other specimens of Aeduella blainvillei and other members of the Aeduellidae.

The preoperculum is very small (D 04.11.95.19; MHK 82784). It is narrow ventrally, and broadens in a dorsoanterior direction. The bone is only slightly anteriorly inclined but does not divide into two branches (Text-fig. 25). This differs from the peropercular condition of Progyrolepis heyleri, Amblypteridae, and others. The preopercular sensory canal runs along the dorso-posterior margin of the preoperculum. There is a short branch off the preopercular canal that forms the horizontal pit line. The shape of the 

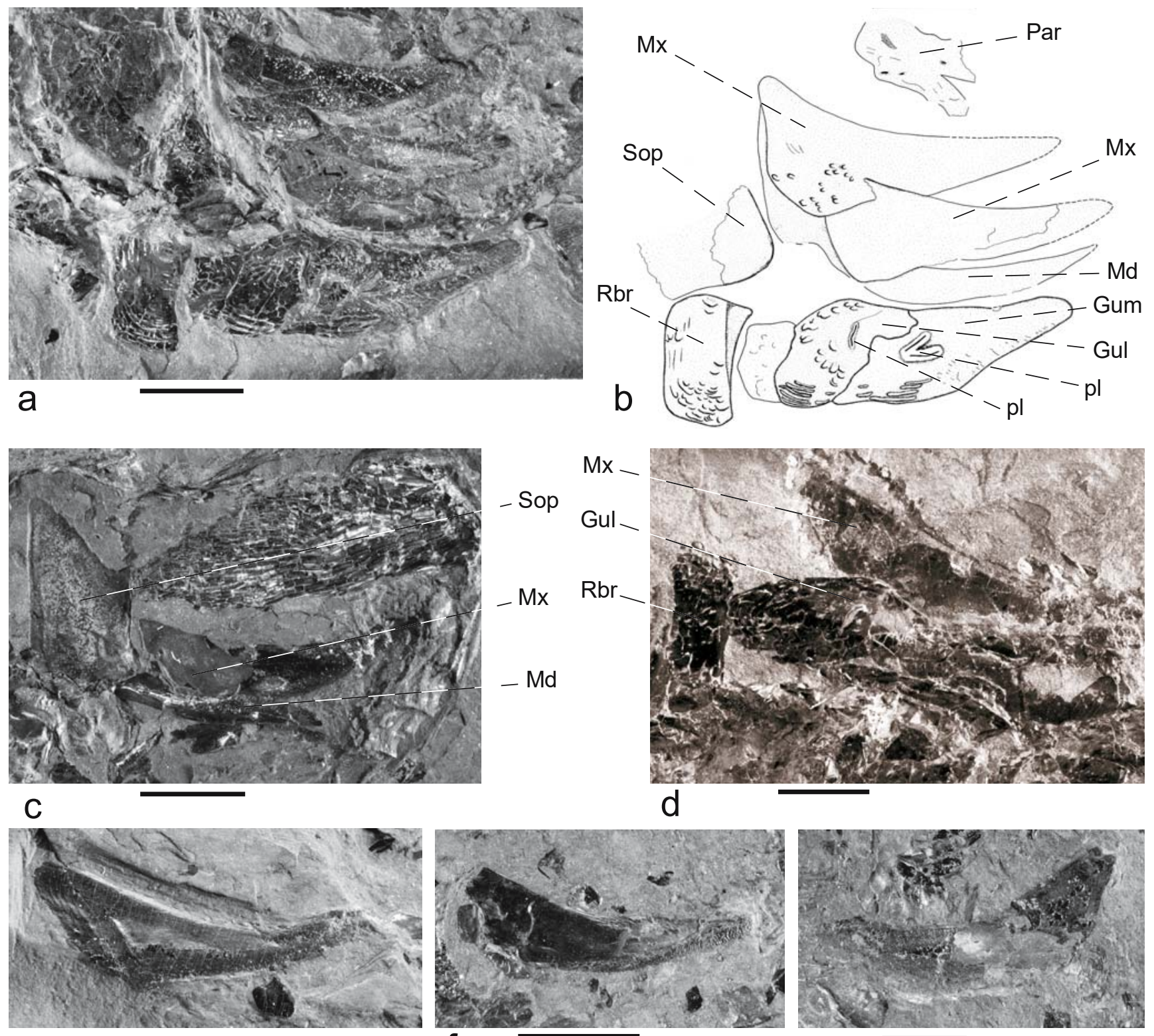

e
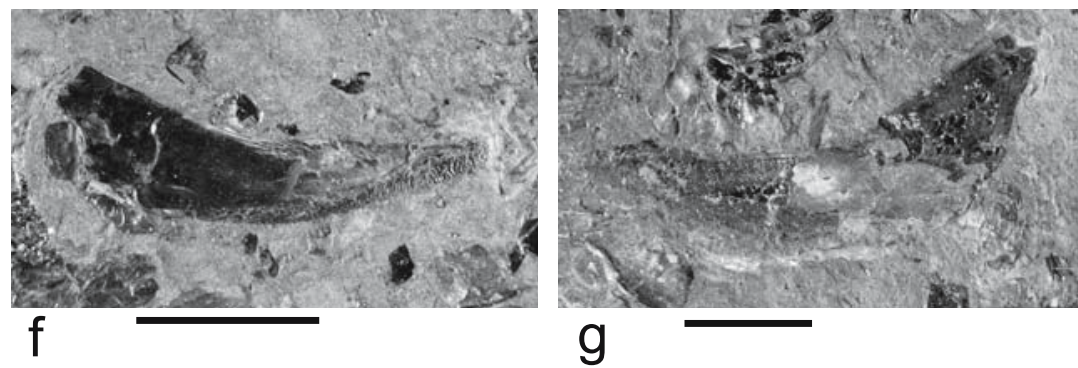

Text-fig. 27. Aeduella blainvillei (Agassiz, 1833). Scale bars $5 \mathrm{~mm}$. a, b-photograph and drawing of the gulars, branchiostegal ray, suboperculum and maxilla in lateroventral view. MHK 82807. $\mathrm{c}$ - right suboperculum and maxilla in lateral view. MHK 82797. d - lateral gular in ventral view, right maxilla and branchiostegal ray in lateral view. MHK 82784. e - right maxilla in lateral view. MHK 82792. f - right maxilla in lateral view. G 4/1. g - left maxilla in lateral view. G 5. Abbreviations: Gul - lateral gular; Gum - medial gular; Md - mandible; Mx - maxilla; pl - pit line on the lateral and medial gulars; Par - parasphenoid; Rbr branchiostegal ray; Sop - suboperculum.

preoperculum is the same as in Aeduella blainvillei from Muse. Small rounded postorbital bones located anterior to the preoperculum are partly preserved so it is not possible to state the number or illustrate their exact position.

Jaws. The maxilla is preserved in many specimens (BX 04.11.97.58; BX 07.09.97; BX 28.09.96; D 04.11.95.6; D 20.03.99.6; D 26.11.95.7; MHK 82770; MHK 82803 and others). The basic feature of the maxilla is the triangular shape of the posterior portion. The maxilla is pointed anteriorly, and it continuously broadens in a posterior direction so that the bone is deepest posteriorly. The ventral margin of the maxilla is slightly convex, and sometimes the maxilla is slightly bent anteriorly (Heyler 1969: fig. 126D). The majority of trianguloid maxillary plates extend in a dorsal or dorso-posterior direction to form a process (Text- figs $27 \mathrm{a}, \mathrm{b}, 28 \mathrm{a}-\mathrm{c})$. This process has been recorded in the majority of maxillaries, but is missing in some (Text-figs $27 \mathrm{c}-\mathrm{e}, \mathrm{g}, 28 \mathrm{~d}-\mathrm{f})$. This process was not recorded by Heyler (1969) in the specimens of Aeduella blainvillei from Muse, and Heyler $(1969,2000)$ considered this difference to be the character that defined a different taxon. Posteriorly, the maxilla is not very deep, and the ratio of the length of the maxilla to its depth is a factor of great variability that varies from 2.5 (MHK 82770; Text-fig. 28a, c) to 4 (D 04.11.95.6). The ratio is on average from 3 to 3.5 . I believe the presence or absence of the maxillary plate extension in a dorsal or dorso-posterior direction reflects the variability in range of Aeduella blainvillei. The ventral margin of the maxilla bears minute teeth attached to tubules (Text-fig. 29). One maxilla from an adult specimen (D 04.11.95.6) in medial view 


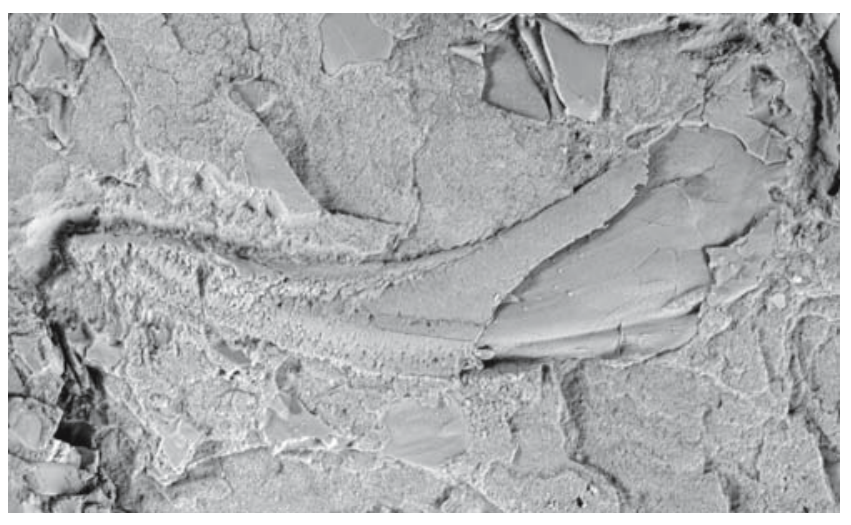

a

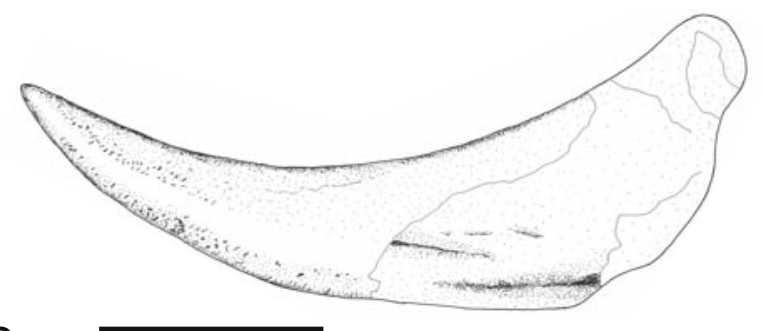

C

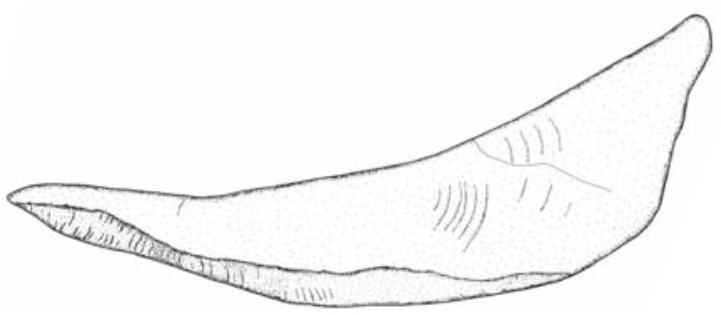

e

Text-fig. 28. Aeduella blainvillei (Agassiz, 1833). Maxilla. Scale bars $5 \mathrm{~mm}$. a - photograph (whitened) and c drawing of the left maxilla in lateral view. MHK 82770. b - posterior part of the right maxilla in lateral view. D 11.02.95, whitened. $d$ - right maxilla in lateral view. MHK 82792. e - left maxilla of juvenile specimen in lateral view. G 4/2. f - right maxilla of juvenile specimen in lateral view. BX 07.09.97.

exhibits a conspicuous horizontal lamina along the ventral border of the maxilla. The maxilla bears inconspicuous flat tubercles especially on the ventral half of the exposed surface of the bone.

The lower jaw is usually badly preserved (Text-fig. 27a, b). It is a weak bone (BX 04.11.97.58) that is slightly bent anteriorly. The pores of the mandibular sensory canal are arranged in a line in a postero-anterior direction (D 20.03.99).

Dentition. The dentition, consisting of tubular teeth, is an important feature of Aeduella blainvillei. The tooth consists of the tubule with a small tooth-cusp distally. The same teeth are on the upper and lower jaws, but especially well preserved are those on the maxilla. The whole tubule is laterally overlapped by the thin bone lamina of the maxilla, and only the small tooth-cusp protrudes above the jaw edge. This type of dentition was previously well described by Heyler (1969), but isolated maxillary bones from Buxièresles-Mines make it possible to compare teeth from different stages of ontogenetic development. Tubular teeth from a juvenile specimen consist of a short strong tube with a small tooth-cusp mounted distally. Text-fig. 29c, d shows a maxilla of length $12 \mathrm{~mm}$ which represents a juvenile

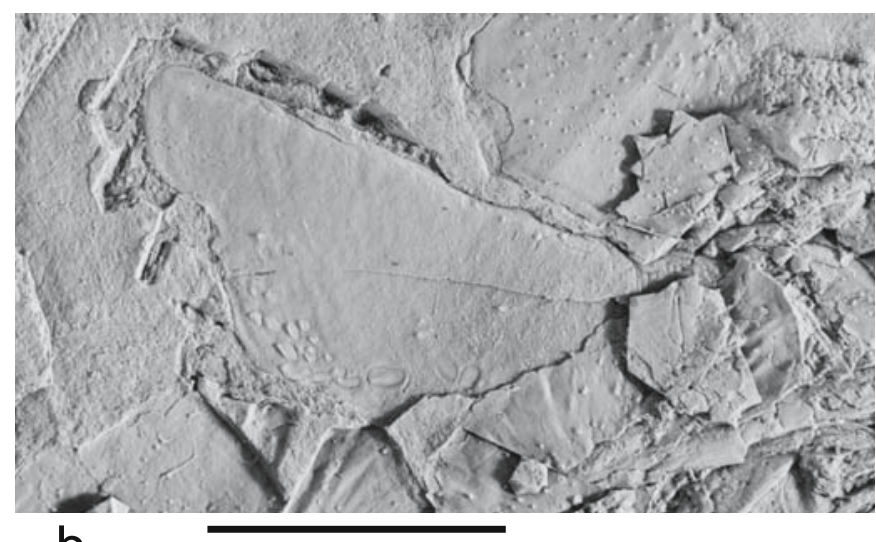

b

d
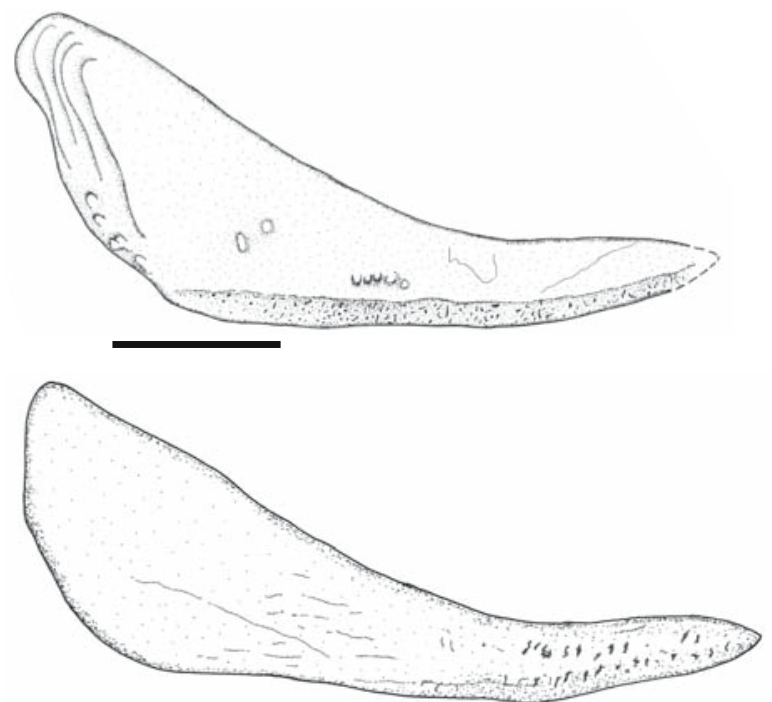


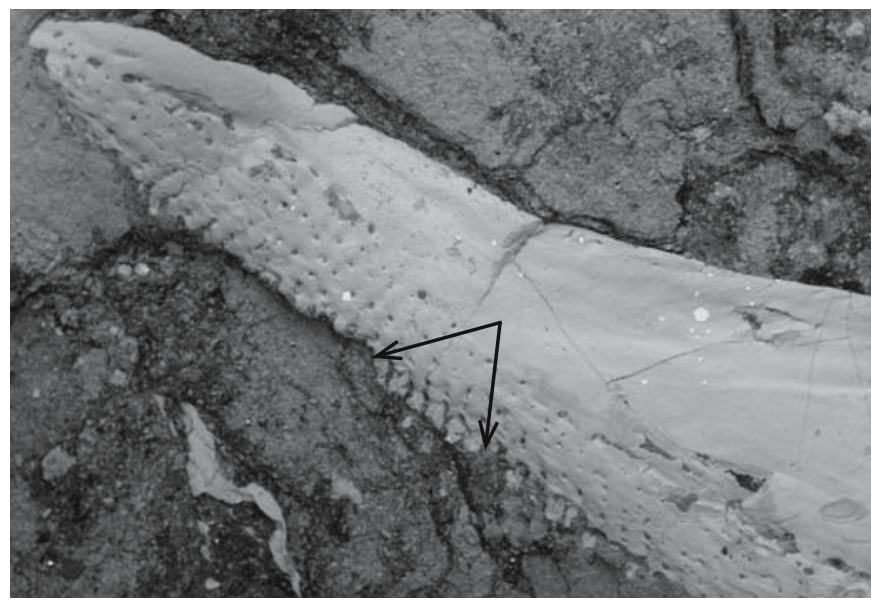

a

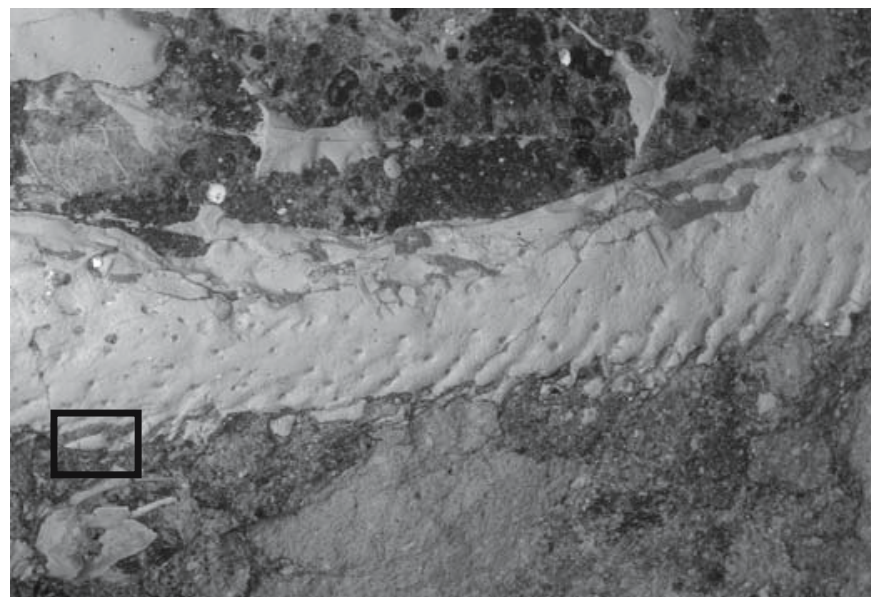

C

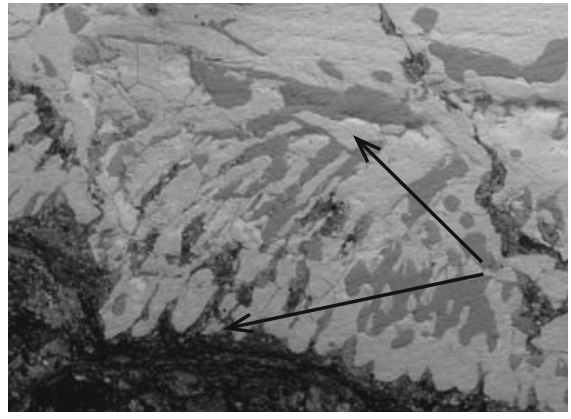

e

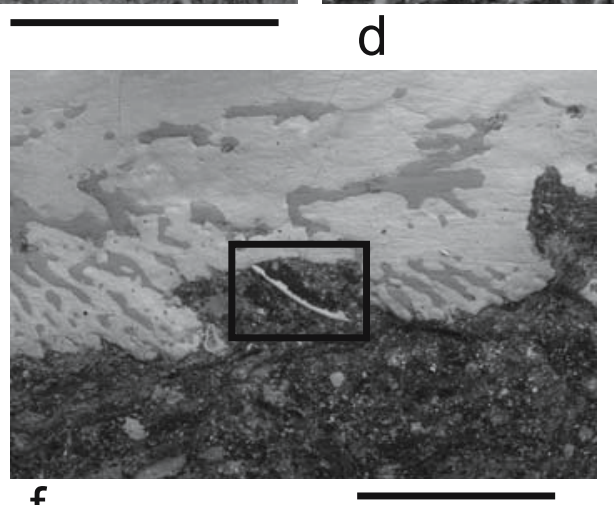

f

d

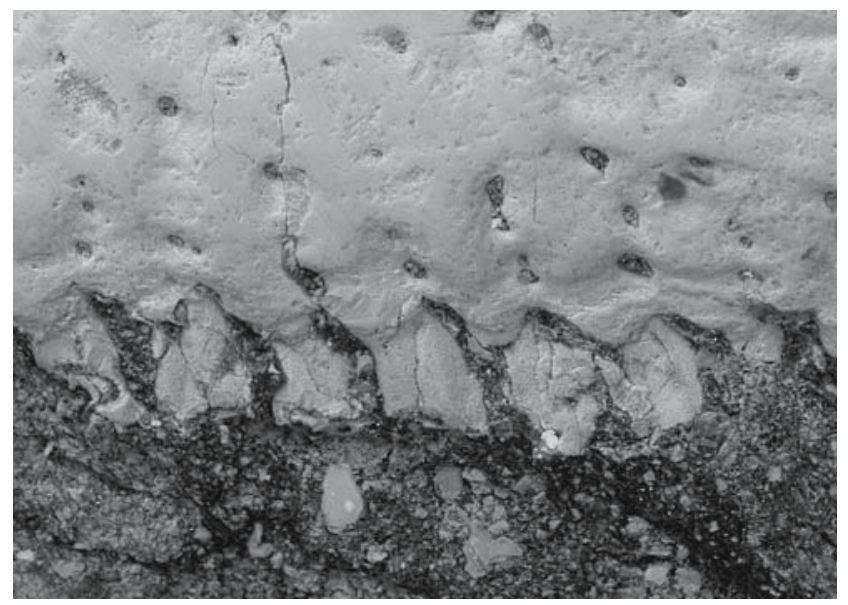

b
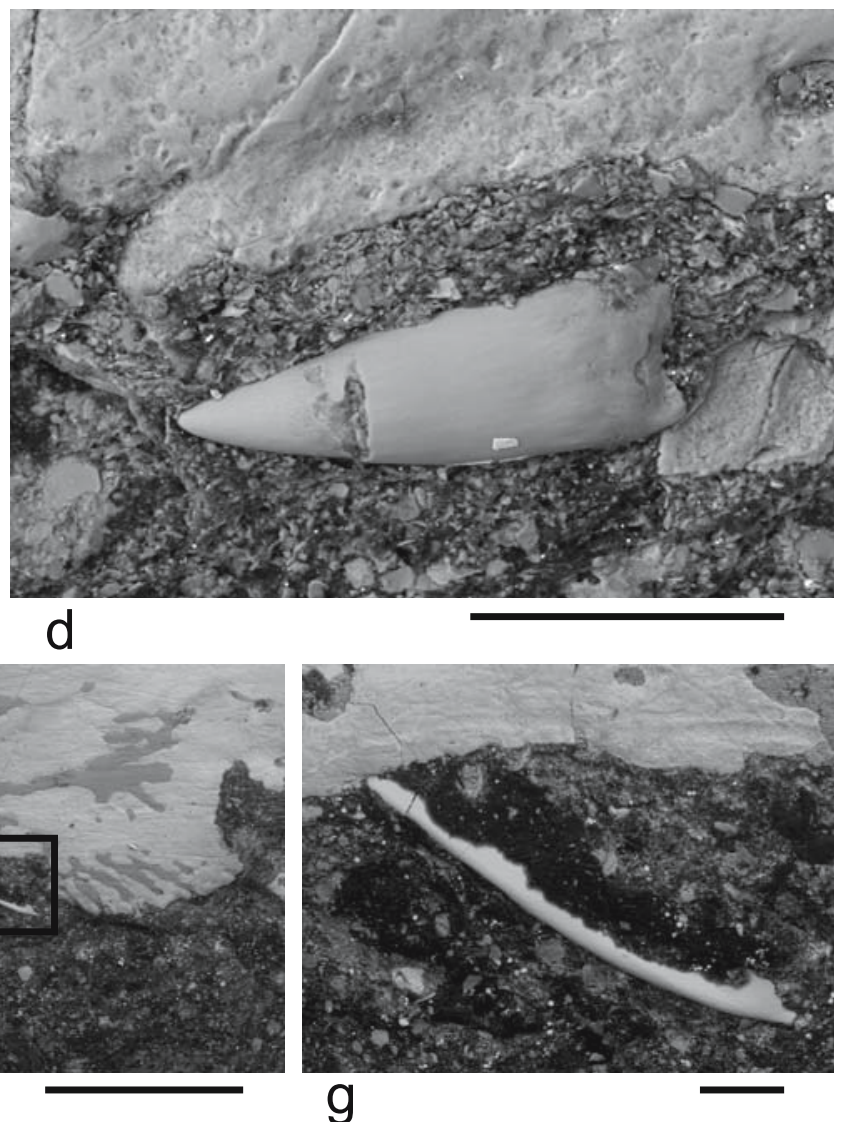

Text-fig. 29. Aeduella blainvillei (AgAssiz, 1833). a - anterior part of left maxilla of juvenile specimen in lateral view. The maxilla is $9 \mathrm{~mm}$ long. Arrows delimit the fragments of tubular teeth figured at b of this Text-fig. Specimen G 4/2. Scale bar $1 \mathrm{~mm}$. b - fragments of short strong tubules of tubular teeth. The teeth-cusps are broken. G 4/2. Scale bar $100 \mu \mathrm{m}$. $\mathrm{c}$ - anterior part of left maxilla of juvenile specimen. The maxilla is $12 \mathrm{~mm}$ long. Frame marks the view at $\mathrm{d}$ of this Text-fig. G 4/1. Scale bar $1 \mathrm{~mm}$. $d-$ isolated short tubular tooth of juvenile specimen. Tubule of the tooth is short and strong. It is terminated apically by the tooth-cusp. G 4/1. Scale bar $100 \mu \mathrm{m}$. e - anterior part of left maxilla of adult specimen in lateral view. The maxilla is $21 \mathrm{~mm}$ long. Tubular teeth with long tubules are covered from lateral side by maxillary bone and only short teeth-cusps project on the ventral edge of the maxillary. The arrows indicate the positioning of the tubular tooth on the maxillary. G 6. Scale bar $1 \mathrm{~mm}$. $\mathrm{f}$ - middle part of the ventral edge of the same maxilla as at a of this Text-fig. with isolated tubular tooth (marked by the frame) which is figured at higher magnification at g of this Text-fig. G 6. Scale bar $1 \mathrm{~mm}$. g - isolated tubular tooth of adult specimen partially overlapped by the sediment. The tooth consists of very long slender tubules which are terminated by small sharply pointed tooth-cusp. G 6. Scale bar $100 \mu \mathrm{m}$.

were also recorded in slightly deformed operculars (BX 01.08.97.1; MHK 82771; MHK 82773). The operculum is rounded and narrower dorsally, it has a straight border ventrally which usually forms an angle of $90^{\circ}$ with the anterior and posterior borders of the operculum. However, the ventral margin in some specimens is oblique and forms an acute angle with the anterior margin of the operculum. This character adds to the variability of the operculum. The operculum exhibits easily recognizable concentrically arranged incremental lines which are usually combined with 


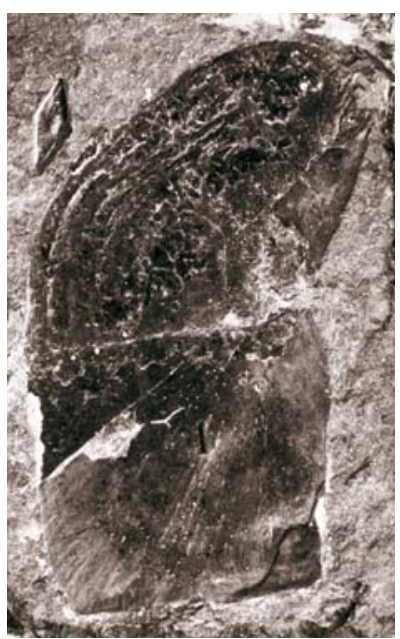

a

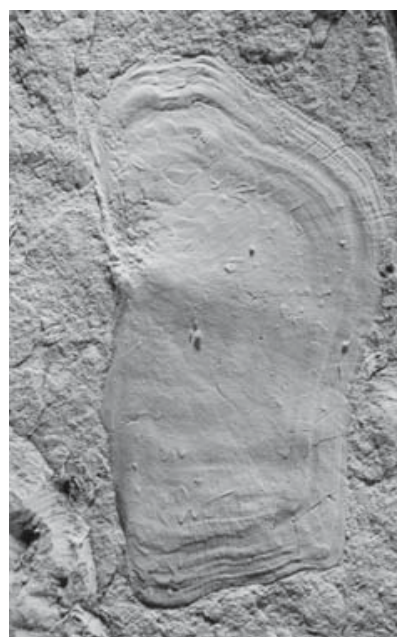

e

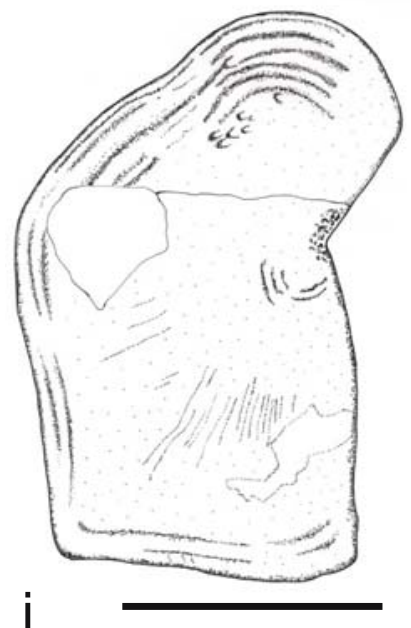

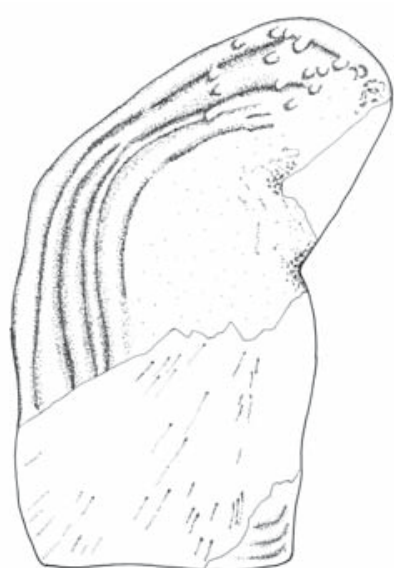

b

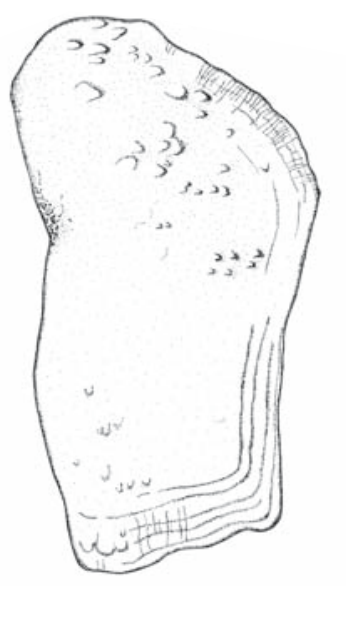

f

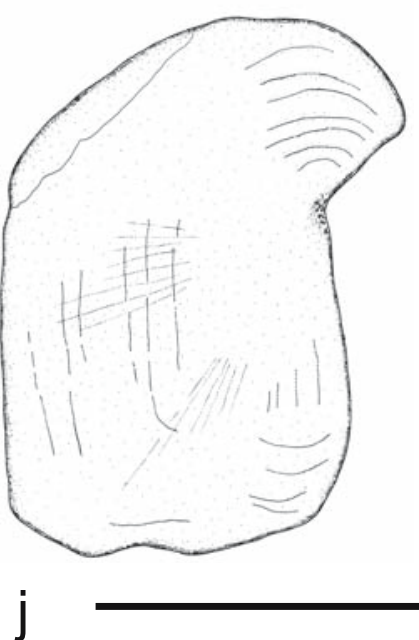

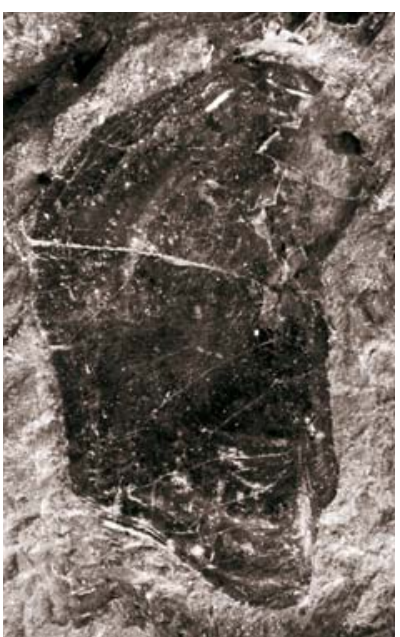

C

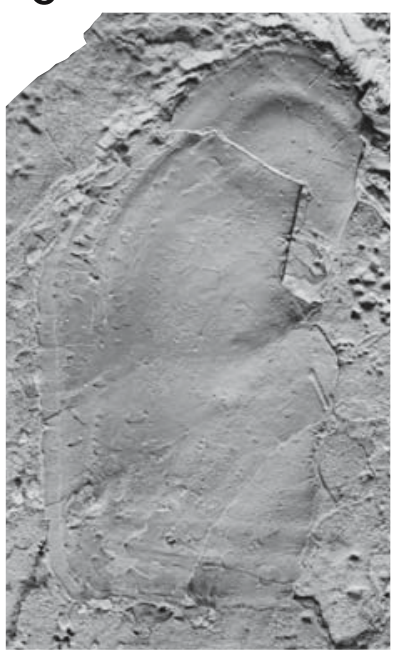

g

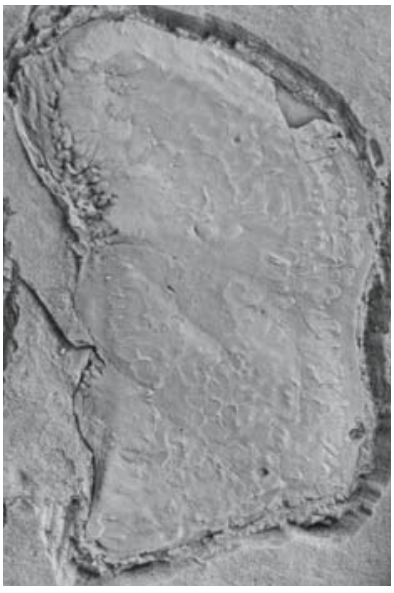

k
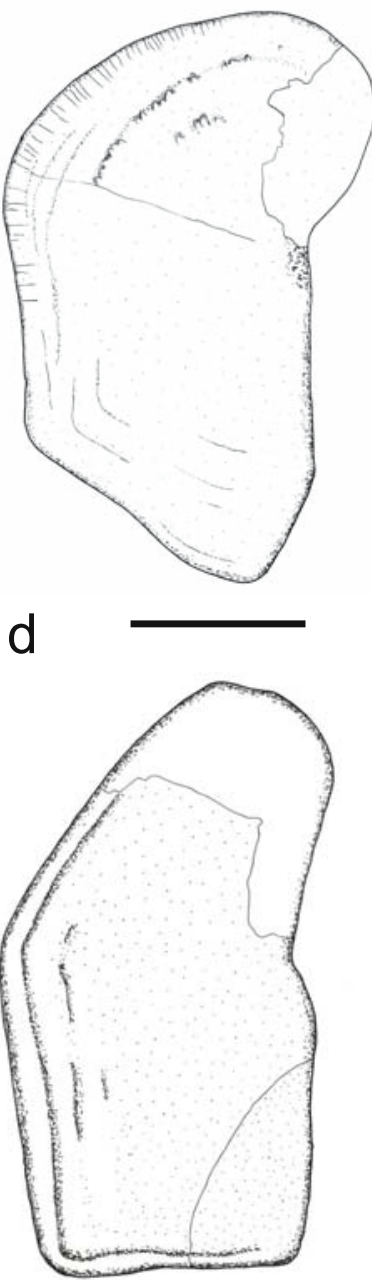

h

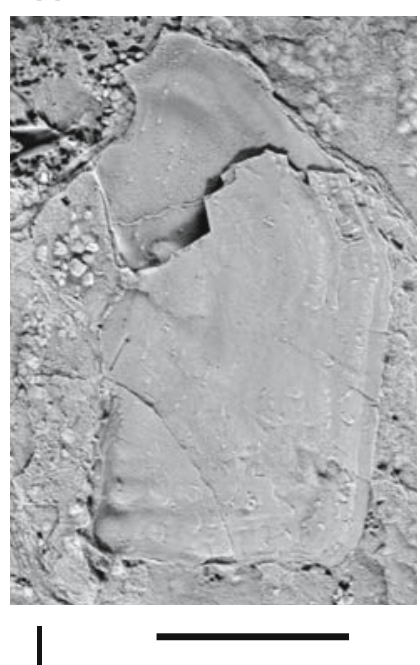

Text-fig. 30. Aeduella blainvillei (Agassiz, 1833). A set of opercular bones showing their variability in bending and an example of their ventral border. Scale bars $5 \mathrm{~mm}$. a - photograph and b - drawing of the right operculum in lateral view. MHK 82776. $c$ photograph and $d$ - drawing of the right operculum in lateral view. MHK 82791. $e$ - photograph (whitened) and $f$ - drawing of the left operculum in lateral view. BX 01.08.97.1. $\mathrm{g}$ - photograph (whitened) and $\mathbf{h}$ - drawing of the right operculum in lateral view. MHK 82771. $\mathrm{i}$ - right operculum in lateral view. MHK 82771. j - right operculum in lateral view. BXM 080. $\mathrm{k}$ - left operculum in lateral view. D 04.10.98, whitened. I - left operculum in lateral view. MHK 82768, whitened.

fine lines forked radially from the ossification centre which is situated anteriorly in the area where the operculum bends (Text-figs 30, 31a, b, 32f, g). Incremental lines and radially arranged lines are most well developed in young specimens.
The exposed surface of the operculum bears flat tubercles orientated in a posterior direction. The opercular bones from Buxières-les-Mines are very similar in shape to those of Neslovicella elongata (Štamberg 2010b: fig. 6) but are 


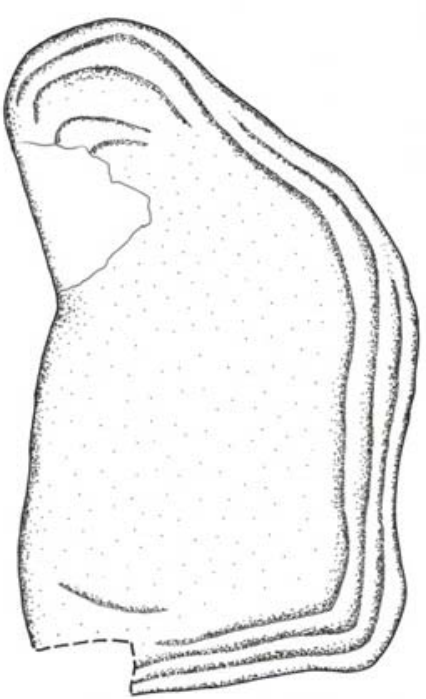

a

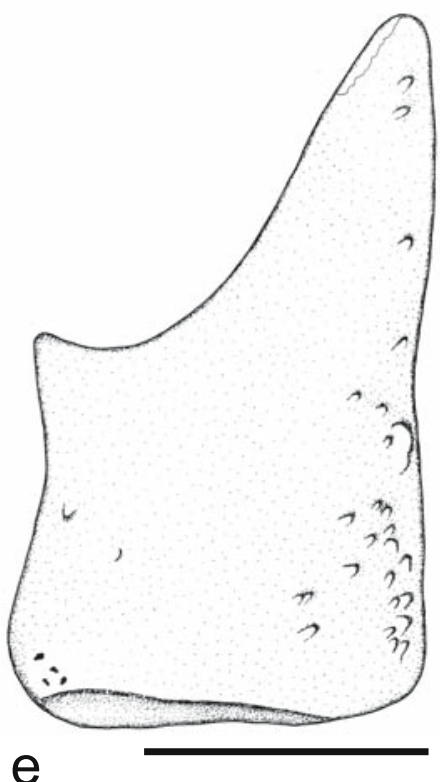

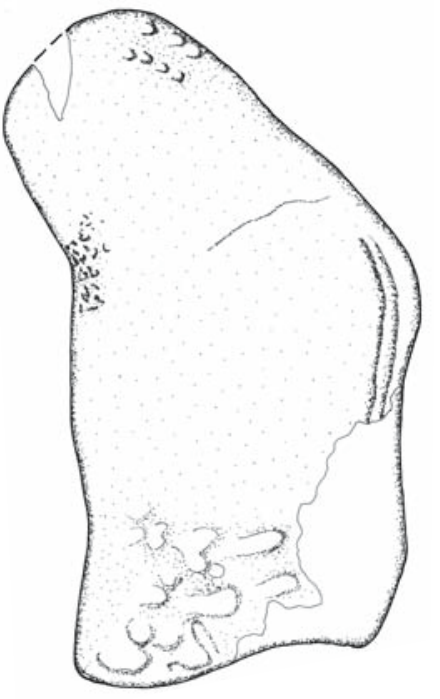

b

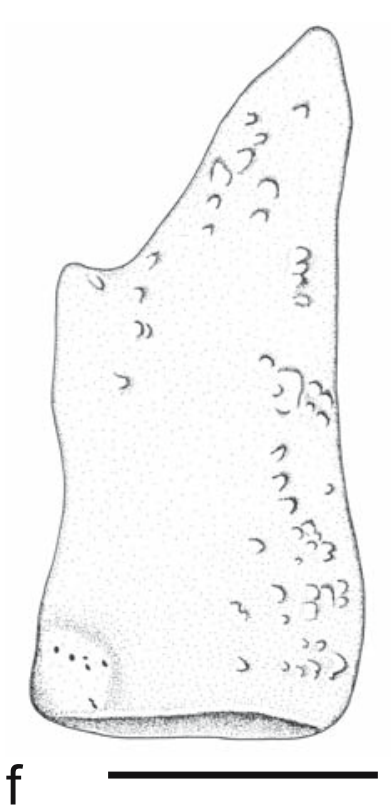

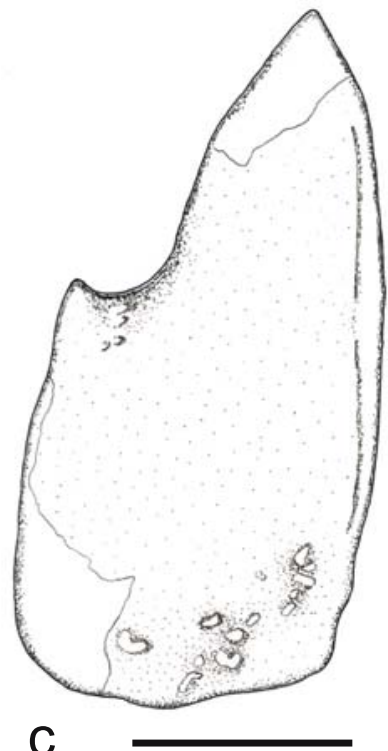

C

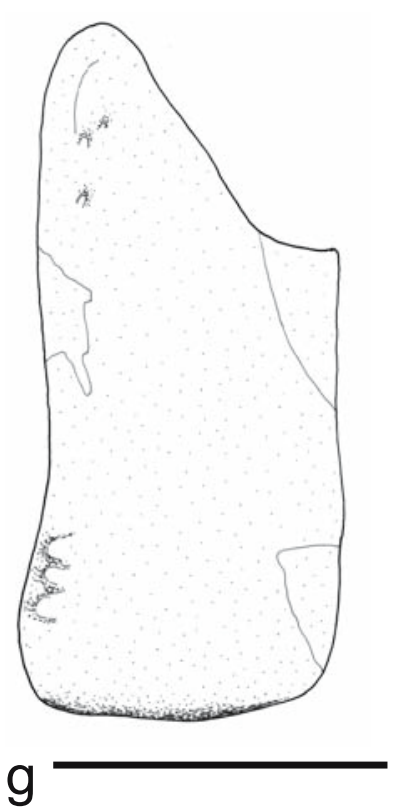

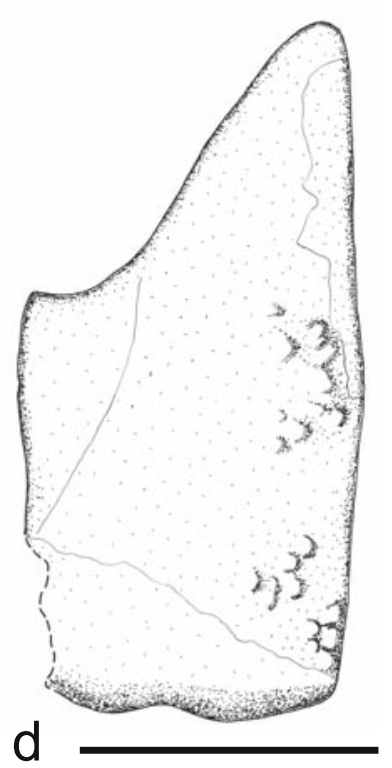

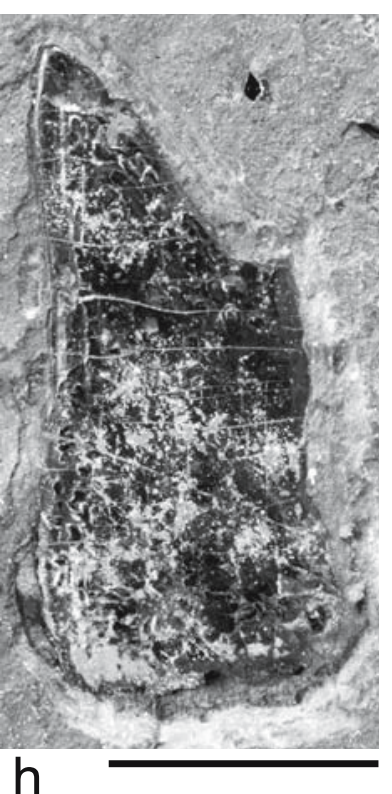

Text-fig. 31. Aeduella blainvillei (AgAssiz, 1833). A set of opercular and subopercular bones showing their variability. Scale bars 5 mm. a - left operculum in lateral view. MHK 82773. b - left operculum in lateral view. MHK 82775. c - left suboperculum in lateral view. MHK 82769. $d$ - left suboperculum in lateral view. MHK 82786. $\mathrm{e}$ - left suboperculum in lateral view. G $3 / 1$. f - left suboperculum in lateral view. G 3/1. g - right suboperculum in lateral view. BX 07.09.97. $\mathrm{h}$ - right suboperculum in lateral view. G 3/2.

slightly different from these bones in Aeduella blainvillei from Muse. Heyler (1969) figured two types of Aeduella blainvillei opercula from Muse. One type is characterized by its regularly round posterior shape (Heyler 1969: figs 58, $77 \mathrm{C}, \mathrm{E}$ ), the second type is distinguished by its irregularly bent posterior border which forms a hump (Heyler 1969: figs $45,53,79)$. Specimens from Buxières-les-Mines exhibit opercular bones with a hump, and moreover narrow in a dorsal direction. Their clearly visible bend in the upper third of the bone is always present. The opercular bones from Buxières-les-Mines are also slightly deeper than their length compared to these bones in Aeduella blainvillei from Muse. The ratio of the depth of the operculum to its length in Aeduella blainvillei from Muse is 1.35-1.72 but in the same bones from Buxières-les-Mines the ratio is 1.75-2.15. Heyler $(1969,2000)$ previously pointed out the differences between these bones from Muse and Buxières-les-Mines, and he argued that this ratio taken together with some differences in the shape of the maxilla, should lead to the specimens from Buxières-les-Mines being assigned to a new species of Aeduellidae. The dermal bones of the operculogular series document large variability within these bones, and I am convinced that the observed differences in shape of the operculum are a demonstration of the variability within these bones in the range of species of Aeduella blainvillei rather than a defining character of a new taxon.

The suboperculum (Text-figs 31c- $\mathrm{h}, 32 \mathrm{f}, \mathrm{g}$ ) is trapezoidal in shape and is conspicuous elongated in a dorsoventral direction (BX 07.09.97; D 30.08.98; D 4.11.95(19); MHK 82769; MHK 82786). The suboperculum is unusually deep, and its ventral margin reaches to the level of the ventral margin of the maxilla. The dorsal border of the suboperculum slopes 


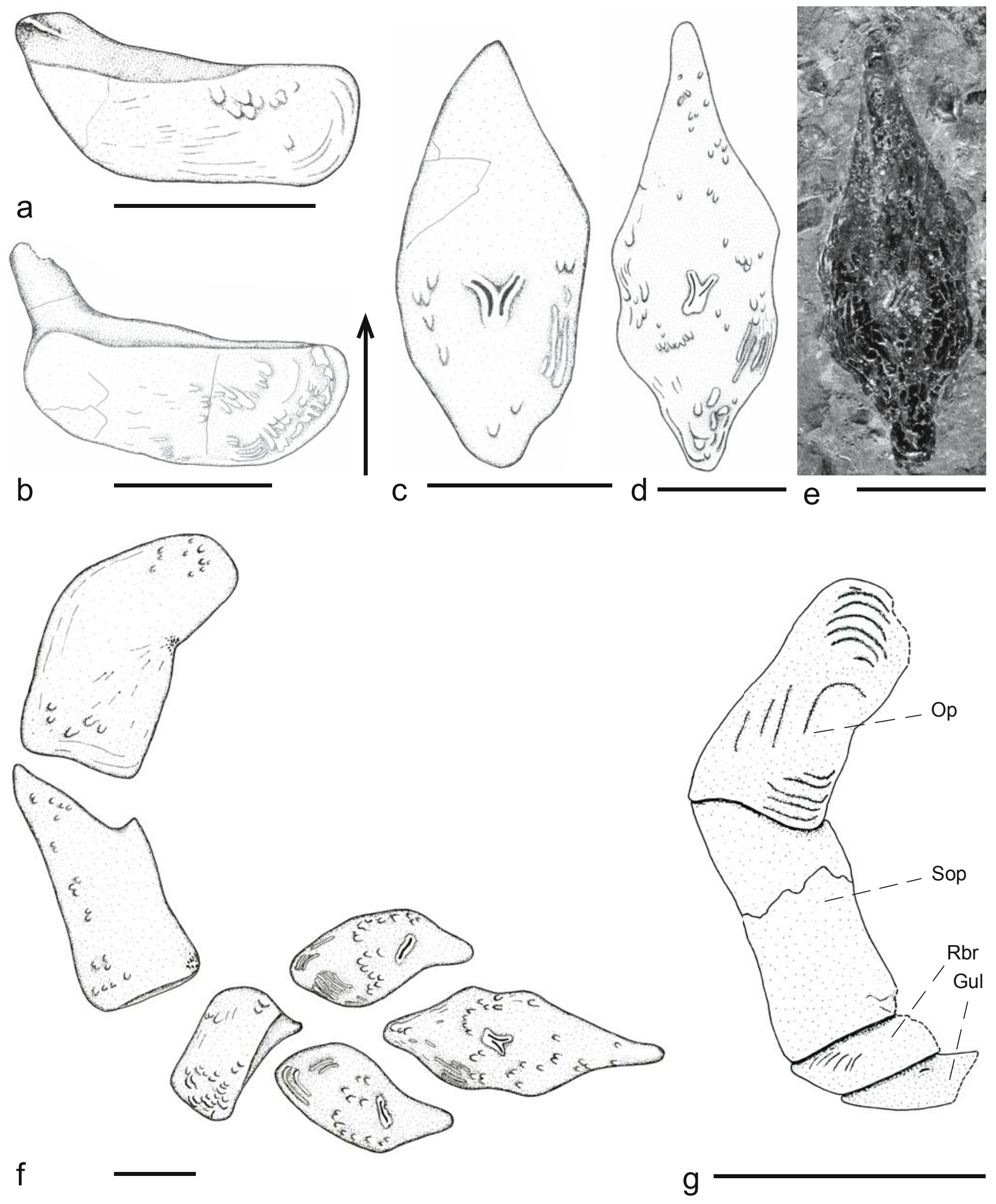

Text-fig. 32. Aeduella blainvillei (Agassiz, 1833). Scale bars $5 \mathrm{~mm}$. a - right branchiostegal ray in lateral view. BX 07.09.97. b right branchiostegal ray in lateral view. D 20.03.99.6. $\mathrm{c}$ - medial gular with pit lines in the form of a V. BX 07.09.97. d - drawing. e - photograph of medial gular. G 2. The arrow indicates the front of the bones on the figures a, b, $c, d$, e. $f$ - restoration of the mutual position of the operculum, suboperculum and branchiostegal ray in lateral view and lateral gular and medial gular in ventral view. g - operculo-gular series of juvenile specimen in lateral view. D 0411.95.19. Abbreviations: Gul - lateral gular; Op operculum; Rbr - branchiostegal ray; Sop - suboperculum.

significantly anteriorly, and therefore the posterior margin of the suboperculum is $1.3-1.9$ times deeper than the anterior margin. The depth of the suboperculum in its posterior region is twice its length. The shape of both the suboperculum and the operculum exhibit great variability which is most striking when considering the depth of the anterior margin of the 
suboperculum. The ratio of the depth of the anterior margin of the suboperculum to the suboperculum length fluctuates between 0.55 and 0.71 (Text-fig. 31e, f). The exposed surface of the suboperculum is ornamented with backward pointing flat tubercles. Some of the bones exhibit a narrow fold medially, directed along the bone's ventral margin without any sculpture (Text-figs 31e, f, 32f). This narrow strip of the suboperculum ventral margin was overlapped by the dorsal margin of the branchiostegal ray. The suboperculum is ventroanteriorly thickened with a scraped surface which serves for attachment of the muscles. The ventroanterior corner is the ossification centre of the suboperculum. The conspicuously sloping and concave dorsal margin of the suboperculum is one of the distinguishing characteristics of Aeduella blainvillei. An anteriorly sloping dorsal margin can also be observed in Spinarichthys dispersus, Neslovicella rzehaki or Neslovicella elongata (Štamberg 1988, 2007, 2010b), but not to such an extent as in Aeduella blainvillei. The suboperculum dorsal margin in Bourbonnella (Heyler 1969, Poplin 2001, Štamberg 2007, Mickle 2011), Decazella (Heyler 1969) or Puertollanichthys (Forey and Young 1985) is straight or only slightly concave.

Branchiostegal ray. Only one branchiostegal ray is present ventrally to the suboperculum (D 04.11.95.19; D 20.03.99.6; MHK 82782; MHK 82791; MHK 82794). Larger numbers of branchiostegal rays are not present due to the lack of space caused by the extreme depth of the suboperculum which reaches ventrally to the level of the maxilla ventral margin (Text-figs 27a, b, c, 32a, b, f, g). The presence of only one branchiostegal ray in Aeduella blainvillei is also a diagnostic feature of this species. The branchiostegal ray is rectangular in shape and bears a large hyoid process that projects anteriorly (Text-figs 27a, b, $32 \mathrm{a}, \mathrm{b}, \mathrm{f})$. The exposed surface of the branchiostegal ray is decorated with flat bumps pointing backwards. The hyoid process and narrow strip along the anterior margin of the bone is without sculpture, and was covered by the lateral gular. The hyoid process, devoid of sculpture, is unusually well developed with a variable large projection which points forwards under the medial margin of the lateral gular (Text-fig. 32f). The pronounced anterior projection on branchiostegal rays is described as the hyoid process by Pearson and Westoll (1979) in Cheirolepis and similarly by Gardiner (1984) in Mimipiscis toombsi. The branchiostegal ray projection in Mimipiscis toombsi or Cheirolepis is only a small extension of the ray anteriorly, but in Aeduella blainvillei this projection is very pronounced. Moreover, overlapping of the ventral margin of the suboperculum by the dorsal margin of the branchiostegal ray was documented, and conversely the anterior margin of the branchiostegal ray without sculpture is overlapped by the lateral gular. This arrangement of the branchiostegal ray and suboperculum is unusual in the Permo-Carboniferous actinopterygians and usually the suboperculum and following branchiostegal rays overlap in an anterior direction (Text-fig. 32f). Similar variance in the direction of overlap of the branchiostegal rays was described by Selezneva (1985) in Evenkia eunotoptera BERG, 1941.

Gular lateral and gular medial. Paired lateral gulars and one medial gular fill the space between the right and left lower jaws. The lateral gular (D 09.11.96.9; MHK 82782;
MHK 82791; MHK 82804; MHK 82807) is rhombic in shape, elongated in an anteroposterior direction, and is twice as wide as it is long (Text-figs 27a, b, d, 32f). The lateral gulars are overlapped by the medial gular anteromedially, but the right and left lateral gulars do not overlap each other medially. The lateral gular overlaps the branchiostegal ray posteriorly. The exposed ventral surface of the bone is ornamented with flat tubercles and ridges similarly as in other bones of the operculo-gular series. A pronounced pit line lies mid length on the lateral gular and a little nearer to the lateral side of the bone. The rhombic medial gular (D 20.03.99.6; D 09.11.96.9; BX 04.11.97.58; MHK 82788; MHK 82787; MHK 82800; MHK 82807) is conspicuously elongated in an anteroposterior direction. The bone is more than twice as long as it is wide, and significantly more slender anteriorly. The exposed ventral surface of the bone bears a few flat tubercles or short ridges. A prominent pit line forms slots in the form of a V in the centre of the bone. The region of the bone anterior to the pit lines is always longer than the posterior region in the medial gular. The shape of the medial gular and particularly its slender anterior region are characteristic for Aeduella blainvillei.

Dermal bones of the shoulder girdle. The posttemporal, supracleithrum, cleithrum and clavicle form the shoulder girdle dermal bone series.

The posttemporal of oval shape is only partly preserved (MHK 82796; MHK 82808), but the fragments suggest a large bone as was figured by Heyler (1969: figs 91, 92, 96B).

The supracleithrum is a narrow bone and in a dorsoventral direction markedly extended, tapering ventrally (Text-fig. 33d-f). The bone length is always less than one third the depth of the bone. A prominent projection developed dorsally joins the supracleithrum to the posttemporal. The lateral margin of the posttemporal overlaps the dorsal margin of the supracleithrum including its dorsal projection. The anterior margin of the bone which is overlapped by the operculum is markedly concave. The supracleithrum is rounded ventrally, and does not reach the ventral margin of the operculum. The lateral surface of the supracleithrum bears ridges which are arranged predominantly in a dorsoventral direction. The lateral sensory canal starts anteriorly to the dorsal process, passes diagonally through the dorsal third of the bone towards the posterior margin, and traverses to the scale as the main lateral sensory line. In medial view, the supracleithrum is reinforced in the area around the lateral sensory canal by two crests (Text-fig. 33e, f). The anterior margin of the supracleithrum is strengthened by the anterior crest (crista anterior) and the posterior crest (crista posterior) passes across the dorsal half of the bone. Both crests begin at the vaulted sensory canal (Text-fig. 33e, f). The strengthening of the medial side of the supracleithrum is very similar to that described by Štamberg (2007: fig. 21) in Neslovicella rzehaki.

The cleithrum (Text-fig. 33a-c) is very frequently preserved as an isolated bone or as part of a skull (BX 12, MHK 82768; MHK 82782). The bone consists of two branches, namely the lateral branch and ventral branch. The lateral branch is enlarged in an anteroposterior direction and elongated in a dorsoventral direction. It has an elliptical shape in lateral view, and dorsally tapers into a long process that reaches one third of the height of the operculum. Its 


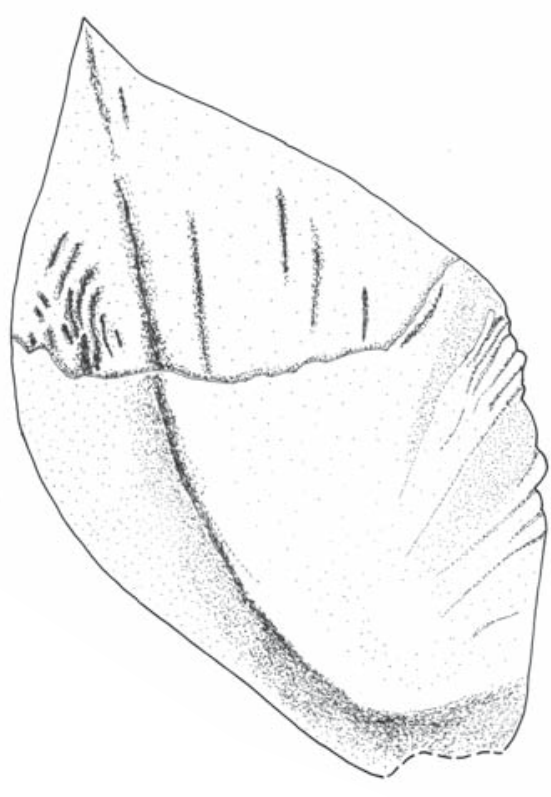

a

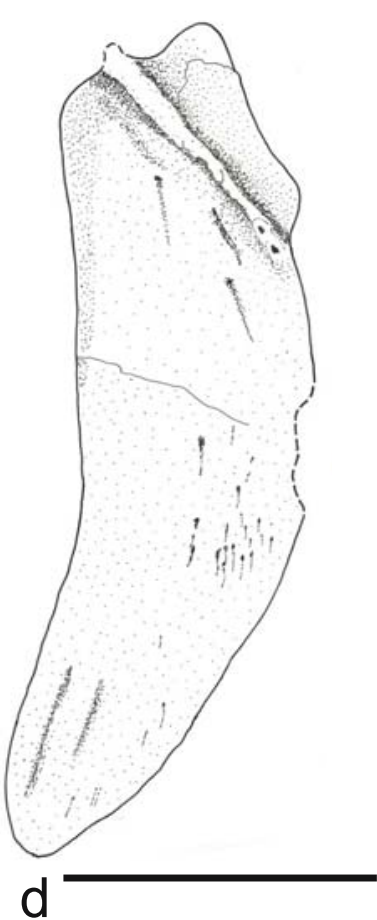

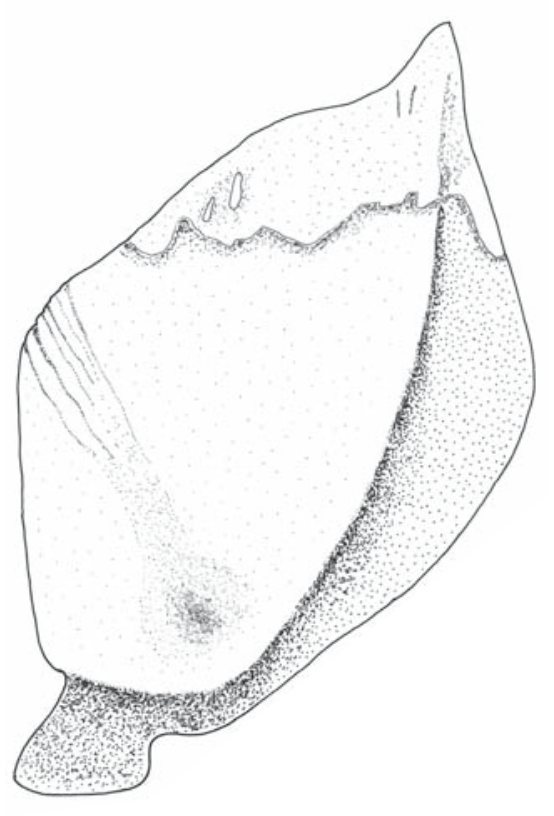

b

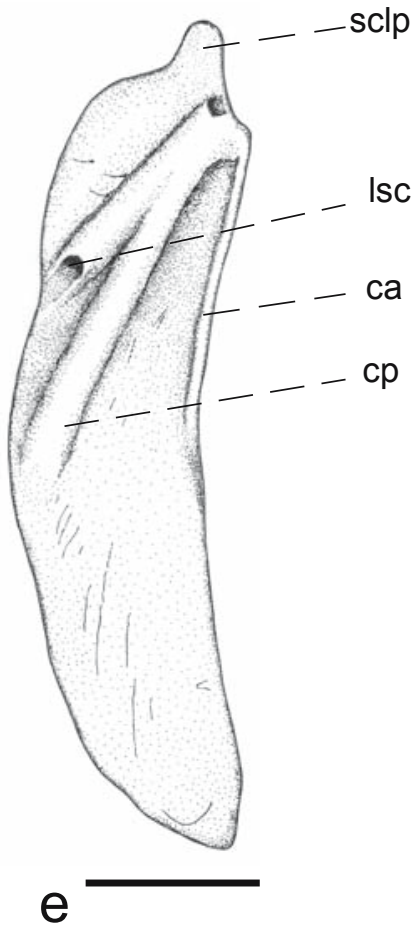

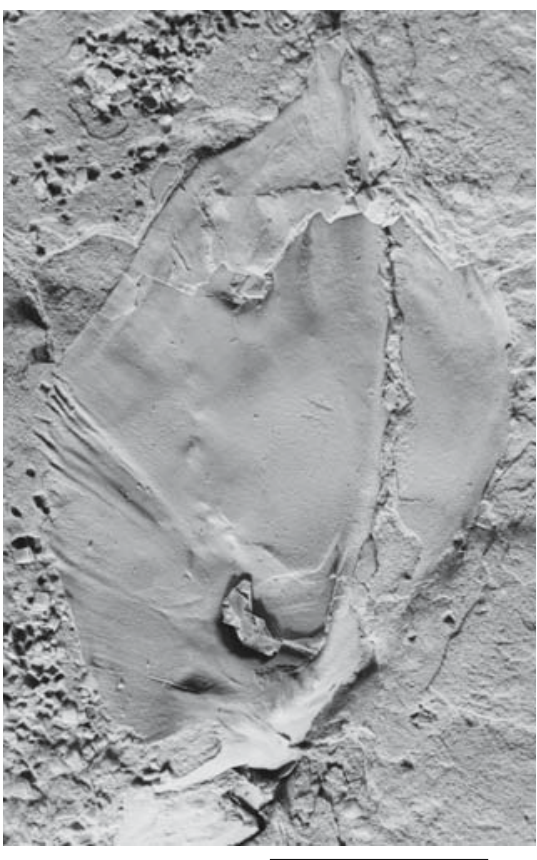

C

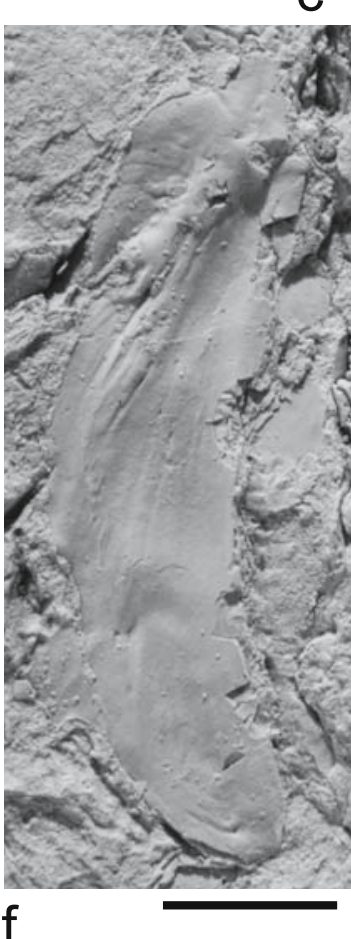

f

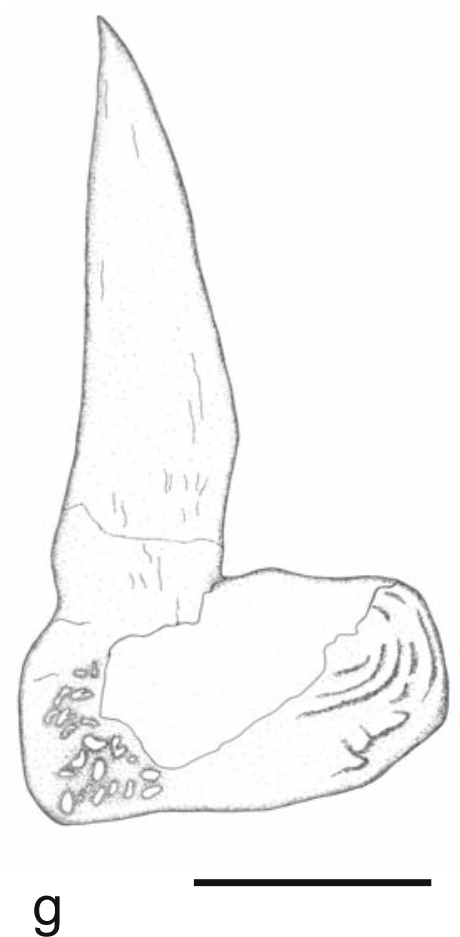

Text-fig. 33. Aeduella blainvillei (Agassiz, 1833). Dermal bones of the shoulder girdle. Scale bars 5 mm. a - right cleithrum in lateral view. MHK 82768. $b$ - drawing and $c$ - photograph (whitened) of right cleithrum in medial view. MHK 82771. d - right supracleithrum in medial view. MHK 82770. $\mathrm{e}$ - drawing and $\mathrm{f}$ - photograph (whitened) of left supracleithrum in medial view. G 1. g - right clavicle in lateral view. MHK 82784. Abbreviation: ca - crista anterior; cp - crista posterior; lsc - lateral sensory canal; sclp - process of supracleithrum.

anterior margin is conspicuously concave and forms the posterior boundary of the branchial cavity. The exposed lateral surface is ornamented with stout ridges apart from the area which is anteriorly overlapped by the operculum and suboperculum. The cleithrum is ventrally curved in a medial direction and forms the ventral branch which anteriorly borders with the clavicle. A cleithrum with much enlarged lateral branch is typical for Aeduella blainvillei, and the same form was described by Štamberg $(2007,2010 b)$ in Neslovicella rzehaki and Neslovicella elongata.
The clavicle is preserved as an isolated bone on specimen MHK 82789 (Text-fig. 33g). The bone consists of a short and relatively wide horizontal branch and very deep narrow dorsal branch. The exposed area of the horizontal branch of the clavicle is ornamented.

Body. Adult specimens reach $16 \mathrm{~cm}$ of the total body length (Text-fig. 35d). The trunk is anteriorly arched. The total body length is estimated to be 3.2 times the deepest part of the body and 5.1 times the length of the skull (MHK 82806; MHK 82809). In younger specimens such 


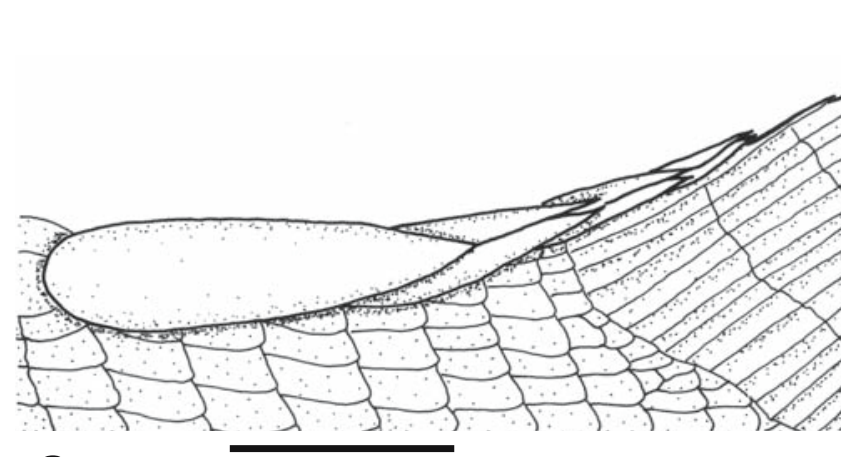

a
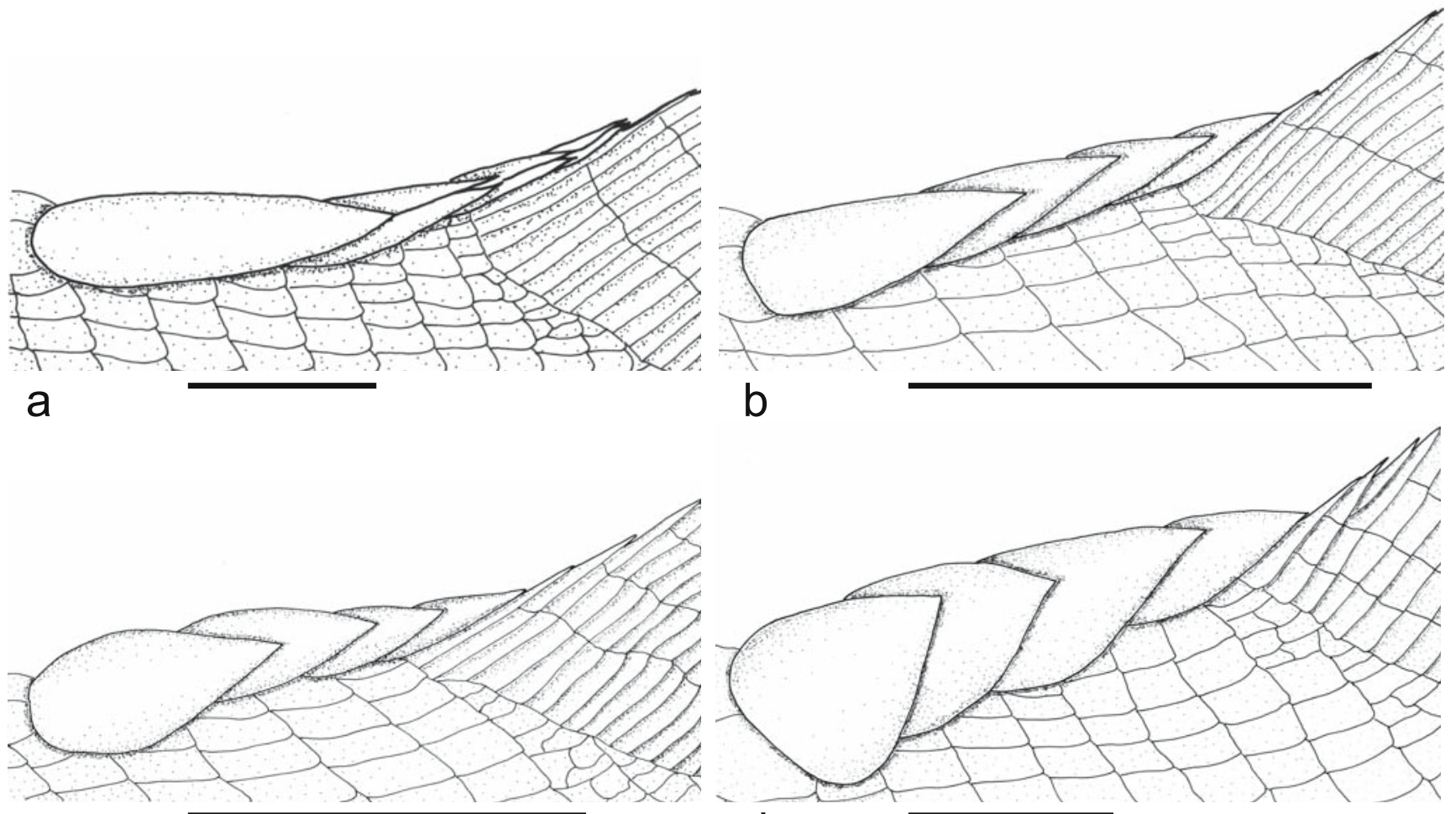

C
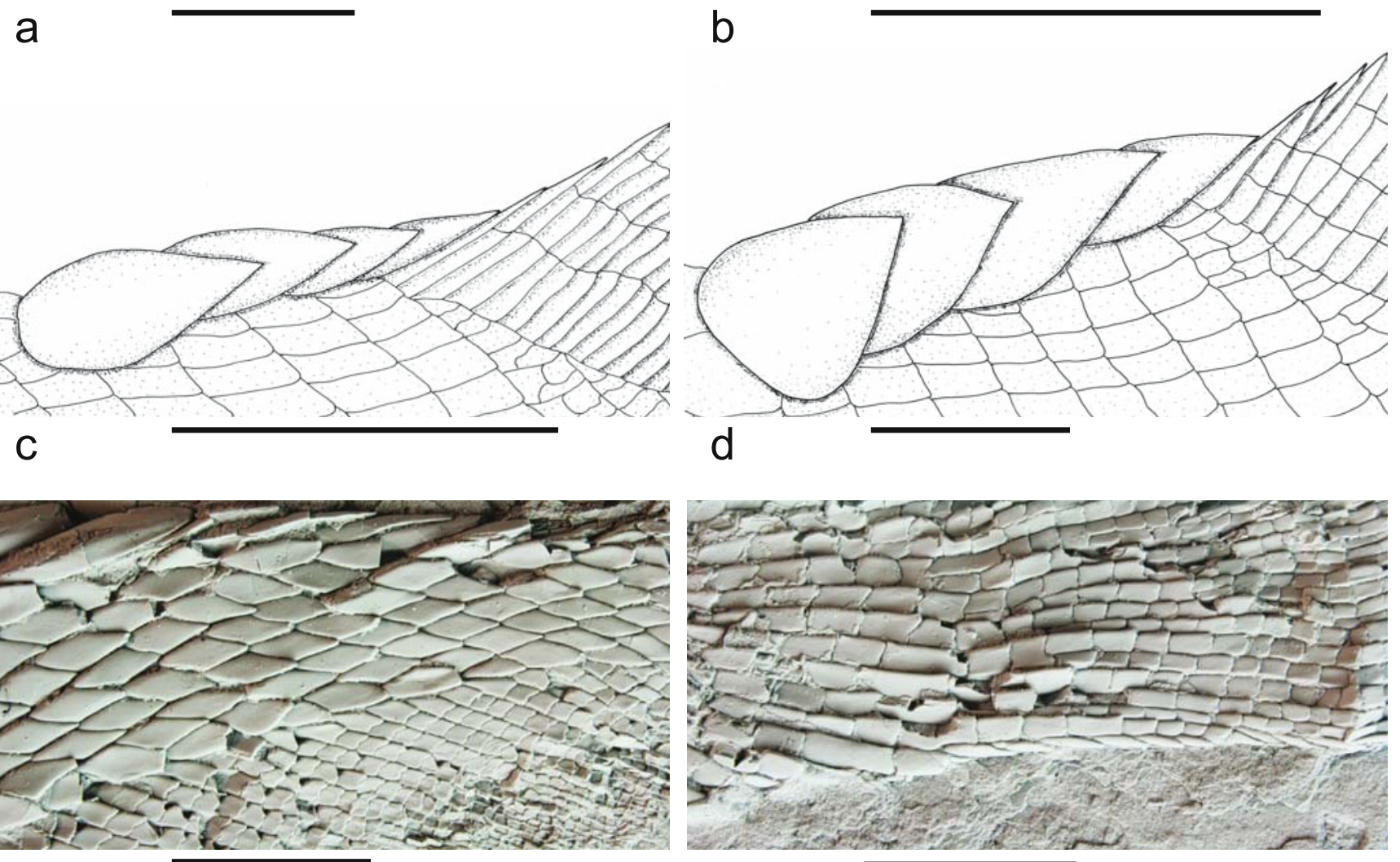

d
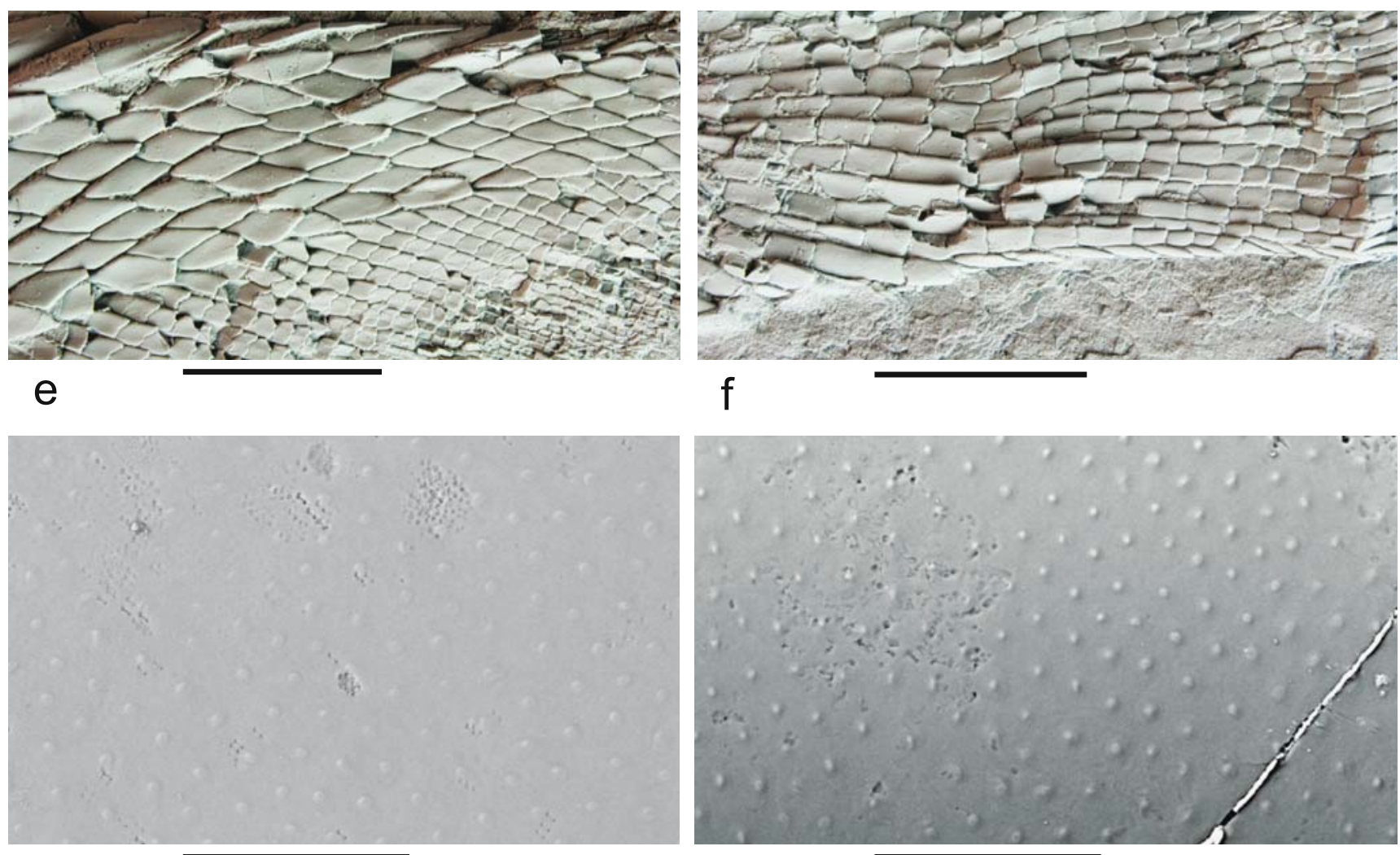

g

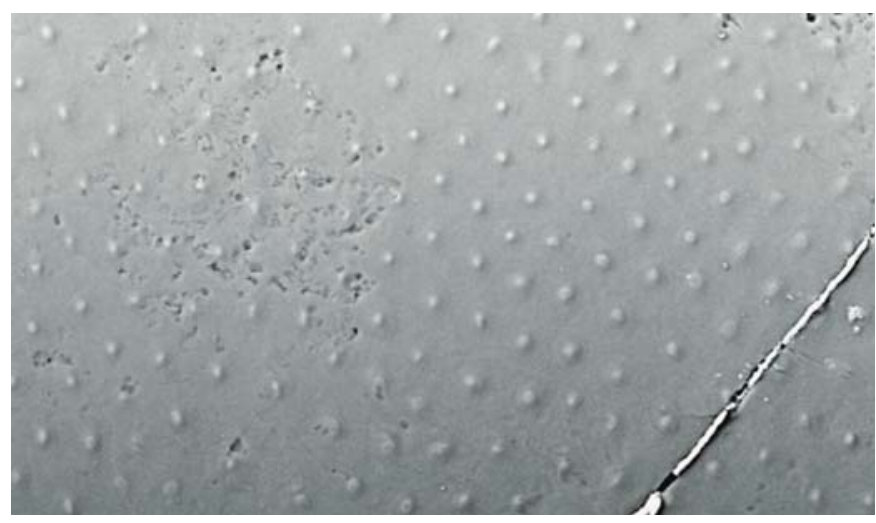

$\mathrm{h}$

Text-fig. 34. Aeduella blainvillei (Agassiz, 1833). a - ridge scales in front of the dorsal fin of a juvenile specimen (total length of the body $38 \mathrm{~mm}$ ). D 03.11.96.14. Scale bar $1 \mathrm{~mm}$. b - ridge scales in front of the dorsal fin of a juvenile specimen (total length of the body $40 \mathrm{~mm}$ ). D 26.11.95.7. Scale bar $5 \mathrm{~mm}$. c - ridge scales in front of the dorsal fin of a subadult specimen (total length of the body $80 \mathrm{~mm}$ ). D 07.06.98.10. Scale bar $5 \mathrm{~mm}$. $\mathrm{d}$ - ridge scales in front of the dorsal fin of an adult specimen (total length of the body $145 \mathrm{~mm}$ ). MHK 82809. Scale bar $5 \mathrm{~mm}$. e - part of the dorsal lobe of the caudal fin. MHK 82809, whitened. Scale bar $5 \mathrm{~mm}$. $f$ - part of the ventral lobe of the caudal fin with fringing fulcra along its anterior edge. MHK 82809, whitened. Scale bar $5 \mathrm{~mm}$. $\mathrm{g}$ - microtubercles on a scale from the lateral side of the body. Microtubercles on this and the following snaps have a round shape, and are arranged in rows. MHK 82790. Scale bar $50 \mu \mathrm{m}$. $\mathrm{h}$ - Microtubercles on a scale from the lateral side of the body. MHK 82805. Scale bar $50 \mu \mathrm{m}$. 


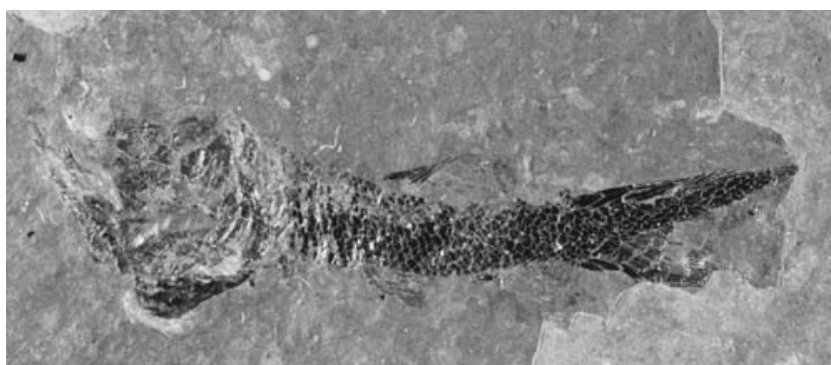

a

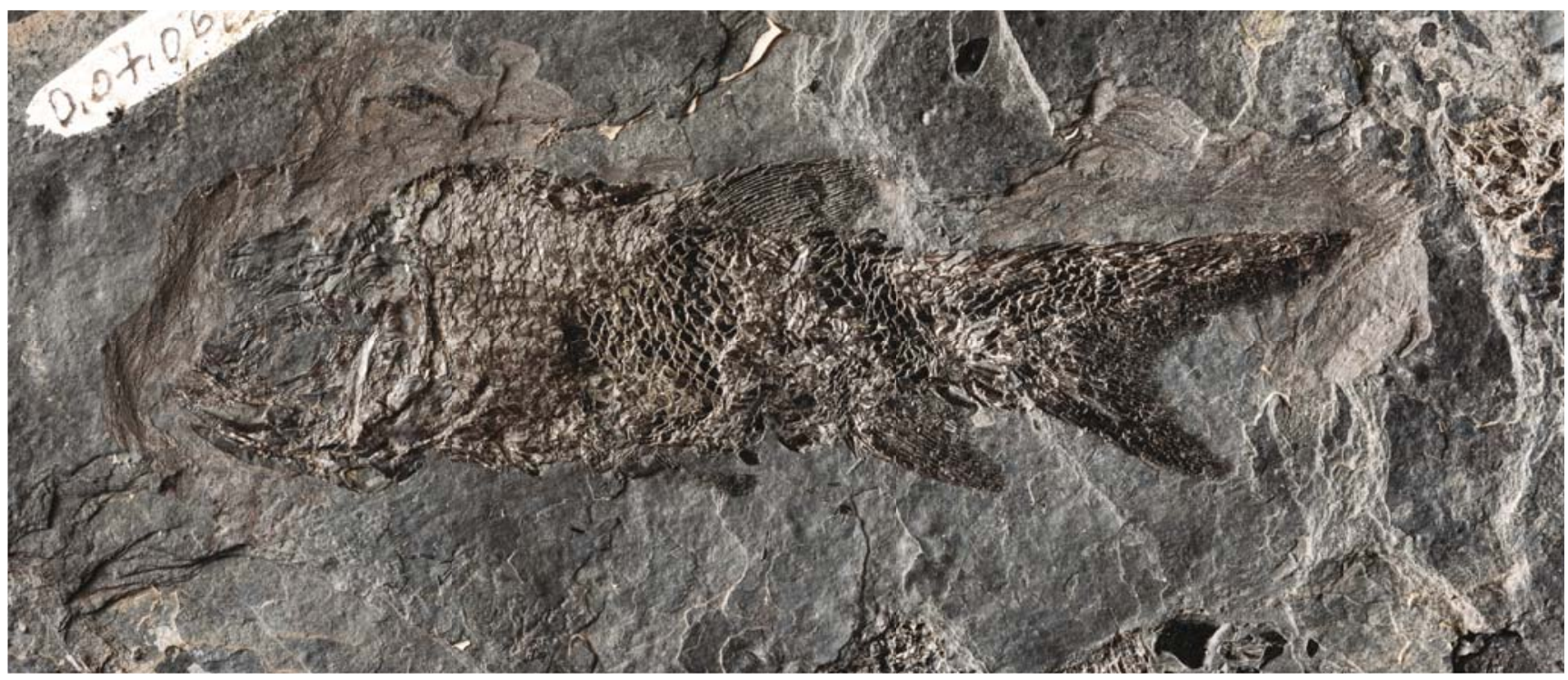

C

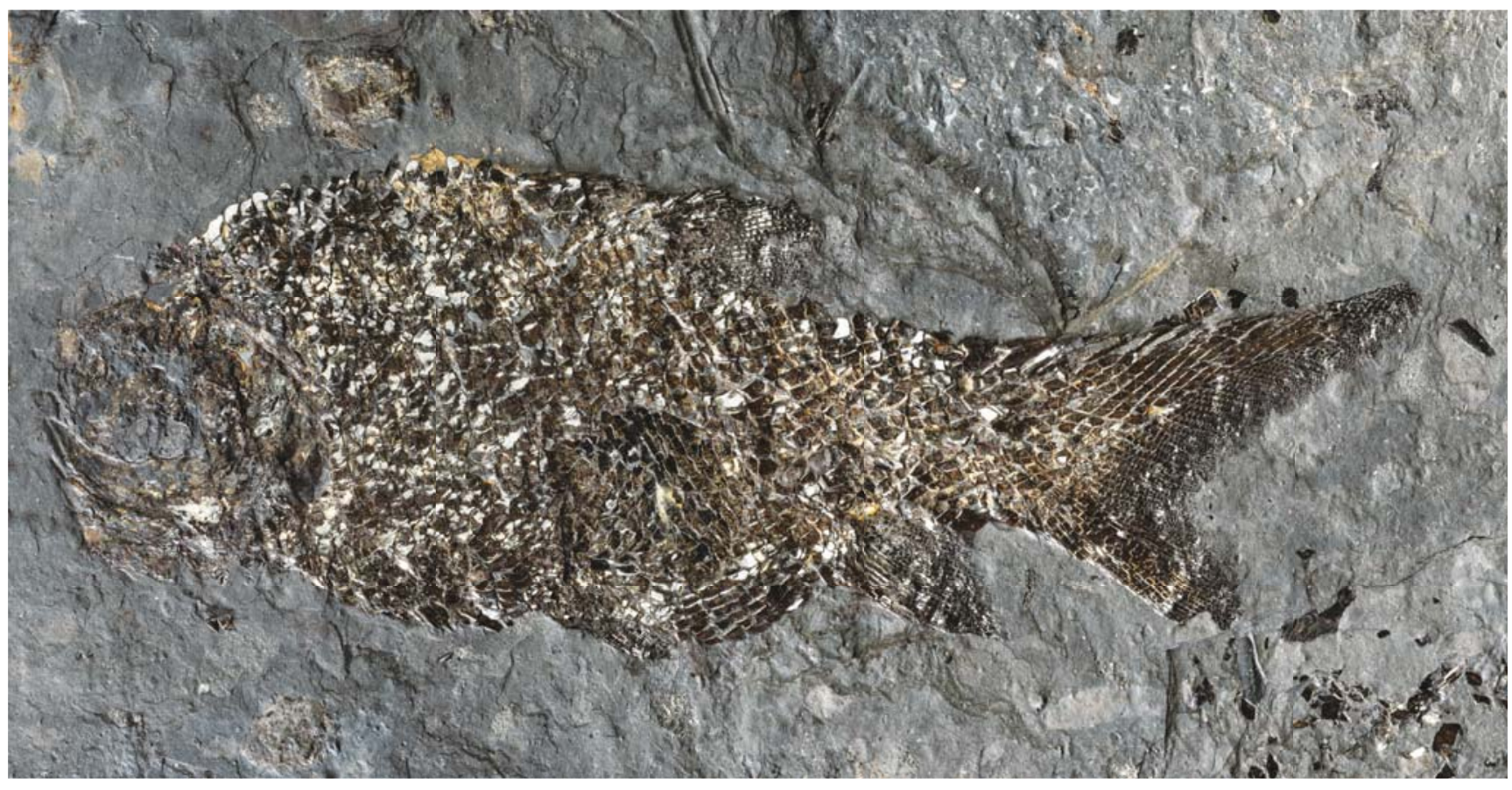

d

Text-fig. 35. Aeduella blainvillei (Agassiz, 1833). Scale bars $10 \mathrm{~mm}$. a - juvenile specimen. D 03.11.96.14. b - juvenile specimen. D 26.11.95.2. c - subadult specimen. D 07.06.98.10. $\mathrm{d}$ - adult specimen. MHK 82809.

as D 07.06.98.10 with a length of $80 \mathrm{~mm}$ (Text-fig. 35c) it represents the deepest part of the body and the ratio of the length of the skull to the total body length is 4.7. In juvenile

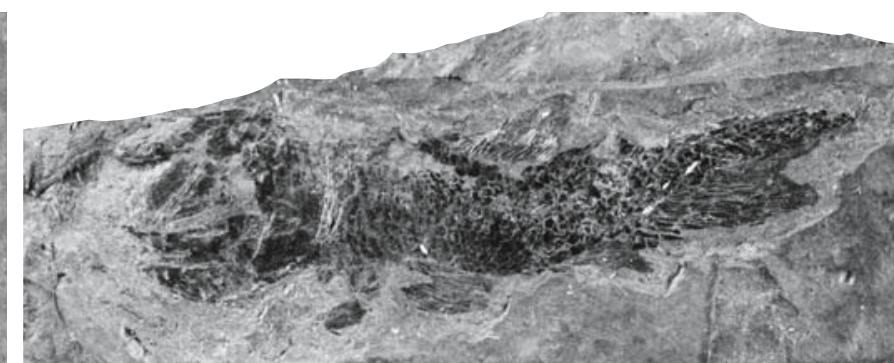

b 
in juvenile specimens have been reported as squamation is developed along the lateral sensory line only and in the dorsal part of the body it is missing. Heyler (1969: tableau I, II) gave a figure for depth of the body in juvenile specimens (Heyler 1969: pl. 37, figs 1, 2) based on unclear evidence. Measurements of adult and juvenile specimens lead to two conclusions: first, that the depth of the trunk during the course of growth increases in proportion to the total body length, and second, the length of the skull during growth of the specimen decreases in proportion to the total body length. Juvenile specimens have a well-developed large operculum in the skull (Text-fig. 35a, b).

Fins. The pectoral fin is only fragmentarily preserved. The lepidotrichia are segmented along their entire length.

The pelvic fin is situated in the middle between the pectoral and anal fins, and the base of the dorsal fin begins directly above the end of the pelvic fin.

The anal fin is triangular in shape. The base of the fin extends over a length of 8-9 scale rows. The fin contains approximately 21 segmented lepidotrichia (D 03.11.96.14; MHK 82796). The leading edge of the anal fin is protected by terminal segments of lepidotrichia in combination with fringing fulcra.

The dorsal fin is triangular in shape. The base of the fin extends over a length of 11 scale rows (D 04.11.95.19), and the fin contains 22 segmented lepidotrichia. The longest lepidotrichia in the dorsal fin of adult specimens contains more than 25 segments.

The caudal fin is attached to a strong caudal peduncle. Well-developed dorsal and anal lobes of the caudal fin produce an angle of $50^{\circ}-55^{\circ}$. The dorsal lobe is $1.6-1.8$ times as long as the ventral lobe. The ventral lobe contains 15 lepidotrichia which in adult specimens have at least 30 short robust segments in the longest lepidotrichia. The dorsal lobe contains no less than 50 lepidotrichia. The ventral lobe of the caudal fin is protected, as is the anterior border of other fins, by terminal segments of lepidotrichia in combination with the fringing fulcra (Text-fig. 34f).

Changes in the shape and number of segments in the lepidotrichia can also be recored during growth of an individual. The both anal and dorsal fins contain 21 or 22 lepidotrichia, the longest lepidotrichia contain at least 25 segments, and similarly, the ventral lobe of the caudal fin has 15 lepidotrichia with at least 30 short robust segments. While the number of lepidotrichia in the fins of juvenile and adult specimen is the same, however the number and shape of segments in juvenile specimens differ significantly. The segments in juvenile specimen D 26.11.95.2, with a total body length of $36 \mathrm{~mm}$, are very slender and there are only four segments in the longest lepidotrichia of the pelvic fin, five segments make up the lepidotrichia of the dorsal fin, and the longest lepidotrichia in the ventral lobe of the caudal fin consists of seven segments. The number of segments increases with growth of the individual. Specimen D 07.06.98 which is $80 \mathrm{~mm}$ in total body length has 12 segments in the longest lepidotrichia of both the anal and dorsal fins. These conclusion agree with the data published by Heyler (1969: 147) for Aeduella blainvillei and Štamberg (2007, 2010b) for Neslovicella rzehaki and Neslovicella elongata.

Squamation. The scales on the anterior part of the trunk along the lateral sensory line are of oblong shape and are serrated posteriorly. The serrations occupy $2 / 3$ of the posterior margin (MHK 82790; MHK 82801). The scale count is:

$\begin{array}{lll} & 22 \\ 8 \quad 21 \quad 32 & 36\end{array}$

Six scales are above the lateral sensory line and six scales are below it in the oblique scale range in front of the pelvic fin base in juvenile specimen D 04.11.95.20. In front of some fins are large ridge scales. Four ridge scales precede the dorsal fin. Their shape is variable depending on the age of the specimen. Ridge scales in juvenile specimens are slender and elongated in an anteroposterior direction (Text-fig. 34a). Only the first scale is entire, those following are produced by a coalescence of two scales. The scales grow together gradually during growth of the specimen (Text-fig. 34b), and the scales gradually broaden (Text-fig. 34c, d). Large paired ridge scales precede the base of the anal fin. These scales protect the dorsal margin of the caudal peduncle and two ridge scales cover the ventral margin of the caudal peduncle.

Distinctive microsculpture characterises the scales of Aeduella blainvillei. Typically this consists of tubercles with a circular base which are arranged at regular distances (Textfig. $34 \mathrm{~g}, \mathrm{~h}$ ). These tubercles are similar to the short ridges forming the microsculpture of Progyrolepis heyleri scales and are typical for ganoine surfaces. The tubercles forming the microsculpture of Aeduella blainvillei have the same shape and arrangement as those forming the scale microsculpture of Paramblypterus duvernoy (personal observation), and the scales of Aeduella blainvillei and Paramblypterus duvernoy cannot be distinguished on the basis of their microsculpture at present. Monitoring the microsculpture of scales is very important as already Meunier et al. (1986), Gayet and Meunier (2001) demonstrated in recent and fossil genera of Lepisosteiformes and Polypteriformes. The shape and arrangement of microtubercles can also be used for determination of isolated scales of PermoCarboniferous actinopterygians as shown in the comparison of microtubercles of Progyrolepis heyleri (Text-figs 23b, 24), "Elonichthys" sp. (Štamberg 2016b), Igornichthys bohemicus ŠTAMBERG, 2016 (Štamberg 2016a), Spinarichthys dispersus (Štamberg 2016b) and others. This comparison of scale microsculpture in the above mentioned species shows differences in shape and arrangement of microtubercles.

\section{Amblypteridae Romer, 1945}

\section{Genus Paramblypterus SAUvage, 1888}

Ty p e s pecies. Paramblypterus decorus (EGERTon, 1850).

Diagnosis. After Dietze (1999) and Štamberg (2013b). Nasal bones split secondarily. Dermohyal not present as a single ossification. More than two suborbitals. Seven to nine branchiostegal rays. No gap between the opercular series and skull roofing bones. Duplication of the extrascapular series (postparietals) is present. Scales weakly serrated, with little ornamentation.

Included species. Paramblypterus decorus (Egerton, 1850); Paramblypterus duvernoy (Agassiz, 1933); P. gelberti (Goldfuss, 1847); P. rohani (Heckel, 
1861); P. reussii (Heckel, 1861); P. comblei Heyler, 1969; P. vratislaviensis (Agassiz, 1833); P. kablikae (GEINITZ, 1860); P. feistmanteli (FriTsCH, 1895); P. zeidleri (FrITSCH, 1895).

\section{Paramblypterus cf. duvernoy}

\section{Text-fig. 36}

Description. Operculo-gular series (BUX 22), parietal(BUX 45) and skull roof(BUX 86) of Paramblypterus sp. from Buxières-les-Mines were described and figured by Heyler (1984, 2000) and Heyler and Poplin (1990). A well preserved unit of the skull roof was found in the studied collection, and it complements our overview of the actinopterygians of Buxières-les-Mines.

Specimen D 11.11.95.9 exhibits a well preserved skull roof unit (Text-fig. 36). The frontal is oblong in shape, has a strongly curved interfrontal suture, and a lateral process on the lateral side of the frontal that projects between the dermosphenotic and dermopterotic. The triangular dermosphenotic and oblong dermopterotic are arranged in one row. The dermopterotic borders the posterior half of the frontal and whole lateral margin of the parietal laterally, and it projects posterolaterally towards the process. The parietal shows three pit lines posterolaterally. The exposed surface of the bones bears ridges and tubercles which form conspicuous sculpture.

The above description of the skull roof bones together with the earlier descriptions by Heyler $(1984,2000)$ and Heyler and Poplin (1990) include the same characteristic features corresponding to Paramblypterus rohani from Surmoulin in France (Heyler 1971), Paramblypterus duvernoy from the Saar Basin, Germany (Dietze 1999, 2000) and Paramblypterus rohani from Krkonoše Piedmont Basin, the Czech Republic (Štamberg 1976). The most recent research (Dietze 2000, Štamberg 2013a, b) on $P$. duvernoy and $P$. rohani indicates there is a great similarity between these two species, and they could be considered one species. Based on priority, they should be considered Paramblypterus duvernoy (AGAssiz, 1833). I believe the present description plus the skull roof, operculo-gular series and parietal described by Heyler $(1984,2000)$ and Heyler and Poplin (1990) are also similar to Paramblypterus duvernoy (AgAssiz, 1833).

\section{Conclusions}

Actinopterygians from the large opencast coal mine in the vicinity of the village of Buxières-les-Mines (Bourbonl'Archambault Basin, Allier, France) are revisited and redescribed based on newly studied specimens. Knowledge regarding the jaws which are of vital importance for designation of Progyrolepis heyleri was greatly enhanced, including changes in the shape of the maxilla during ontogenesis. Completely new information about the construction of the palatoquadrate, dermal bones of the skull roof, opercular apparatus and the shoulder girdle was gained. Characteristics regarding the squamation were identified and described, including microsculpture on scales, and specialised scales in front of the fins. Some information was gained in regards to the bones of the rostral part of the skull, around the orbit, and the ventral portion of the operculogular series. The collection of whole individuals, body fragments and numerous isolated bones provide confirmation of the presence of Aeduella blainvillei which is the main component of the actinopterygian fauna in Buxières-lesMines. Additional new knowledge was obtained regarding the great variability in bones of the opercular apparatus and maxilla, presence of the supraorbital, branchiostegal ray with a conspicuous hyoid process and the direction of mutual overlapping of the suboperculum and branchiostegal ray in Aeduella blainvillei. Microsculpture on the scales is redescribed in this species. Paramblypterus cf. duvernoy is the third member of the actinopterygians in the locality Buxières-les-Mines. Fragments of Paramblypterus are

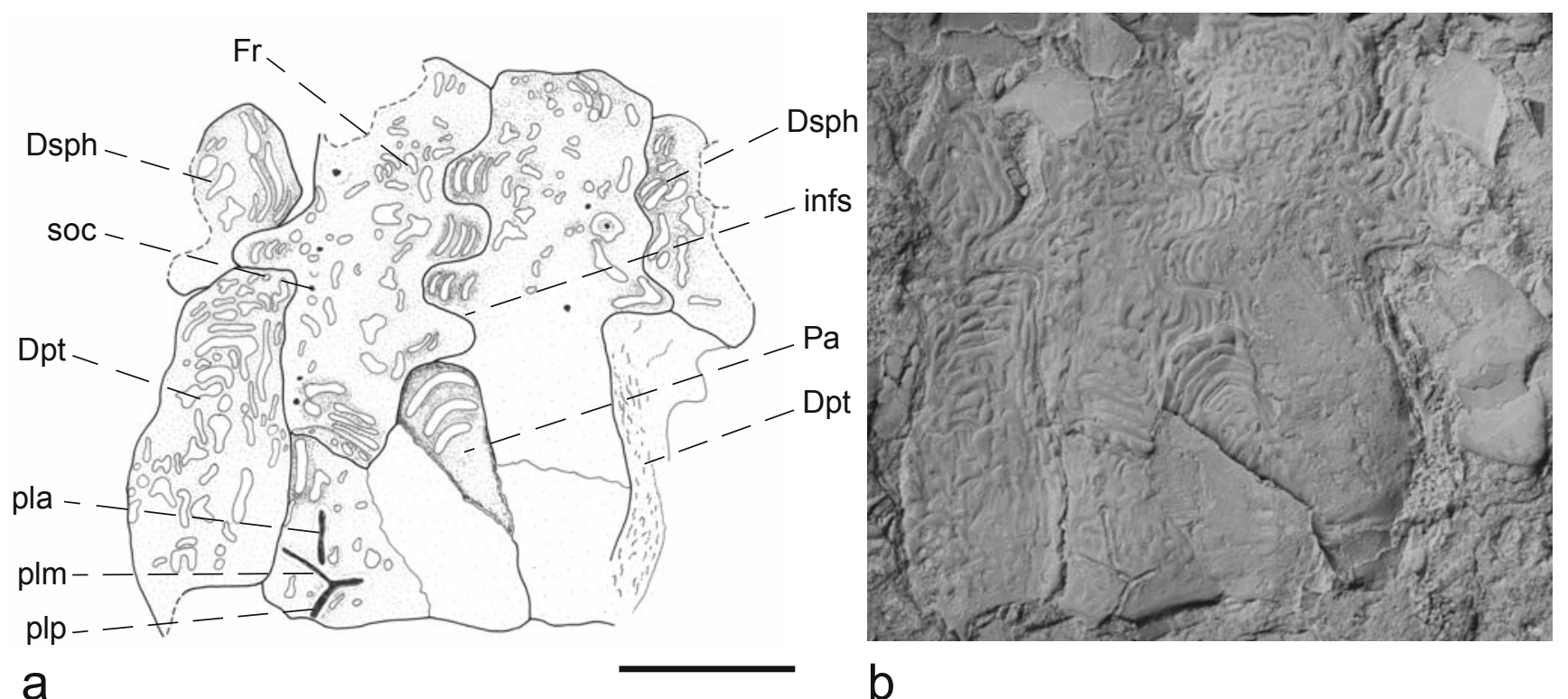

Text-fig. 36. Paramblypterus cf. duvernoy. a, b - photograph and drawing of the skull in dorsal view. D 11.11.95.9, whitened. Scale bar 5 mm. Abbreviations: Dsph - dermosphenotic; Dpt - dermopterotic; Fr - frontal; infs - interfrontal suture; Pa - parietal; pla - pit line anterior; plm - pit line medial; plp - pit line posterior; soc - supraorbital canal. 
very rare and the bones of the skull roof are presented here. Anatomical features of Progyrolepis heyleri, Aeduella blainvillei and Paramblypterus cf. duvernoy were studied and compared with those of other Devonian and PermoCarboniferous actinopterygians.

\section{Environment}

A lacustrine environment can be assumed for the section of organic rich gray-black shales containing actinopterygians (Steyer et al. 2000). The sediments from Buxières-lesMines produced a large quantity of osteological fragments and occasionally whole specimens of actinopterygians. Isolated bones and scales of Aeduella blainvillei prevail, but also whole specimens, especially from juvenile individuals are not uncommon. On the contrary Paramblypterus cf. duvernoy is very rare, and only isolated bones or parts of the skull roof complex or operculo-gular series are known. The carnivorous fish Progyrolepis heyleri is relatively common as reflected by the fragments of bodies, isolated bones and scales but the whole specimen is still unknown. Skeletal fragments and scales of Progyrolepis heyleri and Aeduella blainvillei are found mixed together, and they are also frequently mixed with the scales and fragments of Acanthodes and other aquatic vertebrates. It is obvious that between the death of the specimen and its being covered with sediment, a relatively long time had elapsed when decomposition of the body into bones and scales and their subsequent transport occurred. Large local accumulations of bones and scales show that the actinopterygian skeletal remains fell out of the water column in calm places without any water flow and where the process of decay could continue. If living actinopterygians would by chance happen to be in these places of mass decomposition and oxygen deficiency, they also died. This was probably the case for the juvenile specimens of Aeduella blainvillei which often occurred as whole fish among the accumulation of isolated bones and scales. It is clear that these individuals died in situ and their cadavers were not transported in the water column. Most individuals, however, show some signs of post-mortem decomposition and transport. Sample MHK 82771 for example exhibits in addition to the spine of Acanthodes, three isolated opercular bones which represent three ontogenetic stages of Aeduella blainvillei. The smallest operculum belonged to a juvenile specimen of total length $55 \mathrm{~mm}$, the second operculum belonged to a specimen of total length $120 \mathrm{~mm}$ and the largest operculum and cleithrum were from an adult specimen of $150 \mathrm{~mm}$ in total length.

The occurence of Aeduella blainvillei, Progyrolepis heyleri and Paramblypterus $\mathrm{cf}$. duvernoy plus the presence of other species of Elasmobranchii, Acanthodii and Amphibia which are also known from many other European basins testify to the interconnection of these basins. The Buxièresles-Mines Basin was interconnected not only with the basins in the French Massif Central but also with the Saar and Thuringian Basins in Germany, plus with the Puertollano Basin in Spain and the Czech basins in the Bohemian Massif. The family Aeduellidae exhibited a great expansion in the Permo-Carboniferous basins. Aeduella blainvillei occurred in addition to the Massif Central in France, also in the Saar Basin in Germany and the Krkonoše Piedmont Basin in the Bohemian Massif. Even greater expansion was achieved by the genus Bourbonnella which is known from Bourbon-l'Archambault Basin (Allier, France) and some other basins of the Massif Central, and it also occurs in the Spanish Puertollano Basin, Boskovice Graben in the Bohemian Massif plus in New Mexico and Utah in the USA. The presence of Bourbonnella in the marine environment in New Mexico (Gottfried 1987) and large expansion of the genus, led Poplin (2001) to conclude that it is a euryhaline genus occurring in the tropical environment of the Late Carboniferous and Early Permian. It can be presumed that suitable conditions for interbasin connection were through the river system, and interconnection of the Bohemian basins with some basins in Germany were through the Elbe lineament for migration of fauna (Boy and Schindler 2000, Štamberg 2010b). Boy and Schindler (2000), Schultze (2009), Schultze and Soler-Gijón (2004) recorded great similarity between the Permo-Carboniferous fauna of the French Central basins, Saare Basin, the basins of the Germany Central and Bohemian basins. Schultze (2009), Schultze and Soler-Gijón (2004) also recorded some similarities with the basins of North America; they concluded that migration of fauna from one basin to another through the Palaeotethys was the most probable option.

The occurence of actinopterygians in the Buxières-lesMines can be clearly compared with the actinopterygians of the Permo-Carboniferous basins in the Bohemian Massif. If we also include Acanthodii with the Actinopterygii in a comparison of fauna, the layers of the Suprabuxières Members of the Buxières Formation with actinopterygians could be Asselian - Sakmarian in age in the light of this research.

\section{Acknowledgements}

I am greatly obliged to Francois Esçuillié and Jean-Marc Pouillon, representatives of the Association Rhinopolis in Gannat, for inviting me to carry out research in the Buxières-les-Mines locality and allowing me to borrow the actinopterygians for study. I would also like to thank Lenka Váchová (National Museum, Prague) for Electron Microscope photographs, to Miroslav Beneš for the photos of some specimens, and to Gill Horalek for correction of the English. Special thanks are due to reviewers Thomas Schindler and Kathryn E. Mickle for their fruitful comments and suggestions, which improved the final version of the manuscript. Finally, I would like to thank Jan Wagner (National Museum, Prague) for careful technical preparation of the manuscript for printing. This study is a part of the internal research project of the Museum of Eastern Bohemia in Hradec Králové, No 180021.

\section{References}

Agassiz, L. (1833 - 1843): Recherches sur les Poissons fossiles (5 vols.). - Aux frais de l'auteur, Neuchâtel, 1420 pp.

Aldinger, H. (1937): Permische Ganoidfische aus Ostgrönland. - Meddelelser om Grønland, 102(3): 1-392. 
Arratia, G., Cloutier, R. (1996): Reassessment of the morphology of Cheirolepis canadensis (Actinopterygii). In: Schultze, H.-P., Cloutier, R. (eds), Devonian fishes and plants of Miguasha, Quebec, Canada. - Verlag Dr. Friedrich Pfeil, München, pp. 165-197.

Arratia, G., Schultze, H.-P. (1991): Palatoquadrate and its ossifications: development and homology within osteichthyans. - Journal of Morphology, 208: 1-81. https://doi.org/10.1002/jmor.1052080102

Berg, L. S. (1941): [Lower Triassic fishes of the Tunguska coal basin, Yenisei, Siberia]. - Bulletin of the Academy of Sciences of the USSR, 3: 458-474. (in Russian)

Blainville, H. M. (1818): Poissons fossiles. - In: Levrault, F. G. (ed.), Nouveau dictionnaire d'histoire naturelle, appliquée aux arts, à l'agriculture, à l'économie rurale et domestique, à la médecine, etc., Tome 27. Chez Deterville, Paris, pp. 310-395.

Blot, J. (1966): Étude des Palaeonisciformes du Bassin de Commentry [series Cahiers de paléontologie]. - Éditions du Centre national de la recherche scientifique, Paris, 99 pp.

Boy, J. A., Schindler, T. (2000): Ökostratigraphische Bioevents im Grenzbereich Stephanium/Autunium (höchstes Karbon) des Saar-Nahe-Beckens (SW-Deutschland) und benachbarter Gebiete. - Neues Jahrbuch für Geologie und Paläontologie, Abhandlungen, 216(1): 89-152. https://doi.org/10.1127/njgpa/216/2000/89

Bronn, H. (1829): Ueber die Fisch-Abdrücke in EisensteinNieren des Mittel-Rheinischen Steinkohlen-Gebirges, und über Palaeoniscum macropterum n. sp. insbesondere. - Zeitschrift für Mineralogie, 2: 483-493.

Choo, B. (2011): Revision of the actinopterygian genus $M i$ mipiscis (= Mimia) from the Upper Devonian Gogo Formation of Western Australia and the interrelationships of the early Actinopterygii. - Earth and Environmental Science Transactions of the Royal Society of Edinburgh, 102: 77-104. https://doi.org/10.1017/S1755691011011029

Cope, E. D. (1877): On the Vertebrata of the bone bed in Eastern Illinois. - Proceedings of the American Philosophical Society, 17: 52-63.

Dietze, K. (1999): Paramblypterus duvernoyi (Actinopterygii): Skull, morphology and intra-specific variation, and its implications for the systematics of paramblypterid fishes. - Journal of Vertebrate Paleontology, 19(2): 247-262.

https://doi.org/10.1080/02724634.1999.10011139

Dietze, K. (2000): A revision of paramblypterid and amblypterid actinopterygians from Upper Carboniferous - Lower Permian lacustrine deposits of Central Europe. - Palaeontology, 43(5): 927-966. https://doi.org/10.1111/1475-4983.00156

Egerton, P. (1850): Palichthyologic Notes. No. 3. On the Ganoidei Heterocerci. - Quarterly Journal of the Geological Society, London, 6: 1-10.

https://doi.org/10.1144/GSL.JGS.1850.006.01-02.05

Esçuillié, F., Steyer, J.-S., Pouillon, J. M., Rage, J. C. (1996): Buxières-les-Mines (Allier, France), un important site paléontologique permien (ré)exploité en auvergne: une coopération industrie/Paléontologie. - "Paléontologie 2000", Deuxième Congrès National de Paléontologie, Paris, nov. 96. Abstract, p. 29.
Fischer, J., Schneider, J. W., Voigt, S., Joachimski, M. M., Tichomirowa, M., Tütken, T., Götze, J., Berner, U. (2013): Oxygen and strontium isotopes from fossil shark teeth: Environmental and ecological implications for Late Palaeozoic European basins. - Chemical Geology, 342(2013): 44-62.

https://doi.org/10.1016/j.chemgeo.2013.01.022

Forey, P. L., Young, V. T. (1985): Upper Stephanian fishes from the Puertollano Basin, Ciudad Real, Spain. - Anais Faculdade de Ciencias do Porto, 64(1983): 233-244.

Frič, A. (1875): Über die Fauna der Gaskohle der Pilsner und Rakonitzer Beckens. - Sitzungsberichte königl. böhmischen Gesellschaft der Wissenschaften in Prag, 1875: 70-79.

Frič, A. (1877): Zur Fauna der Gaskohle von Zaboř bei Schlan, Kroučová bei Řenč und Třemošná bei Pilzen, sowie über die Sphaerosideritkugeln von Žilov. - Sitzungsberichte königl. böhmischen Gesellschaft der Wissenschaften in Prag, 1877: 45-52.

Friedrich, P. A. (1878): Das Rothliegende und die basischen Eruptivgesteine in der Umgebung des grossen Inselsbergs. - Zeitschrift für der gesamten Naturwissenschaften, 51: 719-770.

Fritsch, A. (1883): Fauna der Gaskohle und der Kalksteine der Permformation Böhmens. Bd. I, H. 4. - F. Řivnáč, Prag, pp. 159-182.

Fritsch, A. (1894): Fauna der Gaskohle und der Kalksteine der Permformation Böhmens. Bd. III, H. 2. - F. Řivnáč, Prag, pp. 81-104.

Fritsch, A. (1895): Fauna der Gaskohle und der Kalksteine der Permformation Böhmens. Bd. III, H. 4. - F. Řivnáč, Prag, pp. 105-132.

Gardiner, B. G. (1963): Certain Palaeoniscoid fishes and the evolution of the snout in Actinopterygians. - Bulletin of the British Museum (Natural History), Geology, 8(6): 257-325.

Gardiner, B. G. (1984): The relationships of the palaeoniscoid fishes, a review based on new specimens of Mimia and Moythomasia from the Upper Devonian of Western Australia. - Bulletin of British Museum (Natural History), Geology series, 3(4): 173-428.

Gardiner, B. G., Bartram, A. W. H. (1977): The homologies of ventral cranial fissures in osteichthyans. - In: Andrews, S. M., Miles, R. S., Walker, A. D. (eds), Problems in Vertebrate Evolution: Essays Presented to Professor T. S. Westoll. Linnean Society symposium series, 4: 227-245.

Gardiner, B. G., Schaeffer, B., Masserie, J. A. (2005): A review of the lower actinopterygian phylogeny. - Zoological Journal of the Linnean Society, 144: 511-525. https://doi.org/10.1111/j.1096-3642.2005.00181.x

Gayet, M., Meunier, F. J. (2001): A propos de genre Paralepidosteus (Ginglymodi, Lepisosteidae) du Crétacé Gondwanien. - Cybium, 25(2): 153-159.

Geinitz, H. B. (1860): Zur Fauna des Rotliegenden und Zechsteins. - Zeitschrift der Deutschen Geologischen Gesellschaft, 12(3): 467-470.

Giebel, C. G. (1848): Fauna der Vorwelt mit steter Berücksichtigung der lebenden Thiere. Erster Band: Wirbelthiere. Dritte Abtheilung: Fische. - F. A. Brockhaus, Leipzig, 467 pp. 
Goldfuss, G. A. (1847): Beiträge zur vorweltlichen Fauna des Steinkohlengebirges. - Henry \& Cohen, Bonn, $26 \mathrm{pp}$.

Gottfried, M. (1987): A Pennsylvanian aeduelliform (Osteichthyes, Actinopterygii) from North America with comments on aeduelliform interrelationships. - Paläontologische Zeitschrift, 61: 141-148.

https://doi.org/10.1007/BF02985947

Grande, L., Bemis, W. (1998): A comprehensive phylogenetic study of amiid fishes (Amiidae) based on comparative skeletal anatomy. An empirical search for interconnected patterns of natural history. - Journal of Vertebrate Paleontology, 18(1 - suppl., Memoir 4): 1-690. https://doi.org/10.1080/02724634.1998.10011114

Heckel, W. J., Kner, R. (1861): Neue Beiträge zur Kenntniss der fossilen Fische Österreichs. - Denkschriften der Kaiserlichen Akademie der Wissenschaften, Mathematischnaturwissenschaftliche Classe, 19: 49-63.

Heyler, D. (1964): A proposde quelques Vertébrés fossiles de l'Autunien (?) de Decazeville. - L'Eduen Bulletin de la Société d'Histoire Naturelle d'Autun, 31: 6-14.

Heyler, D. (1967): Quelques points nouveaux au sujet d'Aeduella Westoll. - Colloques internationaux du Centre national de la Recherche scientifique, 163: 81-88.

Heyler, D. (1969): Vertébrés de l'Autunien de France [series Cahiers de paléontologie]. - Éditions du Centre national de la recherche scientifique, Paris, 312 pp.

Heyler, D. (1971): Sur des os de Paramblypterus du gisement de Surmoulin. - Bulletin de la Société d'Histoire naturelle d'Autun, 57: 3-14.

Heyler, D. (1977): Découvertes ichthyologiques dans le Permien de Lodève; une nouvelle structure dentaire. - Géologie méditerranéenne, 4(3): 189-204. https://doi.org/10.3406/geolm.1977.100

Heyler, D. (1984): Faune fossile du Permien de l'Allier. - In: Revue Scientifique du Bourbonnais, pp. 103-122.

Heyler, D. (2000): Les Actinoptérygiens stéphaniens et autuniens du Massif Central (France) dans les collections du M.N.H.N. (Paris) et du Muséum d'Autun: compléments, mises au point, bilan. - Bulletin de la Société d'Histoire naturelle d'Autun, 169(1999): 7-44.

Heyler, D. (2002): Inventaire des Vertébrés de l'Autunien de Bourbon-1'Archambault (Allier) dans les collections du MNHN (Laboratoire de Paléontologie) et un nouveau Platysella. - In: Revue Scientifique du Bourbonnaise, pp. $17-40$.

Heyler, D., Poplin, C. (1983): Actinoptérygiens du Stéphanien de Montceau-les-Mines (Saône-et-Loire, France). Palaeovertebrata, 13: 33-50.

Heyler, D., Poplin, C. (1990): Les Vertébrés autuniens de Buxières-les-Mines (Allier, France). - Bulletin du $\mathrm{Mu}-$ séum national d'histoire naturelle, 12(4): 225-239.

Kazanceva-Selezneva, A. A. (1977): K sisteme i filogenii otryada Palaeonisciformes [System and Phylogeny of the Order Palaeonisciformes]. - In: Ocherki po filogenii i sistematike iskopaemykh ryb i bezchelyustnych [Studies in the Phylogeny and Systematics of Agnathans and Fishes]. Akad. Nauk, Moscow, pp. 98-116. (in Russian)

Lehman, J.-P. (1952): Étude complementaire des poissons de l'Eotrias de Madagascar. - Kungl. Svenska vetenskapsakademiens handlingar, Ser. 4, 2(6): 1-201.
Linnaeus, C. (1758): Systema naturae per regna tria naturae, secundum classes, ordines, genera, species, cum characteribus, differentiis, synonymis, locis. Vol. 1 ( $10^{\text {th }}$ ed.). - Laurentii Salvii, Holmiae, 824 pp.

Long, J. A. (1988): New palaeoniscoid fishes from the Late Devonian and Early Carboniferous of Victoria. - Memoires of the Association of Australasian Palaeontologists, 7: 1-64.

Meunier, F. J., Gayet, M., Géraudie, J., Sire, J.-Y., Zylberberg, L. (1986): Données Ultrastructurales sur la Ganoïne du Dermosquelette des Actinoptérygiens Primitifs. - Mémoires du Muséum d'histoire naturelle, Paris, Sér. C, 53: 77-83.

Mickle, K. E. (2011): The early actinopterygian fauna of the Manning Canyon Shale Formation (Upper Mississippian, Lower Pennsylvanian) of Utah, U.S.A. - Journal of Vertebrate Paleontology, 31(5): 962-980. https://doi.org/10.1080/02724634.2011.595622

Nielsen, E. (1942): Studies on Triassic fishes from East Greenland. I. Glaucolepis and Boreosomus. - Meddelelser om Grønland, 138: 1-403.

Nielsen, E. (1949): Studies on Triassic fishes from East Greenland. II. Australosomus and Birgeria. - Meddelelser om Grønland, 146(1): 1-309.

Paquette, Y., Feys, R. (1989): Le Bassin de Bourbon-l'Archambault (Aumance). - In: Chateauneuf, J.-J., Farjanel, G. (eds), Synthèse geologique des bassins permiens français. Mémoires du Bureau de recherches géologiques et minières, 128: 43-54.

Pearson, D. M., Westoll, T. S. (1979): The Devonian actinopterygian Cheirolepis Agassiz. - Transactions of the Royal Society of Edinburgh, 70: 337-399. https://doi.org/10.1017/S0080456800012850

Pohlig, H. (1892): Permische Sauriefährten, Fische und Medusen der Gegend von Friedrichroda. - In: Festschrift zum 70. Geburtstage R. Leuckarts. W. Engelmann, Leipzig, pp. 59-64.

Poplin, C. (1999): Un paléoniscoide (Pisces, Actinopterygii) de Buxières-les-Mines, témoin des affinités fauniques entre Massif central et Bohême au passage CarbonifèrePermien. - Geodiversitas, 21(2): 147-155.

Poplin, C. (2001): Le genre Bourbonnella (Actinopterygii, Aeduellidae): révision et description d'une nouvelle espèce du Stéphanien (Carbonifère supérieur) de Montceau-les-Mines (Massif Central, France). - Annales de Paléontologie, 87(4): 231-248. https://doi.org/10.1016/S0753-3969(01)80012-4

Poplin, C., Dutheil, D. B. (2005): Les Aeduellidae (Pisces, Actinopterygii) carbonifères et permiens: systématique et étude phylogénétique préliminaire. - Geodiversitas, 27(1): 17-33.

Poplin, C., Heyler, D. (1993): The marginal teeth of the primitive fossil actinopterygians: systematics and evolution. - In: Heidtke, U. (ed.), New Research on Permo-Carboniferous Faunas. Pollichia-Buch, 29: 113-124.

Poplin, C., Lund, R. (1997): Evolution of the premaxillary in the primitive fossil actinopterygians. - Geodiversitas, 19(3): 557-565.

Poplin, C., Véran, M. (1996): A revision of the actinopterygian fish Cococephalus wildi from the Upper Carboniferous of Lancashire. - In: Milner, A. R. (ed.), Studies on Carboniferous and Permian vertebrates. Special Papers in Paleontology, 52: 7-29. 
Richter, M. (1983): Ultra-estrutura de dentes de Paleoniscídeos (Pisces) do Grupo Passa Dois, RS, Brasil. - Iheringia, Sér. Geol., Porto Alegre, 8: 131-145.

Richter, M. (1995): Actinopterygian scale microstructure as a tool in the biostratigraphy of the Palaeozoic. - Buletin de la Academia Nacional de Ciencias, Cordoba, 60(3-4): 545-553.

Romer, A. S. (1945): Vertebrate Paleontology ( $2^{\text {nd }}$ ed.). University of Chicago Press, Chicago, $687 \mathrm{pp}$.

Roscher, M., Schneider, J. W. (2006): Permo-Carboniferous climate: Early Pennsylvanian to Late Permian climate development of central Europe in a regional and global context. - In: Lucas, S. G., Cassinis, G., Schneider, J. W. (eds), Non-Marine Permian Biostratigraphy and Biochronology. Special Publications, Geological Society, London, 265: 95-136.

https://doi.org/10.1144/GSL.SP.2006.265.01.05

Sauvage, H. E. (1888): Poissons du terrain Houiller de Commentry. - In: Études sur le terrain Houiller de Commentry, Livre 3 - Faunes ichthyologique et entomologique, pt. 1. Société de L'Industrie Minérale, St-Etienne, pp. 39-120.

Schindler, T. (1993): "Elonichthy" palatinus n. sp. a new species of actinopterygians from the Lower Permian of the Saar-NaheBasin (SW-Germany), with the description of a new palaeoniscoid (Osteichthyes, Actinopterygii). In: Heidtke, U. (ed.), New Research on Permo-Carboniferous Faunas. Pollichia-Buch, 29: 67-81.

Schindler, T. (2017): Neubeschreibung, Rekonstruktion, Paläoökologie und Paläobiogeografie von Elonichthys fritschi Friedrich, 1878 (Osteichthyes, Actinopterygii; Unterperm, Deutschland). - Mainzer naturwissnschaftliches Archiv, 54: 83-96.

Schindler, T. (2018a): Neubeschreibung und erste Rekonstruktion von Elonichthys germari Giebel, 1848 (Pisces, Actinopterygii; Oberkarbon, Mitteldeutschland). - Hallesches Jahrbuch für Geowissenschaften, 41: 1-33.

Schindler, T. (2018b): Revision of Rhabdolepis macropterus (Bronn, 1829) (Osteichthyes, lower Actinopterygii; Lower Permian, SW Germany). - PalZ, 92(4): 651-660. https://doi.org/10.1007/s12542-018-0410-z

Schneider, J. W., Werneburg, R. (2006): Insect biostratigraphy of the Euramerican continental Late Pennsylvanian and Early Permian. - In: Lucas, S. G., Cassinis, G., Schneider, J. W. (eds), Non-Marine Permian Biostratigraphy and Biochronology. Special Publications, Geological Society, London, 265: 325-336.

https://doi.org/10.1144/GSL.SP.2006.265.01.15

Schultze, H.-P. (2009): Interpretation of marine and freshwater paleoenvironments in Permo-Carboniferous deposits. - Palaeogeography, Palaeoclimatology, Palaeoecology, 281: 126-136. https://doi.org/10.1016/j.palaeo.2009.07.017

Schultze, H.-P. (2016): Scales, Enamel, Cosmine, Ganoine, and Early Osteichthyans. - Comptes Rendus Paleovol, 15: 83-102. https://doi.org/10.1016/j.crpv.2015.04.001

Schultze, H.-P., Soler-Gijón, R. (2004): A xenacanth clasper from the ?uppermost Carboniferous - Lower Permian of Buxières-les-Mines (Massif Central, France) and the palaeoecology of the European Permo-Carboniferous ba- sins. - Neues Jahrbuch für Geologie und Paläontologie, Abhandlungen, 232(2-3): 325-363.

Selezneva, A. A. (1985): Evenkia - predok Polypterus (lučeperye) [Evenkia - ancestor of Polypterus (Actinopterygii)]. - Paleontologicheskiy zhurnal, 3: 71-76. (in Russian)

Štamberg, S. (1976): Revision of genus Paramblypterus (Actimopterygii) from the Lower Permian of Bohemia. - Sborník geologických věd, Paleontologie, 18: 9-52.

Štamberg, S. (1988): Fish Spinarichthys dispersus (Actinopterygii) from the carboniferous of Bohemia. - Acta Universitatis Carolinae, Geologica, 1986(2): 155-169.

Stamberg, S. (1991): Actinopterygians of the Central Bohemian Carboniferous Basins. - Acta Musei Nationalis Pragae, Series B - Historia Naturalis, 47(1-4): 25-104.

Štamberg, S. (2007): Permo-Carboniferous Actinopterygians of the Boskovice Graben. Part 1. Neslovicella, Bourbonnella, Letovichthys, Elonichthys. - Muzeum východních Čech v Hradci Králové, Hradec Králové, 155 pp.

Štamberg, S. (2010a): Taxonomic remarks on Rhabdolepis saarbrueckensis Gardiner, 1963 (Osteichthyes: Actinopterygii) and its relationsips to some actinopterygians from the Late Carboniferous of the Bohemian Massif, Czech Republic. - Journal of the National Museum (Prague), Natural History Series, 179(15): 153-170.

Štamberg, S. (2010b): A new aeduellid actinopterygian from the Lower Permian of the Krkonoše Piedmont Basin (Bohemian Massif) and its relationship to other Aeduellidae. - Bulletin of Geosciences, 85(2): 183-198. https://doi.org/10.3140/bull.geosci.1190

Stamberg, S. (2013a): Knowledge of the Carboniferous and Permian actinopterygian fishes of the Bohemian Massif - 100 years after Antonín Frič. - Acta Musei Nationalis Pragae, Series B - Historia Naturalis, 69(3-4):159-181. https://doi.org/10.14446/AMNP.2013.159

Stamberg, S. (2013b): New data on the osteology of the actinopterygian fish Amblypterus and the relations of Amblypterus to Paramblypterus. - Acta Musei Nationalis Pragae, Series B - Historia Naturalis, 69(3-4): 183-193. https://doi.org/10.14446/AMNP.2013.183

Štamberg, S. (2016a): A new actinopterygian species of Igornichthys Heyler, 1972 from the Permian of the Krkonoše Piedmont Basin (Bohemian Massif, Czech Republic), and its relationship to the actinopterygians of other European Permo-Carboniferous basins. - Geodiversitas, 38(4): 475488. https://doi.org/10.5252/g2016n4a1

Štamberg, S. (2016b): Actinopterygians of the Stephanian sediments of the Krkonoše Piedmont Basin (Bohemian Massif) and their palaeobiogeographic relationship. Bulletin of Geosciences, 91(1): 169-186. https://doi.org/10.3140/bull.geosci.1582

Štamberg, S., Zajíc, J. (1994): Setlikia bohemica gen. et sp. nov., a new actinopterygian fish (Actinopterygii, Igornichthyidae) from the Late Carboniferous of Bohemia. Věstník Českého geologického ústavu, 69(3): 53-58.

Steyer, J. S., Esçuillié, F., Pouillon, J. M., Broutin, J., Debriette, P., Freyet, P., Gand, G., Poplin, C., Rage, J. C., Rival, J., Schneider, J. W., Štamberg, S., Werneburg, R., Cuny, G. (2000): New data on the flora and fauna from the ?uppermost Carboniferous-Lower Permian of $\mathrm{Bu}-$ xières-les-Mines, Bourbon l'Archambault Basin (Allier, 
France). A preliminary report. - Bulletin de la Société Géologique de France, 171(2): 239-249.

https://doi.org/10.2113/171.2.239

Traquair, R. H. (1866): Description of Pygopterus greenockii (Agassiz): with notes on the structural relations of the genera Amblypterus and Eurynotus. - Proceedings of the Royal Society of Edinburgh, 5: 597-599. https://doi.org/10.1017/S0370164600041481

Traquair, R. H. (1877): The ganoid fishes of the British Carboniferous formations. Part I. Palaeoniscidae. - Monographs, Palaeontographical Society, 31(140): 1-60. https://doi.org/10.1080/02693445.1877.12027943

Véran, M. (1988): Les éléments accessoires de l'arc hyoïdïen des poissons téléostomes (Acanthodiens et Osteichthyens) fossiles et actuels. - Mémoires du Muséum d'histoire naturelle, Sciences de la Terre, 54: 1-98.

Watson, D. M. S. (1928): On some points in the structure of paleoniscid and allied fish. - Proceedings of the Zoological Society of London, 1928: 49-70.

Werneburg, R. (2003): The branchiosaurid amphibians from the Lower Permian of Buxières-les-Mines, Bourbon l'Archambault Basin (Allier, France) and their biostratigraphic significance. - Bulletin de la Société Géologique de France, 174(4): 343-349.

https://doi.org/10.2113/174.4.343
Werneburg, R., Schneider, J. W. (2006): Amphibian biostratigraphy of the European Permo-Carboniferous. - In: Lucas, S. G., Cassinis, G., Schneider, J. W. (eds), NonMarine Permian Biostratigraphy and Biochronology. Special Publications, Geological Society, London, 265: 201-215. https://doi.org/10.1144/GSL.SP.2006.265.01.09

Westoll, T. S. (1937): On a remarkable fish from the Lower Permian of Autun, France. - The Annals and Magazine of Natural History, Ser. 10, 19: 553-557. https://doi.org/10.1080/00222933708655302

White, E. I. (1927): The Fish-Fauna of the Cementstones of Foulden, Berwickshire. - Transactions of the Royal Society of Edinburgh, 55: 255-287. https://doi.org/10.1017/S008045680001632X

Whiteaves, J. F. (1881): On some remarkable fossil fishes from the Devonian rocks of Scaumentac Bay, P. Q., with description of a new genus and three new species. Canadian Naturalist, N. S., 10: 27-35.

Woodward, A. S. (1906): On a carboniferous Fish Fauna from the Mansfield District, Victoria. - Memoirs of the National Museum, Melbourne, 1906(1):1-32. https://doi.org/10.24199/j.mmv.1906.1.01 